\title{
RECUPERAÇÃO DOS CRÉDITOS DO FUNDO DE GARANTIA DO TEMPO DE SERVIÇO - FGTS: REVISÃO DO ATUAL MODELO, EM BUSCA DE EFETIVIDADE
}

\begin{abstract}
Dissertação apresentada ao Departamento de Direito do Trabalho e Seguridade Social da Faculdade de Direito da Universidade de São Paulo como parte das exigências para obtenção do título de Mestre em Direito.
\end{abstract}

Orientador: Professor Titular Doutor Nelson Mannrich

Faculdade de Direito da Universidade de São Paulo

São Paulo 


\section{RESUMO}

CARBONI, Mario Augusto. Recuperação dos créditos do Fundo de Garantia do Tempo de Serviço - FGTS: revisão do atual modelo, em busca de efetividade. Dissertação de Mestrado. Faculdade de Direito da Universidade de São Paulo. São Paulo, 2011.

O presente trabalho de pesquisa tem como proposta identificar os pontos críticos e apresentar reflexões sobre o modelo jurídico de recuperação dos créditos do Fundo de Garantia do Tempo de Serviço - FGTS em face dos empregadores, tanto no âmbito da cobrança judicial envidada pelos trabalhadores, quanto no plano das cobranças administrativa e judicial promovidas pela União, considerando os interesses sociais envolvidos e as finalidades perseguidas pelos agentes da recuperação, e tendo como paradigma a compreensão do FGTS como direito fundamental do trabalhador, a exigir efetividade do modelo de recuperação dos seus créditos.

Palavras-chave: FGTS, recuperação, efetividade, direito fundamental. 


\section{ABSTRACT}

CARBONI, Mario Augusto. Brazilian's Employment Compensation Fund's credit recovery: an update of the current system and suggestions for effectiveness. Master's thesis. Faculty of Law, University of São Paulo. São Paulo, 2011.

This research aims to reflect upon and identify the difficulties connected with the recovery of debts owed to the Brazilian's Employment Compensation Fund, in Portuguese - Fundo de Garantia do Tempo de Serviço (FGTS). The focus is both in the worker's lawsuits against employers, as well as the administrative and judicial measures taken by the Federal Government through their attorneys. The recovery of the debts owed to the Fund is analyzed within the frame of worker's fundamental rights guaranteed by the Constitution, demanding effectiveness.

Keywords: FGTS, recovery, effectiveness, fundamental right. 
Para todas as coisas tenho força em virtude daquele que me confere poder. (Filipenses 4:13) 
À minha família e aos meus amigos, com carinho e gratidão, pelo apoio em todos os momentos e pela compreensão às horas furtadas ao seu convívio.

Ao meu orientador, Doutor Nelson Mannrich, pelo brilhantismo na condução dos estudos e orientações, e pela oportunidade concedida para o desenvolvimento da presente pesquisa. 


\section{SUMÁRIO}

INTRODUÇÃO

CAPÍTULO 1 - FUNDO DE GARANTIA DO TEMPO DE SERVIÇO: NOCÕES PROPEDÊUTICAS

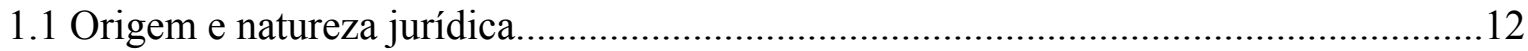

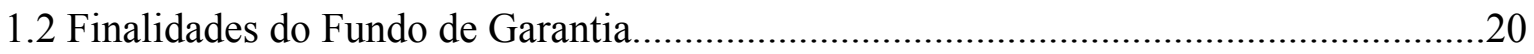

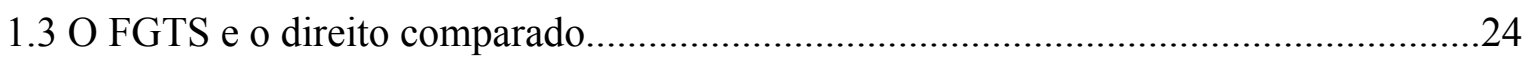

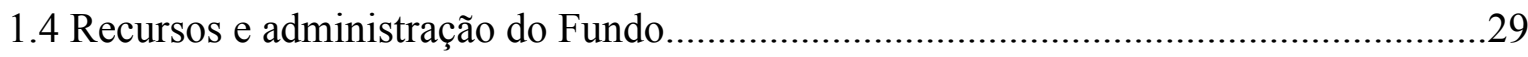

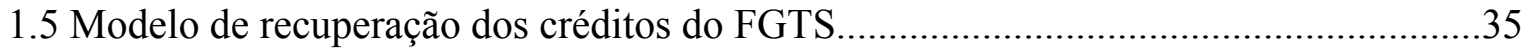

CAPÍTULO 2 - A RECUPERAÇÃO JUDICIAL DAS CONTRIBUIÇÕES DO FGTS PELO TRABALHADOR

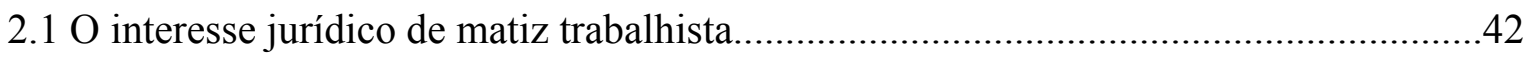

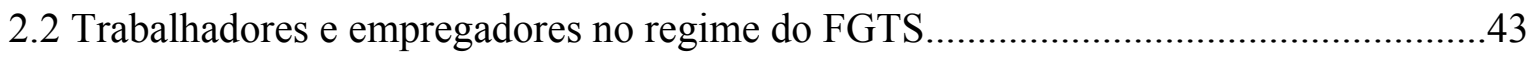

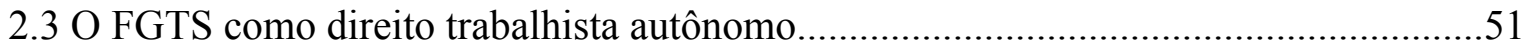

2.4 O Fundo de Garantia do Tempo de Serviço e a ação trabalhista

2.4.1 Competência da Justiça do Trabalho.

2.4.2 Estrutura processual de cobrança judicial do FGTS pelo trabalhador...............54

2.4.3 Notificação da ação trabalhista ao Poder Público.............................................61

2.5 Prescrição trintenária e a Justiça do Trabalho..................................................................64 


\section{CAPÍTULO 3 - A RECUPERAÇÃO ADMINISTRATIVA DOS CRÉDITOS DO FGTS}

PELA UNIÃO

3.1 Identificação dos interesses jurídicos 74

3.2 FGTS como objeto de ação fiscal no âmbito do Ministério do Trabalho e Emprego... 75

3.3 Notificações de débitos relacionados aos depósitos vinculados mensais e rescisórios

3.3.1 Verificação do recolhimento e levantamento de débitos do FGTS .82

3.3.2 Individualização dos trabalhadores titulares dos créditos do FGTS 88

3.4 Autuações quanto às infrações e penalidades administrativas do Fundo de Garantia...90

3.5 Defesa do empregador em face das notificações de recolhimento e auto de infração relativos ao FGTS. .93

\section{CAPÍTULO 4 - A RECUPERAÇÃO JUDICIAL DOS CRÉDITOS DO FGTS PELA UNIÃO}

4.1 Interesse jurídico de cunho econômico-social .98

4.2 Créditos do FGTS como objeto de execução físcal

4.2.1 Representação judicial e extrajudicial do FGTS 100

4.2.2 Créditos relacionados às penalidades administrativas e a Justiça do Trabalho 105

4.2.3 Créditos relacionados aos depósitos vinculados mensais e rescisórios e a Justiça Federal. 110

4.3 Reflexos na execução do pagamento direto ao trabalhador dos créditos do FGTS em ação trabalhista. 


\section{INTRODUÇÃO}

\section{Problemática e delimitação do tema a ser desenvolvido}

A construção do conhecimento científico advém da dúvida, de uma inquietação em face da realidade vivenciada, o que metodologicamente denomina-se de problema de pesquisa.

A inquietação da realidade jurídica a ser investigada na presente pesquisa encontra-se no atual modelo de recuperação dos créditos devidos pelos empregadores ao Fundo de Garantia do Tempo de Serviço - FGTS, correspondente às contribuições mensais e rescisórias, e multas punitivas aplicadas pela fiscalização do trabalho, especificamente no que tange aos interesses sociais perseguidos e aos efeitos produzidos em relação à satisfação do trabalhador como sujeito titular do direito fundamental relativo ao Fundo de Garantia do Tempo de Serviço, na esteira da diçcão do artigo 7. ${ }^{\circ}$, III da Constituição Federal.

O instituto do FGTS, sob a ótica da sua gama de recursos, apresenta uma natureza tridimensional, a qual encerra um complexo de relações jurídicas e obrigações distintas.

De um lado existe o vínculo entre as partes da relação de trabalho, conforme se extrai do artigo 15 da Lei 8.036/90, o qual cria para o empregador, dentre outros, o dever principal de efetuar recolhimentos mensal e rescisório da contribuição ao FGTS em conta vinculada, aberta junto à Caixa Econômica Federal, em nome do empregado. Desse vínculo surge para o empregado o direito subjetivo de instar o empregador ao cumprimento da obrigação de efetuar os depósitos mensais e ou rescisório em sua conta vinculada.

De outro lado há o vínculo entre a União e o empregador. Esse vínculo decorre de lei e encerra o poder estatal de fiscalizar o cumprimento das obrigações impostas ao empregador pela legislação de regência do FGTS, de aplicar as penalidades e 
sanções correspondentes na hipótese de inobservância dos deveres legais, e também de arrecadar os depósitos mensais e rescisórios, bem como promover a cobrança administrativa e judicial dos respectivos créditos em face dos empregadores.

Por fim, existe o vínculo entre a União e o empregado no que tange ao controle e remuneração das contas vinculadas, além da liberação dos recursos ao trabalhador nas hipóteses legais, como atividades confiadas à Caixa Econômica Federal, empresa pública com atribuição de agente operador dos recursos do FGTS.

Da análise do Fundo de Garantia do Tempo de Serviço sob o ponto de vista tridimensional dos vínculos apontados, contatam-se, na realidade fenomênica, controvérsias nas três vertentes consideradas com relação à entrada e a saída de recursos financeiros do Fundo.

Os limites da investigação científica proposta cingem-se aos dois primeiros vínculos apontados, como configuradores do atual modelo de recuperação dos créditos decorrentes das contribuições devidas pelo empregador ao FGTS, relativos aos depósitos vinculados mensais e rescisórios, bem como às multas administrativas aplicadas pela fiscalização do trabalho em face do descumprimento das regras legais do Fundo.

As figuras do empregado e da União como legitimados para a cobrança das contribuições relativas ao FGTS devidas pelos empregadores demanda investigação sobre as finalidades do Fundo, que podem ser desdobradas numa faceta trabalhista, configurada pelo crédito compensatório do tempo de serviço do trabalhador para albergá-lo diante de contingências legalmente previstas e servir como regime de indenização por sua dispensa arbitrária ou sem justa causa, bem como numa faceta econômico-social, identificada pelo financiamento de programas sociais de habitação, saneamento básico e infraestruturas urbana e de base, promotores do desenvolvimento nacional e da geração de empregos.

Considerada a relação entre trabalhador e empregador, o processo para recuperação dos valores devidos ao FGTS se dá por meio das ações judiciais trabalhistas promovidas perante a Justiça do Trabalho, tendo como autor o empregado, e como réu o empregador, nos termos do artigo 25, da Lei 8.036/90, e do artigo 114, I, da Constituição Federal. 
De outro lado, considerado o vínculo entre o empregador e a União, o processo de recuperação dos créditos do FGTS desdobra-se numa fase administrativa seguida de uma fase judicial de cobrança.

$\mathrm{Na}$ fase administrativa, a fiscalização do Ministério do Trabalho e Emprego ao constatar a ausência de recolhimento ou recolhimento a menor das contribuições mensais ou rescisórias relativas ao FGTS emite notificação fiscal a fim de que o empregador recolha a importância apurada como devida, a ser individualizada para cada trabalhador.

Não ocorrendo recolhimento ou individualização dos créditos pelo empregador fiscalizado será lavrado auto de infração e aplicada a penalidade correspondente, nos termos do artigo 23, da Lei 8.036/90, podendo o empregador discutir administrativamente o Auto de Infração e as subjacentes notificações fiscais. Após confirmados administrativamente o auto de infração e as notificações fiscais, o crédito do FGTS será inscrito em dívida ativa da União pela Procuradoria-Geral da Fazenda Nacional.

Ocorre que a inscrição em dívida e a recuperação judicial dos créditos do FGTS perfazem-se de forma dicotômica em relação ao auto de infração e às notificações fiscais de recolhimento emitidas pela autoridade administrativa do trabalho. Com efeito, os valores devidos pelo empregador ao Fundo de Garantia relativos aos depósitos mensais ou rescisórios são perseguidos pela União perante órgão da Justiça Federal, segundo entendimento firmado pela Súmula 349, do Superior Tribunal de Justiça, com base no artigo 109, I da Constituição Federal. Ao passo que os créditos decorrentes das multas administrativas aplicadas pela fiscalização do trabalho por descumprimento das regras do Fundo são cobrados pela União perante órgão da Justiça do Trabalho, segundo artigo 114, VII, da Constituição Federal, incluído pela Emenda Constitucional nº 45/2004.

O objetivo geral deste trabalho é compreender a realidade do modelo de recuperação dos créditos devidos pelos empregadores ao Fundo de Garantia do Tempo de Serviço e revelar os distintos interesses do atual modelo em cotejo com as finalidades legais e constitucionais do Fundo de Garantia, identificando as inconsistências que interferem na sua concretização como direito social fundamental do trabalhador. 
Em face do objetivo geral, primeiramente cumprirá a pesquisa o mister de aprofundar considerações sobre o cenário da recuperação dos créditos do FGTS empreendida pelo trabalhador, cujo processo litigioso de cobrança ocorre por meio das ações trabalhistas, com reflexões sobre os pontos críticos que impactam negativamente na sua efetividade.

Posteriormente, passa-se à analise do processo de recuperação dos créditos do FGTS promovida pela União, nas fases administrativa e judicial, com apontamento crítico de questões que refletem na sua efetividade, especialmente no que tange à dicotomia do modelo de cobrança perante a Justiça Federal e a Justiça do Trabalho.

Os pilares das reflexões e apontamentos da presente pesquisa são as finalidades do Fundo de Garantia do Tempo de Serviço, os interesses sociais envolvidos e a necessidade de se evitar competência concorrente entre os ramos do Poder Judiciário, para prevenir a ocorrência de decisões conflitantes e insegurança jurídica. Para tanto, no decorrer do trabalho perscrutam-se possíveis elementos que possam denotar inconsistência do sistema e desafiar a efetividade do modelo de recuperação dos créditos do FGTS referentes às contribuições mensais e rescisórias e às multas aplicadas ao empregador pela fiscalização do trabalho, erigida como paradigma a compreensão do Fundo de Garantia do Tempo de Serviço como direito fundamental do trabalhador.

\section{Justificativa da escolha e da importância do tema}

Apresentam-se como justificativas para a escolha do tema desta pesquisa sua atualidade no contexto sócio-jurídico, sua relevância social e doutrinária, aliadas à necessidade de reflexões sobre tema pouco explorado pela literatura jurídica nacional.

Reputa-se o tema de pesquisa como de alta relevância jurídico-científica, com reflexos social e político, por identificar problemas pragmáticos e apresentar proposição de soluções que garantam a efetividade do modelo de recuperação dos créditos relativos ao FGTS devidos pelos empregadores, o qual se insere na esteira da preservação da higidez do Fundo para fazer face às suas finalidades trabalhistas e sociais. 
Para se ter uma dimensão da necessidade de um modelo hígido e eficiente de recuperação dos créditos do FGTS, basta tomar dados da realidade, que segundo um levantamento feito pela Caixa Econômica Federal ${ }^{1}$ em 2010, demonstram que as dívidas dos empregadores com o pagamento do Fundo de Garantia do Tempo de Serviço, somam $\mathrm{R} \$ 12,8$ bilhões no país, em um total de 330.243 mil ações em cobrança desde a década de 60, quando o benefício foi criado, sendo que 34.523 ações são administrativas e mais 295.720 são judiciais. Desse total, somente cerca de 9.354 dívidas estão sendo pagas aos trabalhadores, por meio de parcelamentos do valor devido.

Por fim, o interesse na escolha do presente tema está aliado à atuação profissional do pesquisador como membro efetivo da Procuradoria-Geral da Fazenda Nacional, a qual detém a representação judicial e extrajudicial do FGTS para promover a correspondente cobrança dos créditos relativos às contribuições e às multas e demais encargos previstos na legislação respectiva.

\section{Metodologia}

No âmbito da metodologia e técnica de pesquisa adotadas, cumpre esclarecer que foi realizado levantamento bibliográfico sobre os estudos e linhas de pensamento existentes sobre o tema, legislação pertinente, direito comparado e outras ciências inseridas na problemática, tais como estudos de história e sociologia. A pesquisa pautou pela utilização da dogmática jurídica, e dos métodos dialético, dedutivo-indutivo, de comparação e histórico, para examinar o fenômeno jurídico contextualizado no tempo.

As fontes utilizadas no desenvolvimento do trabalho foram: a legislação, vista de uma forma geral e específica; a pesquisa bibliográfica nacional e estrangeira; os estudos desenvolvidos por órgãos e entidades ligados ao assunto; a pesquisa da tendência jurisprudencial nacional; a pesquisa histórica; e a consulta e interface com órgãos públicos relacionados ao tema.

\footnotetext{
${ }^{1}$ Disponível em http://www.caixa.gov.br/fgts. Acesso em: 06.01.2011.
} 


\section{CAPÍTULO 1. FUNDO DE GARANTIA DO TEMPO DE SERVIÇO: NOÇÕES PROPEDÊUTICAS}

\subsection{Origem e natureza jurídica}

Inicialmente a legislação trabalhista garantia a estabilidade do trabalhador no emprego após dez anos de efetivo serviço para o mesmo empregador, consoante disciplinado pelos artigos 492 e seguintes, da Consolidação das Leis do Trabalho (CLT).

Assim, o empregado com estabilidade decenal não poderia ser dispensado, exceto se cometesse uma falta grave, enquadrada em alguma das hipóteses do artigo 482, da CLT, e desde que tal falta fosse objeto de apuração por meio de inquérito judicial proposto na Justiça do Trabalho. Caso houvesse dispensa antes de ter completado este período, o trabalhador tinha direito a uma indenização compensatória.

A criação do Fundo de Garantia do Tempo de Serviço - FGTS pela Lei 5.107, de 13 de setembro de 1966, num contexto de reformas estruturais, foi um dos instrumentos encontrados pelo Estado para flexibilizar o regime de dispensas no país, em substituição à estabilidade decenal garantida por lei, possibilitando, na linguagem contábil, a desoneração das empresas do passivo representado pelos contratos de trabalho com mais de dez anos em execução.

O discurso proferido pelo então Presidente da República, Humberto de Alencar Castelo Branco, na Assembléia Legislativa de Minas Gerais, no dia 28 de fevereiro de 1966, revela o panorama econômico e social que levou à instituição do FGTS. O discurso deu-se nos seguintes termos: 
Burlado pelos patrões e deformado pela escassa minoria dos trabalhadores que o alcançam, o instituto da estabilidade tornou-se um autêntico instituto de inquietação. A situação atual estimula o empregador a usar artifícios e a buscar, de qualquer modo, a dispensa por justa causa a fim de se livrar do ônus latente, ou, a evitar que o empregado atinja os dez anos, o indenizando antes de completar esse tempo, pelo receio de indisciplina e descaso pela produtividade do trabalhador que atinge a estabilidade. ${ }^{2}$

O objetivo econômico da instituição do FGTS foi de gerar a flexibilização ${ }^{3}$ do mercado de trabalho e proporcionar às empresas maior autonomia em suas políticas de recursos humanos, com redução dos custos de dispensas e aumento da produtividade da mão-de-obra empregada, uma vez que, na visão empresarial, o empregado, após dez anos de serviços prestados, ao adquirir a estabilidade, tornava-se menos produtivo e mais oneroso.

A partir dessa perspectiva, o FGTS passa a possibilitar maior dinâmica ao mercado de trabalho, com a redução dos riscos e custos de longo prazo das empresas ao contratarem empregados. Ao mesmo tempo o FGTS serve de amparo ao trabalhador, eis que na eventualidade de perda do emprego, e outras contingências, previu-se a possibilidade de levantar os valores pecuniários acumulados no Fundo em seu nome. Assim, o FGTS passou a oferecer ao trabalhador, em troca da estabilidade no emprego ${ }^{4}$, a possibilidade de formar um patrimônio, proporcionando, dentre outras hipóteses legais, o financiamento da aquisição da casa própria com o saldo do Fundo.

Esclarecedoras são as lições de Roberto Barreto Prado, que em escritos da ocasião da instituição do regime do Fundo de Garantia do Tempo de Serviço, assevera que a substituição do direito de estabilidade decenal pelo instituto do FGTS melhor assegura a gestão da empresa pelo empregador e incentiva o trabalho associativo, em consonância com a mentalidade jurídica dominante no pais. $\mathrm{O}$ autor distingue os conceitos de reparação de danos, decorrentes da perda do emprego, e o direito de receber assistência do Fundo de Garantia, afirmando que a primeira medida é imprescindível para solucionar o

\footnotetext{
${ }^{2}$ SAAD, Eduardo Gabriel. Lei do Fundo de Garantia do Tempo de Serviço. São Paulo: LTr, 1969, p. 10.

${ }^{3}$ Pode-se entender flexibilização das normas trabalhistas como "processo relacionado com a adaptação dos preceitos que regulamentam as relações laborais às grandes alterações ditadas por fatores diversos que afetam a nova realidade do mundo do trabalho". In BELTRAN, Ari Possidonio. Dilemas do trabalho e do emprego na atualidade. São Paulo: LTr, 2001, p. 149.

${ }^{4}$ Interessante é a proposta de Roberto Santos quanto à alíquota regressiva do FGTS para estimular a empresa a reter empregados, atribuindo ao regime do FGTS uma natureza compensatória do tempo de serviço e ao mesmo tempo um mecanismo de incentivo à manutenção do emprego. In ROMITA, Arion Sayão (Org.). Curso de Direito do Trabalho: homenagem a Evaristo de Moraes Filho. São Paulo: LTr, 1983, p. 407/408.
} 
problema social, pois assegura o efetivo recebimento das indenizações devidas por dispensa, possibilitando ao trabalhador um mínimo de tranquilidade e conforto, ao passo que, concomitantemente, possibilita ao trabalhador "o direito de se beneficiar $d a$ importância depositada em sua conta vinculada, nos casos restritos que digam respeito às suas necessidades prementes, de natureza pessoal ou familiar". 5

Ao lado das garantias deferidas ao trabalhador, a legislação instituidora do FGTS também estabeleceu a finalidade de utilização de seus recursos para o financiamento de programas de habitação popular, saneamento básico e infraestrutura urbana.

O regime do FGTS era opcional e alternativo ao regime da estabilidade decenal, situação que perdurou até a promulgação da Constituição de 1988, a qual elencou o fundo de garantia como direito social fundamental do trabalhador e o tornou obrigatório como sistema único a toda relação de emprego.

Após a Constituição Federal de 1988, o FGTS foi regulado pela Lei 7.839/89, a qual teve um curto período de vigência, eis que revogada pela Lei 8.036/90, a atual legislação de regência do Fundo.

Abordada a origem do FGTS, impende tecer algumas linhas basilares sobre o seu conceito e natureza jurídica.

A partir do texto legal extrai-se que o Fundo de Garantia do Tempo de Serviço é uma massa de recursos sem personalidade jurídica própria. José Augusto Rodrigues Pinto assevera que o FGTS representa uma plêiade de depósitos de responsabilidade dos empregadores, em razão de suas relações individuais de emprego, em contas bancárias de que são titulares os empregados, destinada à formação de um patrimônio retributivo da energia investida em favor da empresa, com movimentação ou saques vinculados especificamente às hipóteses previstas em lei ${ }^{6}$.

Convém destacar que o FGTS não se confunde com indenização, pois esta visa ao ressarcimento pelo dano causado pelo empregador ao empregado, em razão da

\footnotetext{
${ }^{5}$ PRADO, Roberto Barreto. Tratado de Direito do Trabalho. vol. II. São Paulo: Editora RT, 1971, p. 637.

${ }^{6}$ PINTO, José Augusto Rodrigues. Curso de Direito Individual do Trabalho. São Paulo: LTr, 1995. p. 472.
} 
perda do emprego ${ }^{7}$, ao passo que o FGTS veio substituir o sistema de estabilidade, e apresenta natureza compensatória do tempo de serviço do empregado na empresa ${ }^{8}$. De todo modo, a partir de 1988, por mandamento do artigo 10, I, do Ato das Disposições Constitucionais Transitórias, o FGTS passou a supedâneo da indenização pela perda do emprego, pois diante da dispensa arbitrária ou sem justa causa é devido ao trabalhador o valor correspondente a $40 \%$ (quarenta por cento) calculado sobre os depósitos do Fundo de Garantia em sua conta vinculada referente à relação de emprego, com nítida natureza indenizatória ${ }^{9}$.

Diante do regramento legal do FGTS, e partindo-se da fixação do conceito que leva em conta sua finalidade trabalhista de garantia do tempo de serviço do trabalhador, é possível identificá-lo como um instituto caracterizado por uma massa de recursos formada por depósitos prévios dos empregadores e outros recursos incorporados previstos pela legislação, que propicia acúmulo de valores em conta vinculada de cada trabalhador, servindo-lhe como crédito compensatório do seu tempo de serviço para albergá-lo diante de contingências legalmente previstas e como regime de indenização por dispensa arbitrária ou sem justa causa.

A conceituação do FGTS não passa ao largo da busca de sua natureza jurídica. Entretanto, essa não é uma tarefa fácil, e para os objetivos da presente pesquisa basta a apresentação das principais teorias a respeito do tema para subsidiar as reflexões.

A doutrina não é uníssona em determinar a natureza jurídica dos recursos do FGTS, havendo diversas teorias que buscam revelá-la.

Em estudo sobre o tema, Sérgio Pinto Martins ${ }^{10}$ conclui que a identificação da natureza jurídica do FGTS deve ser analisada sob dois ângulos, o da sua relação com o empregado, e o da sua relação com o empregador, o que leva à conclusão de sua natureza híbrida ou múltipla, conclusão a que chega também Amauri Mascaro Nascimento ${ }^{11}$.

\footnotetext{
${ }^{7}$ MAGANO, Octavio Bueno. Primeiras lições de Direito do Trabalho. $3^{\text {a }}$ ed. São Paulo: RT, 2003, p. 85. ${ }^{8}$ MARTINS, Sérgio Pinto. Manual do FGTS. São Paulo: Atlas, 2006, p. 37.

${ }^{9}$ DONATO, Messias Pereira. Curso de Direito Individual do Trabalho. 6 a ed. São Paulo: LTr, 2008, p. 729.

${ }^{10}$ MARTINS, Sérgio Pinto. Ibid. p. 61.

${ }^{11}$ NASCIMENTO, Amauri Mascaro. Iniciação ao Direito do Trabalho. $34^{\mathrm{a}}$ ed., São Paulo: LTr, 2009, p. 345 .
} 
No que concerne à relação entre o empregado e os recursos do FGTS há a teoria que os considera como salário diferido, salário social ou socializado devido pela sociedade ao trabalhador, indenização semipública por responsabilidade objetiva do tipo risco social, crédito-compensação do tempo de serviço do empregado, e fundo contábil de reserva ou provisão legal em face de contingências.

Pela teoria do salário diferido ${ }^{12}$, tem-se que os depósitos efetuados pelo empregador na conta vinculada do empregado configuram salário adquirido no presente, que será utilizado no futuro. Assim, parte do salário do empregado não é paga diretamente ao obreiro, mas destinada ao fundo, com vistas à formação de saldo de recursos que no futuro proverá a subsistência do empregado na hipótese de ocorrência dos eventos ou causas legalmente previstas como autorizadoras do levantamento dos valores depositados. Assim, o salário é diferido porque o benefício não é pago imediatamente ao empregado, mas em momento futuro.

Por sua vez, quanto a teoria do salário social ou socializado, segundo Pierre Ollier ${ }^{13}$, pode ser identificado desenvolvimento progressivo do salário, que se transmuda de uma concepção individual para uma concepção social. Assim, o salário não é pago apenas quando há trabalho, sendo que de salário direto, pago pelo empregador, passase a salário indireto, pago por órgão social diante de certos eventos de inatividade. Nessa visão, o salário seria devido também pela sociedade ao trabalhador.

Noutro âmbito de considerações, a teoria do FGTS como indenização semipública considera que os valores liberados ao trabalhador pelo Fundo decorrem de responsabilidade objetiva do tipo risco social, sendo crédito vinculado que somente poderá ser liberado nas hipóteses previstas em lei. É direito subjetivo social do trabalhador. Entende Elson Gottschalk ${ }^{14}$ que o deslocamento da indenização para conta vinculada do empregado, e às vezes, para conta vinculada da empresa constitui, em essência, a passagem do princípio indenizatório do Direito privado para o Direito público, ou seja, a transferência da obrigação de indenizar baseada na culpa subjetiva para obrigação de indenização baseada na culpa objetiva ou risco social.

\footnotetext{
${ }^{12}$ SÜSSEKIND, Arnaldo; MARANHÃO, Délio; VIANNA, Segadas; TEIXEIRA, Lima. Instituições de direito do trabalho. $19^{\mathrm{a}}$ ed. São Paulo: LTr., 2002, p. 644.

${ }_{13}^{13}$ OLLIER, Pierre. Le droit du travail. Paris: Armand Colin, 1972, p.173.

${ }^{14}$ GOTTSCHALK, Elson. Natureza jurídica da indenização da lei do FGTS. In Revista LTr 38/819, São Paulo: LTr, p. 805.
} 
De seu turno, Amaro Barreto explica que a natureza do FGTS é de crédito-compensação, em razão da colaboração prestada pelo empregado à empresa, por meio do tempo de serviço despendido ${ }^{15}$.

Já, pela teoria do fundo contábil ${ }^{16}$, atribui-se ao FGTS a função de canalização do produto de sua arrecadação para abastecer de recursos fundo de natureza contábil, destinado à provisão legal do trabalhador em face de contingências.

Inobstante as discussões doutrinárias de que se ocupam as teorias apontadas, na relação entre o FGTS e o empregado, para os fins do presente trabalho, adota-se como referencial a consagração e finalidade constitucional trabalhista do fundo.

Nesse sentido, os recursos do FGTS devem ser tidos como créditos compensatórios do tempo de serviço do obreiro, e como sistema que dá suporte à indenização por dispensa arbitrária ou sem justa causa, substitutivo da estabilidade decenal, e assim, o Fundo de Garantia apresenta natureza de direito fundamental do trabalhador, na forma determinada pelo artigo $7 .^{\circ}$, III, da Constituição Federal de 1988, o qual dispõe que:

Artigo 7. ${ }^{\circ}$ São direitos dos trabalhadores urbanos e rurais, além de outros que visem à melhoria de sua condição social: (...)

III - fundo de garantia do tempo de serviço; (...)

De outro lado, também são diversas as teorias jurídicas que se ocupam de explicar a natureza jurídica dos recursos do FGTS em sua relação com o empregador, no que tange à obrigação principal de realizar o depósito mensal ou rescisório na conta vinculada do empregado.

Nesse diapasão podem ser citadas: a teoria da indenização, que enxerga nos depósitos a substituição das indenizações de antiguidade do empregado ${ }^{17}$; a teoria do tributo, a qual propugna a obrigação de depósito como contribuição social de intervenção no domínio econômico, adaptada perfeitamente no artigo $3 .^{\circ}$ do Código Tributário Nacional; a teoria da contribuição previdenciária, segundo a qual identificam-se

\footnotetext{
${ }^{15}$ BARRETO, Amaro. Teoria e prática do FGTS. São Paulo: Edições Trabalhistas, 1974, p. 48.

${ }^{16}$ OLIVEIRA, Fábio Leopoldo de. Curso expositivo de direito do trabalho. São Paulo: LTr, 1991, p. 185.

${ }^{17}$ NASCIMENTO, Amauri Mascaro. Iniciação ao direito do trabalho. Op. cit., p. 125.
} 
semelhanças entre as finalidades do Fundo de Garantia e as finalidades do sistema previdenciário $^{18}$; além das teorias do salário diferido, da indenização semipública e do crédito-compensação.

Merecem considerações a teoria do FGTS como tributo, sintetizada pela doutrina jurídica ${ }^{19}$ com fulcro no artigo 3. ${ }^{\circ}$ do Código Tributário Nacional - CTN, segundo o qual tributo "é toda prestação pecuniária compulsória, em moeda ou cujo valor nela se possa exprimir, que não constitua sanção de ato ilícito, instituída em lei e cobrada mediante atividade administrativa plenamente vinculada". Assim, identifica-se a contribuição para o FGTS como compulsória, instituída por lei, a qual não constitui sanção de ato ilícito, é cobrada mediante atividade plenamente vinculada, e se enquadra no regime jurídico das contribuições sociais de intervenção no domínio econômico, destinada a financiar o desenvolvimento econômico no setor habitacional, de saneamento e de infraestrutura urbana, e de compensar o tempo de serviço do trabalhador. A teoria em exame apega-se também ao disposto no inciso IV, do artigo 217, do CTN, segundo o qual as disposições do Código Tributário Nacional não excluem a incidência e a exigibilidade da contribuição destinada ao Fundo de Garantia do Tempo de Serviço.

Segundo a teoria em análise, considerando-se o liame entre o FGTS e o empregador como relação jurídica tributária, tem-se configurados os aspectos da regra matriz de incidência tributária, de forma que o sujeito ativo é a União, o sujeito passivo é o empregador, o fato gerador é o pagamento de remuneração ao trabalhador, a base de cálculo é o valor da remuneração legalmente considerada e a alíquota é de $8 \%$ para as contribuições mensais, e 40\% para as rescisórias, cuja base de cálculo é o saldo da conta vinculada.

Sem adentrar no mérito de cada uma das teorias mencionadas resta evidente, seja sob o ângulo do trabalhador, seja sob o ângulo do empregador, que os créditos do FGTS apresentam natureza de contribuições de natureza social e trabalhista, especialmente diante do comando do citado artigo 7. $^{\circ}$, III da Constituição Federal.

De se registrar que a jurisprudência do Supremo Tribunal Federal já havia firmado entendimento neste sentido, por meio do julgamento do RE 100.249/SP,

\footnotetext{
${ }^{18}$ SAAD, Eduardo Gabriel. Comentários à Lei do Fundo de Garantia do Tempo de Serviço. São Paulo: LTr, 1995, p. 283
} 
ocorrido sob a égide do ordenamento constitucional anterior, conforme abaixo:

\begin{abstract}
As contribuições para o FGTS não se caracterizam como crédito tributário ou contribuições a tributo equiparáveis. Sua sede esta no artigo 165, XIII, da Constituição. Assegura-se ao trabalhador estabilidade, ou fundo de garantia equivalente. Dessa garantia, de índole social, promana, assim, a exigibilidade pelo trabalhador do pagamento do FGTS, quando despedido, na forma prevista em lei. Cuida-se de um direito do trabalhador. Dá-lhe o Estado garantia desse pagamento. A contribuição pelo empregador, no caso, deflui do fato de ser ele o sujeito passivo da obrigação, de natureza trabalhista e social, que encontra, na regra constitucional aludida, sua fonte. A atuação do Estado, ou de órgão da administração pública, em prol do recolhimento da contribuição do FGTS, não implica torná-lo titular do direito à contribuição, mas, apenas, decorre do cumprimento, pelo Poder Público, de obrigação de fiscalizar e tutelar a garantia assegurada ao empregado optante pelo FGTS. Não exige o Estado, quando aciona o empregador, valores a serem recolhidos ao Erário, como receita pública. Não há, daí, contribuição de natureza fiscal ou parafiscal. Os depósitos do FGTS pressupõem vínculo jurídico, com disciplina no direito do trabalho. Não se aplica às contribuições do FGTS o disposto nos arts. 173 e 174, CTN. Recurso extraordinário conhecido, por ofensa ao artigo 165, XIII, da Constituição, e provido, para afastar a prescrição quinquenal da ação ${ }^{20}$. (grifado)
\end{abstract}

\begin{abstract}
Alerta-se sobre a necessidade de atualização dos dispositivos constitucionais citados na ementa acima, considerando as atuais disposições da Constituição Federal de 1988.
\end{abstract}

Frise-se ainda, que o entendimento acima sufragado não foi alterado pelo Pleno do Supremo Tribunal Federal, pois quando do julgamento do RE 226.855/RS, assentou-se a natureza estatutária do FGTS, sob o argumento de que decorre de lei e é disciplinado por suas disposições.

No mesmo sentido a doutrina juslaboralista nacional reconhece a natureza jurídica múltipla do Fundo de Garantia do Tempo de Serviço em face dos diferentes ângulos de sua estrutura, eis que foi instituído como novo regime de indenização por dispensa sem justa causa, e também forma um pecúlio para o trabalhador. De todo modo, aponta-se a prevalência do FGTS como um instituto de natureza trabalhista, pois, visto de modo global e pelos seus aspectos preponderantes, o Fundo de Garantia é um instituto de natureza trabalhista com tendência a expandir-se para o âmbito maior ${ }^{21}$.

Dessa forma, independente das diversas teorias que explicam a natureza

\footnotetext{
${ }^{19}$ MARTINS, Sérgio Pinto. Manual do FGTS. Op. cit., p. 56/61.

${ }^{20}$ STF, Tribunal Pleno, RE 100.2490/SP, Rel. Min. Néri da Silveira, DJ 1. ․7.1988.

${ }^{21}$ NASCIMENTO, Amauri Mascaro. Iniciação ao Direito do Trabalho. Op. cit., p. 374.
} 
jurídica do Fundo de Garantia do Tempo de Serviço sob seus múltiplos ângulos, seja como salário diferido, como pecúlio, como tributo ou indenização de dispensa, sua origem as converge para um âmbito de consideração superior, como direito fundamental ${ }^{22}$ do trabalhador, chancelado pelo Constituinte de 1988, por meio do disposto no artigo $7^{\circ}$, III da Constituição da República Federativa do Brasil.

\subsection{Finalidades do Fundo de Garantia}

A exata identificação das finalidades do Fundo de Garantia do Tempo de Serviço é questão essencial que deve ficar bem delimitada para os fins do presente trabalho, pois está diretamente relacionada ao modelo de recuperação de seus créditos.

A abordagem sobre a origem e as teorias a respeito da natureza jurídica do FGTS, conforme acima expostas, somente se completa na medida de sua fundamentação sob o prisma das finalidades do Fundo.

Otávio Bueno Magano ao conceituar o FGTS leva em consideração as suas finalidades, pois afirma que é um conjunto de contas e valores, cuja finalidade consiste em assegurar a compensação do tempo de serviço prestado pelo trabalhador a uma ou mais empresas e propicia recursos para a realização da política pública habitacional ${ }^{23}$.

As finalidades do Fundo de Garantia do Tempo de Serviço estão intimamente relacionadas à destinação dada aos seus recursos. Assim, as finalidades do FGTS e correspondentes destinações dos seus recursos podem ser desdobradas numa face individual trabalhista, configurada pelo crédito compensatório do tempo de serviço do trabalhador para albergá-lo diante de contingências legalmente previstas e servir como

\footnotetext{
22"Pode-se definir direitos fundamentais como os que, em dado momento histórico, fundados no reconhecimento da dignidade da pessoa humana, asseguram a cada homem as garantias de liberdade, igualdade, solidariedade, cidadania e justiça". In ROMITA, Arion Sayão. Direitos fundamentais nas relações de trabalho. São Paulo: LTr, 2005, p. 36.
} 
regime de indenização por sua dispensa arbitrária ou sem justa causa, bem como numa faceta econômico-social, identificada pelo financiamento de programas sociais de habitação, saneamento básico e infraestruturas urbana e de base, promotores do desenvolvimento nacional e da geração de empregos.

Nesse sentido, Arnaldo Süssekind entende que, individualmente considerado, o FGTS é um crédito trabalhista que resulta de uma poupança forçada legalmente imposta ao trabalhador, a qual foi concebida para albergá-lo em situações excepcionais durante a vigência do vínculo de emprego ou na sua cessação. De outro lado, considerando-se coletivamente, a aplicação dos recursos do FGTS destina-se a financiar a construção de habitações populares, obras de saneamento básico e de infraestrutura urbana $^{24}$.

No âmbito econômico-social, o FGTS tem sido de enorme relevância no atual ciclo de desenvolvimento do país, fase caracterizada pela combinação entre crescimento econômico e geração de oportunidades de emprego e renda.

O Fundo torna possível, por exemplo, a implementação de políticas públicas nos setores de habitação e de saneamento, com a expansão dos investimentos aplicados e dos subsídios concedidos.

Outro exemplo do viés econômico-social do FGTS é o Fundo de Investimentos do FGTS (FI-FGTS), criado pela Lei no 12.087, de 11 de novembro de 2009, que definiu que os recursos atrelados ao resultado financeiro obtido pelo FGTS no exercício anterior, são destinados a investimentos realizados em obras de infraestrutura de base, permitindo o direcionamento de recursos a segmentos fundamentais como os de portos, ferrovias e geração de energia.

Sem dúvidas, tal iniciativa contribui decisivamente para a consolidação dos investimentos de longo prazo, que são essenciais para o desenvolvimento nacional e geração de empregos, eis que a viabilização de um grande volume de obras promove um efeito adicional grandioso na capacidade do país para gerar emprego e renda aos seus cidadãos.

\footnotetext{
${ }^{23}$ MAGANO, Otávio Bueno. Manual de Direito Individual do Trabalho. São Paulo: LTr, 1986, p. 314.

${ }^{24}$ SÜSSEKIND, Arnaldo; MARANHÃO, Délio; VIANNA, Segadas; TEIXEIRA, Lima. Instituições de direito do trabalho. Op. cit., p. 664.
} 
Segundo dados disponibilizados pelo portal eletrônico do FGTS ${ }^{25}$, em 2009, os recursos pagos aos trabalhadores pelos saques efetuados e os valores desembolsados do Fundo alcançaram um total de R \$ 72,7 bilhões, montante que ajudou a impulsionar o desenvolvimento do Brasil nos mais diversos campos.

Fixada a relevância e potencial do FGTS para geração de benefícios nas áreas de habitação, saneamento básico e infraestrutura urbana, sobreleva evidenciar sua faceta trabalhista, configurada pelo crédito compensatório do tempo de serviço do trabalhador para albergá-lo diante de contingências legalmente previstas e servir como regime de indenização por sua dispensa arbitrária ou sem justa causa, tomada como pilar fundamental da criação do FGTS ao substituir a estabilidade decenal do empregado.

Sob a ótica justrabalhista, o fomento de políticas públicas sociais não é finalidade primária do Fundo de Garantia do Tempo de Serviço.

Nesse sentido alerta Fabiano Jantaia que não seria correto admitir que a aplicação dos recursos, concebida de forma acessória ao verdadeiro objetivo do FGTS, influenciasse na construção do conceito e mesmo da natureza do instituto, sob pena de um resultado final que mudaria conforme o tempo e a discricionariedade de seus administradores ${ }^{26}$.

Dessa forma, sob a ótica juslaboralista o FGTS é um direito constitucional vinculado aos direitos fundamentais do trabalhador e à proteção da relação de emprego.

Elucidativas são as lições de Maurício Godinho Delgado no sentido de que o "FGTS é instituto de natureza multidimensional, complexa, com preponderante estrutura e fins justrabalhistas, os quais se combinam, porém, harmonicamente, a seu caráter de fundo social de destinação variada, tipificada em lei"27.

Quanto à consideração do FGTS em sua finalidade justrabalhista, impende vinculá-la à proteção da relação de emprego, especialmente por se caracterizar num regime jurídico concebido para substituir o modelo da estabilidade decenal.

\footnotetext{
${ }^{25}$ Disponível em http://www.fgts.gov.br/noticias. Acesso em: 15.10.2010.

${ }^{26}$ JANTAIA, Fabiano. FGTS - Fundo de Garantia do Tempo de Serviço. São Paulo: LTr, 2008, p. 48.

${ }^{27}$ DELGADO, Maurício Godinho. Curso de direito do trabalho. São Paulo: LTr, 2006, p. 1273.
} 
Com efeito, a partir da vigência da Constituição Federal de 1988, o FGTS foi alçado à categoria de direito fundamental do trabalhador, consoante expressa disposição do seu artigo $7^{\circ}$, III, constituindo-se em um regime obrigatório, e não mais opcional, de superposição ao da garantia contra a dispensa arbitrária ou sem justa causa prevista no inciso I do mesmo artigo.

De se destacar que o inciso I, do artigo 10, do Ato das Disposições Constitucionais Transitórias - ADCT, estatuiu que até que seja promulgada a lei complementar a que se refere o artigo $7^{\circ}$, I, da Constituição Federal, sobre a garantia do trabalhador contra a dispensa arbitrária ou sem justa causa, fica limitada a proteção nele referida ao aumento, para quatro vezes, da porcentagem prevista no artigo $6^{\circ}$, caput e $\S 1^{\circ}$, da Lei $\mathrm{n}^{\mathrm{o}}$ 5.107, de 13 de setembro de 1966, observando-se que esta lei ordinária foi revogada pela vigente Lei 8.036/90, que trata do Fundo de Garantia do Tempo de Serviço FGTS.

Assim, o FGTS atualmente encontra-se umbilicalmente atrelado à proteção da relação de emprego no Brasil em face da dispensa arbitrária ou sem justa causa.

As reflexões sobre as finalidades e a natureza multidimensional do Fundo de Garantia do Tempo de Serviço, especialmente no que tange ao seu caráter substitutivo do regime de estabilidade decenal no emprego, perpassa pelo reconhecimento de um processo de redefinição da formação social brasileira no cenário capitalista internacional.

Assim, a modificação da legislação trabalhista com a supressão da estabilidade decenal e criação do FGTS, inicialmente como sistema alternativo, representou uma resposta às exigências de internacionalização da economia brasileira, consolidada a partir da Constituição Federal de 1988, com a obrigatoriedade do FGTS.

Nesse panorama torna-se possível a evidenciação da faceta do Fundo de Garantia do Tempo de Serviço como fator estimulante do fluxo das inversões estrangeiras e do enorme potencial para servir como fonte de investimentos destinados a subsidiar políticas econômico-sociais do sistema financeiro da habitação, saneamento básico, infraestrutura urbana e infraestrutura de base relacionada ao direcionamento de recursos a segmentos como os de portos, ferrovias e geração de energia. 
Diante das suas finalidades trabalhista e econômico-social, o descumprimento da obrigação de recolher os depósitos para o Fundo de Garantia do Tempo de Serviço é uma transgressão grave não somente ao direito individual de crédito do trabalhador, mas também à toda a sociedade, na qualidade de beneficiária dos investimentos públicos decorrentes das aplicações vinculadas, os quais certamente contribuem para a alavancar o desenvolvimento nacional e o nível de emprego ${ }^{28}$.

\subsection{O FGTS e o direito comparado}

Cumpre registrar que não existe na legislação comparada um modelo instituído nos parâmetros do FGTS brasileiro, ligado à promoção de desenvolvimento social e à proteção da relação de emprego, especialmente quanto ao pagamento de recursos ao trabalhador como forma de indenização ou compensação pelo tempo de serviço.

Há modelos de fundos trabalhistas na América Latina que denotam uma preocupação legislativa de amparo ao trabalhador em hipóteses de cessação do contrato de trabalho e dispensas imotivadas, mas não têm a amplitude econômico-social que o FGTS assume no Brasil.

Nos termos do artigo 164 do Código do Trabalho chileno ${ }^{29}$, com redação consolidada pelo Decreto com força de lei $\mathrm{n}^{\mathrm{o}} 1$, de 16 de janeiro de 2003, as partes do contrato de trabalho, a contar do início do sétimo ano da relação laboral, podem substituir a indenização devida pela dispensa de empregado com mais de ano de contrato, prevista no artigo 163, do mesmo código, por um sistema de indenização devida pela simples terminação da relação de trabalho, qualquer que seja a causa da qual origine, exclusivamente no que se refere ao lapso posterior aos primeiros seis anos de serviços

\footnotetext{
${ }^{28}$ SÜSSEKIND, Arnaldo; MARANHÃO, Délio; VIANNA, Segadas; TEIXEIRA, Lima. Instituições de direito do trabalho. Op. cit, p. 665.

${ }^{29}$ Disponível em http://www.dt.gob.cl. Acesso em: 25.11.2010.
} 
prestados até o final do décimo primeiro ano da relação de trabalho.

Este acordo de indenização substitutiva deve ser realizado por escrito, e será custeado por depósitos mensais efetuados pelo empregador, em aporte não inferior ao equivalente a 4,11\% das remunerações mensais do trabalhador, a partir da data do acordo. $\mathrm{O}$ empregador deve depositar mensalmente os percentuais referidos junto à administradora de fundo de pensão a que se encontra afiliado o trabalhador. Os recursos referentes ao acordo de indenização substitutiva depositados no fundo de pensão do trabalhador somente podem ser levantados demonstrada a rescisão do contrato de trabalho por qualquer motivo, e em situações específicas previstas na legislação, sendo que os fundos de pensão podem cobrar comissões pela administração, incidentes sobre os depósitos efetuados pelo empregador nesse sistema.

$\mathrm{Na}$ Colômbia, relativamente às indenizações por cessação do vínculo de emprego, identificam-se em substituição às indenizações rescisórias os fondos de cestanía, regulados pela Lei $\mathrm{n}^{\circ} 50$, de 28 de dezembro de $1990^{30}$.

A legislação colombiana estabelece uma sistemática de depósitos anuais de responsabilidade do empregador em contas individuais de capitalização, abertas em instituições criadas para administrar os fondos de cestanía, passíveis de levantamento pelo obreiro nas hipótese de cessação do contrato de trabalho, por qualquer razão, inclusive em caso de quebra da empresa.

$\mathrm{Na}$ Europa sobressaem-se modelos de fundos de garantia salarial, à semelhança de seguros, para salvaguardar o trabalhador diante de situações de insolvência do empregador, seguindo disposições das Diretivas Européias 80/987/CEE, 2002/74/CE e 2008/94/CE, que encontram suporte também na Convenção $n^{\circ} 173$ da Organização Internacional do Trabalho.

A Diretiva 80/987/CEE, de 20 de outubro de 1980, acompanhada pela Diretiva Européia 2002/74/CE, do Parlamento Europeu e do Conselho, determina aproximação das legislações dos Estados membros relativas à proteção dos trabalhadores assalariados em hipótese de insolvência da empresa. No mesmo sentido, estabelece a Diretiva Européia 2008/94/CE, de 22 de outubro de 2008, regras sobre a proteção dos

\footnotetext{
${ }^{30}$ Disponível em http://www.secretariasenado.gov.co. Acesso em: 25.11.2010.
} 
trabalhadores assalariados no caso de insolvência do empresário.

Por sua vez, a Convenção da Organização Internacional do Trabalho $n^{\circ}$ 173, de 23 de junho de 1992, estatui a necessidade de proteção dos créditos trabalhistas no caso de insolvência do empregador. A proteção referenciada pode ocorrer por meio de um privilégio dos créditos trabalhistas para pagamento com ativos do empregador insolvente antes de créditos não privilegiados de outros credores $^{31}$, e também por meio de instituição de uma garantia. De se registrar que essa convenção não foi ratificada pelo Brasil.

Adotando o modelo estabelecido nas diretivas européias e na convenção da OIT citadas, a Espanha, mediante disposições incluídas no Estatuto de los trabajadores $^{32}$, Lei $^{\text {o }}$ 8, de 10 de março de 1980, em seu artigo 33, instituiu El Fondo de Garantia Salarial (FOGASA), como órgão autônomo, com personalidade jurídica própria, vinculado ao Ministério do Trabalho e Assuntos Sociais, com o objetivo de realizar, subsidiariamente, o pagamento de verbas salariais e outras obrigações que não forem adimplidas pelo empregador em situação jurídica de insolvência, suspensão de pagamentos ou falência.

O órgão assume as obrigações de pagamento das indenizações reconhecidas em sentença, ato de conciliação judicial ou decisão administrativa em favor dos trabalhadores, bem como de indenizações por extinção de contratos de trabalho temporários ou estabelecidos por prazo determinado ${ }^{33}$.

A legislação espanhola estipula um valor máximo que o Fundo de Garantia Salarial se responsabiliza, correspondente aos anos de trabalho do empregado. Posteriormente à satisfação do débito o Fundo sub-roga-se nos direitos do trabalhador e pode buscar o ressarcimento junto ao empregador inadimplente.

\footnotetext{
${ }^{31}$ A concessão de privilégio ao crédito trabalhista no Brasil constou do artigo 449 da CLT, diante de falência ou liquidação judicial da empresa, bem como do Decreto-Lei 7661/45. Após a ratificação da Convenção 95/OIT, em 14.10.1977, que previa garantia de privilégio ao crédito trabalhista, constou expressamente no parágrafo primeiro do artigo 449 da CLT que, na falência, constituíam créditos privilegiados a totalidade dos salários devidos ao empregado e a totalidade das indenizações a que tiver direito. A Convenção 95 da OIT foi superada pela Convenção 173, não ratificada pelo Brasil, sendo que a Lei $\mathrm{n}^{\mathrm{o}} 11.101 / 05$, introduzida no ordenamento jurídico pátrio para regular a recuperação judicial, extrajudicial e a falência, limitou, em seu artigo 83, I, o privilégio do crédito trabalhista em 150 salários-mínimos na classificação dos créditos na falência.

${ }^{32}$ Disponível em http://www.mtin.es/fogasa. Acesso em: 29.05.2011.

${ }^{33}$ TORRES, Manuela Ramos. El fondo de garantia salarial: configuración y analisis de su regimén juridico sustantivo. Granada: Comares, 2000, p. 21/36.
} 
O custeio do FOGASA se dá mediante recolhimento de recursos pelos empregadores públicos e privados, tendo como base de cálculo o valor dos salários dos trabalhadores admitidos.

Sobre o FOGASA espanhol, a doutrina leciona que se trata de um organismo autônomo, dependente do Ministério do Trabalho e Seguridade Social, tendo personalidade jurídica e capacidade para o cumprimento de seus mister para abonar o trabalhador dos salários pendentes de pagamento em virtude de insolvência, suspensão de pagamento, quebra ou concurso de credores dos empresários. O Fundo, ou FOGASA é regido pelo artigo 33 do Estatuto dos Trabalhadores, de 14 de março de 1980, com a redação dada pelo Real Decreto Legislativo $n^{\circ} 1$ de 24/3/1995 $5^{34}$.

Em Portugal existe o Fundo de Garantia Salarial, o qual, por força do artigo $12^{\circ}, n^{\circ} 6$, al. "o", da Lei no 7/2009, de 12 de fevereiro, que instituiu o novo Código do Trabalho, e enquanto não for publicada sua legislação especial, está disciplinado pelos artigos $317^{\circ}$ a $326^{\circ}$ do anterior Regulamento do Trabalho ${ }^{35}$, aprovado pela Lei 35/2004, de 29 de julho, o qual estabelece que sua finalidade é assegurar ao trabalhador o pagamento dos créditos emergentes do contrato de trabalho e da sua violação ou cessação, nos casos em que o empregador inadimplente seja declarado insolvente por decisão judicial.

Instituto semelhante ao espanhol e ao português está previsto na legislação do Reino Unido, que por meio do Employment Rights Act ${ }^{36}$, de 1996, na seção 182, estabelece que em situação de insolvência comprovada do empregador o trabalhador pode solicitar ao Secretário de Estado que o pagamento das verbas salariais que lhe são devidas seja realizado pelo Fundo Nacional de Seguros, o qual também se sub-roga como credor do empregador inadimplente.

Nos sistemas espanhol, português e britânico, em realidade, identificamse regimes de proteção e garantia salarial, à semelhança de seguros, capitaneados pelos fundos em face do inadimplemento de verbas salariais devidas pelos empregadores, restritos, entretanto, ao albergamento das situações de cessação do contrato de trabalho nas hipótese de insolvência.

\footnotetext{
${ }^{34}$ MARTINS, Sérgio Pinto. In Perspectivas da Justiça do Trabalho. Suplemento. São Paulo: LTr 176/99, p. 923.

${ }^{35}$ Disponível em http://www2.seg-social.pt. Acesso em: 28.11.2010.

${ }^{36}$ Disponível em http://www.legislation.gov.uk. Acesso em: 02.12.2010.
} 
Diferentemente, o modelo de fundo adotado na Áustria tem por finalidade a garantia de indenização em face da perda do emprego por dispensa ou aposentadoria.

O modelo austríaco baseia-se na formação de um fundo pessoal ao empregado, com característica de portabilidade diante da cessação do contrato de trabalho e nova contratação. O empregado que não sacar os valores diante da situação de perda do emprego, pode destinar os recursos angariados ao seu fundo para a nova relação de trabalho ou destiná-lo ao fundo de pensão. Os fundos são administrados por gestores devidamente autorizados pelo Estado, e cada empresa está associada a um gerente independente. $\mathrm{O}$ modelo austríaco reduz o custo empresarial com as indenizações por dispensa dos trabalhadores, e por isso tem sido objeto de pauta em diversos Estados europeus diante de crises econômicas.

Os modelos de fundo de garantia salarial diante de insolvência do empregador previstos nas diretivas européias e nas normas da OIT poderiam ter servido de fonte para evolução do instituto do Fundo de Garantia do Tempo de Serviço brasileiro.

Conforme fixado linhas acima, a finalidade trabalhista do FGTS revelase pelo crédito compensatório do tempo de serviço do trabalhador para albergá-lo diante de contingências legalmente previstas e servir como regime de indenização por sua dispensa arbitrária ou sem justa causa. Assim, o Fundo de Garantia do Tempo de Serviço não tem a finalidade de garantia salarial.

Sobre as contingências legalmente previstas, o artigo 20, inciso II, da Lei 8.036/90, estabelece como hipótese de saque de recursos do FGTS, a extinção total da empresa, o fechamento de quaisquer de seus estabelecimentos, filiais ou agências, a supressão de parte de suas atividades, a declaração de nulidade do contrato de trabalho por ausência de concurso público, ou ainda o falecimento do empregador individual sempre que qualquer dessas ocorrências implique rescisão de contrato de trabalho, comprovada por declaração escrita da empresa, suprida, quando for o caso, por decisão judicial transitada em julgado. Todavia, essas hipóteses de levantamento de valores não representam a garantia dos salários devidos e não pagos pelos empregadores insolventes, pois o trabalhador receberá uma compensação pelo tempo de serviço, mas não eventuais salários não quitados. 
A Emenda Constitucional $\mathrm{n}^{\mathrm{o}} 45 / 04$, como alento, revelou uma preocupação em se garantir o pagamento das verbas trabalhistas, pois estabeleceu em seu artigo $3^{\circ}$ que “a lei criará o Fundo de Garantia das Execuções Trabalhistas, integrado pelas multas decorrentes de condenações trabalhistas e administrativas oriundas da fiscalização do trabalho, além de outras receitas". Esse Fundo de Garantia das Execuções Trabalhistas (FGET), cuja lei instituidora pende de discussão no parlamento brasileiro, tornará mais efetiva a execução das sentenças trabalhistas, e poderá suprir a lacuna deixada pela legislação do FGTS há décadas quanto à garantia salarial.

De todo modo, em toda a legislação estrangeira acima analisada identifica-se, na criação dos fundos estatais considerados, uma preocupação em proteção da relação de trabalho diante da cessação do contrato de trabalho. E, de maneira específica, os fundos austríaco, colombiano e chileno, apresentam uma relação mais próxima com o FGTS brasileiro no que tange à proteção do trabalhador, mediante indenização, em face de dispensas sem justa causa pelo empregador.

\subsection{Recursos e administração do Fundo}

A questão conceitual sobre os recursos que compõem o Fundo de Garantia do Tempo de Serviço é preliminar ao desenvolvimento do presente trabalho, pois consubstancia o elemento delimitador do campo jurídico pesquisado.

O instituto do FGTS sob a ótica da sua massa de recursos encerra um complexo de relações jurídico-obrigacionais que pode ser sintetizado sob uma ótica tridimensional.

De um lado existe o vínculo entre as partes da relação de trabalho, conforme se extrai do artigo 15, da Lei 8.036/90, o qual cria para o empregador, dentre outros, o dever principal de efetuar recolhimento mensal e rescisório da contribuição ao 
FGTS em conta vinculada aberta em nome do empregado. Dessa forma, há por parte do empregado o direito subjetivo de instar o empregador ao cumprimento da obrigação de efetuar os depósitos mensais e rescisório.

De outro lado, há o vínculo entre o empregador e o Estado, compreendidos os órgãos da Administração Pública Direta e Indireta da União, legalmente vinculados à administração e gerência do fundo, donde decorre o poder estatal de fiscalizar o cumprimento das obrigações legalmente impostas, de aplicar as penalidades e sanções correspondentes na hipótese de inobservância, e também de arrecadar os depósitos mensais e rescisórios, e promover a cobrança administrativa e judicial dos créditos.

Por fim, existe o vínculo entre a União e o empregado no que tange ao controle e remuneração das contas vinculadas, além da liberação dos recursos ao trabalhador nas hipóteses legais, como atividades confiadas à Caixa Econômica Federal, empresa pública com atribuição de agente operador dos recursos do FGTS.

Cumpre registrar que os recursos do fundo não se limitam aos depósitos vinculados e multas decorrentes de penalidades administrativas, pois a Lei 8.036/90 dispõe que o FGTS é constituído pelo saldo das contas vinculadas e outros recursos a ele incorporados. Nessa linha, o $\S 1^{\circ}$ do artigo $2^{\circ}$, da citada lei, estabelece que constituem recursos incorporados ao FGTS, as dotações orçamentárias específicas, os resultados das aplicações dos recursos do FGTS, as multas, a correção monetária e os juros moratórios devidos, os eventuais saldos de resultados financeiros auferidos pela Caixa Econômica Federal no período entre o repasse dos bancos que anteriormente recebiam os recolhimentos e o depósito nas contas vinculadas dos trabalhadores, bem como demais receitas patrimoniais e financeiras.

Entretanto, para os fins da presente investigação científica faz-se um recorte a partir da pressuposta hipótese de inadimplência do recolhimento de valores devidos ao FGTS pelo empregador, sendo que, de toda a gama de recursos, destacam-se apenas os depósitos vinculados mensais e rescisórios, bem como as multas aplicadas pela fiscalização do trabalho, cingindo-se assim, às relações creditórias decorrentes dos dois primeiros vínculos acima apontados: entre o trabalhador e o empregador, e entre a União e o empregador. 
Em suma, para o objeto da presente análise, são levados em consideração apenas os recursos ou créditos do FGTS decorrentes das contribuições devidas pelo empregador relativas aos depósitos vinculados mensais e rescisórios, bem como das multas aplicadas pela fiscalização do trabalho em decorrência do descumprimento das regras do Fundo.

De forma geral, no que respeita à gestão administrativa dos recursos do FGTS, a legislação de regência a atribuiu a diversos órgãos da Administração Pública Federal, fracionando-a em três partes: administração, atribuída ao Conselho Curador como órgão colegiado vinculado ao Ministério do Trabalho e Emprego; gestão das aplicações, atribuída ao Ministério da Ação Social, hoje Ministério das Cidades; e operação, atribuída à Caixa Econômica Federal.

A instância máxima de gestão e administração do Fundo de Garantia é o Conselho Curador, um colegiado tripartite, composto por representantes dos trabalhadores indicados pelas Centrais Sindicais, dos empregadores, indicados pelas Confederações Nacionais da Indústria, do Comércio, dos Transportes e das Instituições Financeiras, e do Governo Federal, atendendo ao disposto no artigo 10 da Constituição Federa de 1988, que determina composição paritária quando os interesses de trabalhadores e empregadores se fizerem presentes em colegiados dos órgãos Públicos.

Segundo o artigo $5^{\circ}$, da Lei 8.036/90, incumbe ao Conselho Curador, dentre outras atribuições: estabelecer as diretrizes e os programas de alocação de todos os recursos do FGTS, de acordo com os critérios definidos na mencionada lei, em consonância com a política nacional de desenvolvimento urbano e as políticas setoriais de habitação popular, saneamento básico e infra-estrutura urbana estabelecidas pelo Governo Federal; acompanhar e avaliar a gestão econômica e financeira dos recursos, bem como os ganhos sociais e o desempenho dos programas aprovados; apreciar e aprovar os programas anuais e plurianuais do FGTS; pronunciar-se sobre as contas do FGTS, antes do seu encaminhamento aos órgãos de controle interno para os fins legais; adotar as providências cabíveis para a correção de atos e fatos do Ministério das Cidades e da Caixa Econômica Federal, que prejudiquem o desempenho e o cumprimento das finalidades no que concerne aos recursos do FGTS; dirimir dúvidas quanto à aplicação das normas regulamentares, relativas ao FGTS, nas matérias de sua competência; fixar critérios para parcelamento de recolhimentos em atraso; aprovar a política de investimento do FI-FGTS por proposta do 
Comitê de Investimento; decidir sobre o reinvestimento ou distribuição dos resultados positivos aos cotistas do FI-FGTS, em cada exercício; definir a forma de deliberação, de funcionamento e a composição do Comitê de Investimento do FI-FGTS; definir a exposição máxima de risco dos investimentos do FI-FGTS; estabelecer o limite máximo de participação dos recursos do FI-FGTS por setor, por empreendimento e por classe de ativo, observados os requisitos técnicos aplicáveis; estabelecer o prazo mínimo de resgate das cotas e de retorno dos recursos à conta vinculada; autorizar a integralização de cotas do FIFGTS pelos trabalhadores, estabelecendo previamente os limites globais e individuais, parâmetros e condições de aplicação e resgate.

Em resumo, pode-se dizer que compete ao Conselho Curador estabelecer as diretrizes e os programas de alocação dos recursos do FGTS, bem como avaliar seu desempenho, aprovar a política de investimento do FI-FGTS proposta pelo Comitê de Investimento e examinar as contas do Fundo.

O Conselho Curador do FGTS, consoante Decreto 6.827/2009, é formado por doze representantes do Governo Federal, seis representantes dos trabalhadores e seis representantes dos empregadores. O Conselho conta ainda, com a assessoria do Grupo de Apoio Permanente (GAP), estrutura formada por consultores técnicos das 24 entidades com assento no órgão, sendo que seus integrantes se reúnem semanalmente para analisar temas que estão em deliberação pelo Conselho Curador.

A Presidência do Conselho Curador é ocupada pelo Ministro do Trabalho e Emprego, cabendo ao Ministro das Cidades a Vice-Presidência. A Secretaria Executiva é ocupada pelo coordenador-geral do FGTS. Com um integrante cada, também têm assento no Conselho a Casa Civil da Presidência da República, a Secretaria Geral da Presidência da República e os Ministérios da Fazenda, do Desenvolvimento, Indústria e Comércio Exterior, do Planejamento, Orçamento e Gestão, da Saúde, dos Transportes, além da Caixa Econômica Federal e do Banco Central do Brasil.

No que tange à participação dos trabalhadores, seis representantes participam do Conselho, indicados atualmente pelas entidades: Força Sindical, Central Única dos Trabalhadores (CUT), União Geral dos Trabalhadores (UGT), Central dos Trabalhadores e Trabalhadoras do Brasil (CTB), Central Geral dos Trabalhadores do Brasil (CGTB) e Nova Central Sindical de Trabalhadores (NCST). 
Por fim, também são seis os conselheiros representantes dos empregadores, indicados pelas entidades: Confederação Nacional da Indústria (CNI), Confederação Nacional do Sistema Financeiro (CONSIF), Confederação Nacional do Comércio de Bens, Serviços e Turismo (CNC), Confederação Nacional de Serviços (CNS), Confederação Nacional de Saúde, Hospitais, Estabelecimentos e Serviços (CNS) e Confederação Nacional do Transporte (CNT).

A gestão de aplicação dos recursos do FGTS é de competência do atual Ministério das Cidades, referido no artigo $6^{\circ}$ da Lei 8.036/90 como Ministério da Ação Social, ao qual incumbe: praticar todos os atos necessários à gestão da aplicação do Fundo, de acordo com as diretrizes e programas estabelecidos pelo Conselho Curador; expedir atos normativos relativos à alocação dos recursos para implementação dos programas aprovados pelo Conselho Curador; elaborar orçamentos anuais e planos plurianuais de aplicação dos recursos, discriminando-os por Unidade da Federação, submetendo-os até 31 de julho ao Conselho Curador do Fundo; acompanhar a execução dos programas de habitação popular, saneamento básico e infraestrutura urbana, decorrentes de aplicação de recursos do FGTS, implementados pela CEF; submeter à apreciação do Conselho Curador as contas do FGTS; subsidiar o Conselho Curador com estudos técnicos necessários ao aprimoramento operacional dos programas de habitação popular, saneamento básico e infraestrutura urbana; e definir as metas a serem alcançadas nos programas de habitação popular, saneamento básico e infraestrutura urbana.

Por sua vez, à Caixa Econômica Federal é atribuído pela Lei 8.036/90 o papel de agente operador dos recursos do FGTS, incumbindo-lhe neste mister: centralizar os recursos do FGTS, manter e controlar as contas vinculadas, e emitir regularmente os extratos individuais correspondentes às contas vinculadas e participar da rede arrecadadora dos recursos do FGTS; expedir atos normativos referentes aos procedimentos administrativo-operacionais dos bancos depositários, dos agentes financeiros, dos empregadores e dos trabalhadores, integrantes do sistema do FGTS; definir os procedimentos operacionais necessários à execução dos programas de habitação popular, saneamento básico e infraestrutura urbana, estabelecidos pelo Conselho Curador com base nas normas e diretrizes de aplicação elaboradas pelo Ministério das Cidades; elaborar as análises jurídica e econômico-financeira dos projetos de habitação popular, infraestrutura urbana e saneamento básico a serem financiados com recursos do FGTS; emitir Certificado 
de Regularidade do FGTS; elaborar as contas do FGTS, encaminhando-as ao Ministério das Cidades; implementar os atos emanados do Ministério das Cidades relativos à alocação e aplicação dos recursos do FGTS, de acordo com as diretrizes estabelecidas pelo Conselho Curador; e, garantir aos recursos alocados ao FI-FGTS, em cotas de titularidade do FGTS, a remuneração aplicável às contas vinculadas.

Do quanto exposto extrai-se que a administração dos recursos do FGTS, como fundo público de natureza social, é atribuída pela legislação à União, envolvendo órgãos da administração direta, como o Ministério do Trabalho e Emprego, ao qual está vinculado o Conselho Curador do Fundo, e o Ministério das Cidades, além da Caixa Econômica Federal, empresa pública que figura como entidade da administração indireta federal vinculada ao Ministério da Fazenda.

No que tange à fiscalização, apuração e cobrança judicial das contribuições e multas devidas ao Fundo de Garantia do Tempo de Serviço figuram ainda como protagonistas dois órgãos da União.

Com efeito, ao Ministério do Trabalho e Emprego é atribuído pelo artigo 23, da Lei 8.036/80, a tarefa de verificar em nome da Caixa Econômica Federal o cumprimento das regras do FGTS, especialmente quanto à apuração dos débitos e das infrações praticadas pelos empregadores ou tomadores de serviço, competindo-lhe notificálos para que efetuem e comprovem os depósitos correspondentes e cumpram as demais determinações legais, podendo, para tanto, contar com o concurso de outros órgãos do Governo Federal.

No mesmo sentido, estabelece o artigo $1^{\circ}$, da Lei 8.844/94, incumbir ao Ministério do Trabalho e Emprego a fiscalização e a apuração das contribuições ao Fundo de Garantia do Tempo de Serviço, bem como a aplicação das multas e demais encargos devidos, devendo a Caixa Econômica Federal prestar as informações necessárias ao cumprimento desse desiderato.

Por sua vez, determina o artigo $2^{\circ}$, da Lei 8.844/94, que é de competência da Procuradoria-Geral da Fazenda Nacional a representação judicial e extrajudicial do FGTS para a correspondente cobrança das contribuições, das multas e demais encargos previstos na legislação respectiva, bem como a atividade de inscrição em dívida ativa dos 
créditos do Fundo.

Registre-se que, nos termos da lei citada, a mencionada representação judicial e extrajudicial do FGTS atribuída à Procuradoria-Geral da Fazenda Nacional pode ser exercida por intermédio da Caixa Econômica Federal, mediante convênio. Este instrumento foi firmado em 1996, e ainda se encontra vigente, atribuindo à CEF a representação judicial e extrajudicial do FGTS, exceto no que pertine aos créditos acrescidos das contribuições sociais tributárias previstas na LC 110/01, referentes ao incremento de $0,5 \%$ na alíquota das contribuições mensais dos empregadores, e de $10 \%$ na alíquota referente à indenização rescisória de 40\%, conforme artigo 10, I do ADCT.

Cumpre consignar que o Ministério Público do Trabalho também está legitimado para garantir o cumprimento da legislação do FGTS, especialmente na tarefa de promover inquérito civil e ação civil pública para defesa de interesses coletivos, e sobretudo de interesses difusos da sociedade, decorrentes da aplicação dos seus recursos ${ }^{37}$.

\subsection{Modelo de recuperação dos créditos do FGTS}

O Fundo de Garantia do Tempo de Serviço encerra um complexo de relações jurídicas sintetizado numa ótica tridimensional, conforme exposto linhas acima, consistente na relação entre os sujeitos da relação de trabalho, na relação entre o Estado e o empregador, e na relação entre o Estado e o empregado.

No âmbito da restrição temática toma-se o FGTS quanto às relações jurídicas obrigacionais pecuniárias determinadas pelos vínculos entre os sujeitos da relação de trabalho, e o vínculo estabelecido entre o Estado e o empregador.

\footnotetext{
${ }^{37}$ SÜSSEKIND, Arnaldo; MARANHÃO, Délio; VIANNA, Segadas; TEIXEIRA, Lima. Instituições de direito do trabalho. Op. cit., p. 681.
} 
Na hipótese da relação jurídica estabelecida entre os sujeitos da relação de trabalho, o recolhimento dos depósitos mensais ao FGTS pelo empregador é determinado pelo artigo 15, da Lei 8.036/90, o qual determina que todos os empregadores ficam obrigados a depositar, até o dia 7 (sete) de cada mês, em conta bancária vinculada na Caixa Econômica Federal, a importância correspondente a 8 (oito) por cento da remuneração paga ou devida, no mês anterior, a cada trabalhador, incluídas na remuneração as parcelas de que tratam os arts. 457 e 458 da CLT e a gratificação de Natal a que se refere a Lei $\mathrm{n}^{\mathrm{o}} 4.090$, de 13 de julho de 1962, com as modificações da Lei $\mathrm{n}^{\mathrm{o}}$ 4.749, de 12 de agosto de 1965.

Ocorrendo rescisão do contrato de trabalho por parte do empregador, este deverá depositar na conta vinculada do trabalhador os valores relativos aos depósitos referentes ao mês da rescisão e ao imediatamente anterior, que ainda não houver sido recolhido, sem prejuízo das cominações legais, na esteira do artigo 18, caput da Lei $8.036 / 90$.

Ainda como obrigação decorrente da relação de trabalho, no caso de dispensa arbitrária ou sem justa causa, o empregador fica obrigado a depositar na conta vinculada do trabalhador no FGTS importância igual a 40\% (quarenta por cento) do montante de todos os depósitos realizados na sua conta vinculada durante a vigência do contrato de trabalho, atualizados monetariamente e acrescidos dos respectivos juros, consoante estabelece o artigo $18, \S 1^{\circ}$ da citada lei.

Se a rescisão do contrato de trabalho decorrer de culpa recíproca ou força maior, reconhecida pela Justiça do Trabalho, o empregador fica obrigado a depositar na conta vinculada do trabalhador no FGTS importância igual a 20\% (vinte por cento) do montante de todos os depósitos realizados na conta vinculada durante a vigência do contrato de trabalho, atualizados monetariamente e acrescidos dos respectivos juros, consoante estabelece o artigo $18, \S 2^{\circ}$ da Lei geral do FGTS.

Esses depósitos estabelecidos pelo artigo $18, \S 1^{\circ}$ e $\S 2^{\circ}$, da Lei 8.036/90 são denominados depósitos rescisórios, respectivamente decorrentes da dispensa sem justa causa ou da extinção do contrato de trabalho por culpa recíproca ou força maior, os quais não se confundem com os depósitos mensais, tampouco com a sua sistemática de cálculo e pagamento na ocasião da rescisão do contrato de trabalho estabelecida do caput do artigo 
18 da Lei 8.036/90.

Ocorrendo a hipótese de inadimplência dos depósitos mensais e rescisórios do FGTS na respectiva conta vinculada em nome do trabalhador na Caixa Econômica Federal abre-se a possibilidade de sua recuperação pelo próprio empregado prejudicado, por meio do ajuizamento da competente ação trabalhista.

Essa possibilidade decorre de disposição expressamente prevista no artigo 26, caput e parágrafo único, da Lei 8.036/90, ao firmar a competência da Justiça do Trabalho para julgar os dissídios entre os trabalhadores e os empregadores decorrentes do FGTS, mesmo quando a Caixa Econômica Federal e o Ministério do Trabalho e Emprego figurarem como litisconsortes, estabelecendo que nas ações trabalhistas que objetivarem o ressarcimento de parcelas relativas ao FGTS, ou que, direta ou indiretamente, implicarem essa obrigação de fazer, o juiz determinará que o empregador sucumbente proceda ao recolhimento imediato das importâncias devidas sob tal epígrafe.

Nesta hipótese, por se tratar de dissídio fundado na relação de trabalho, com fundamento no artigo 114, I, da Constituição Federal, o veículo para a recuperação dos créditos é a ação trabalhista a ser proposta na Vara do Trabalho competente, seguindo os trâmites estabelecidos nos artigos 837 e seguintes, da Consolidação das Leis do Trabalho - CLT, por meio da qual se deduz o descumprimento das obrigações legais impostas pela Lei 8.036/90, com requerimento de condenação do empregador ao recolhimento dos valores correspondentes.

Ao final do processo judicial, havendo condenação do empregador ao recolhimento dos recursos do FGTS, este deverá fazê-lo em conta vinculada do trabalhador autor da ação trabalhista, o qual poderá inclusive promover-lhe a execução se não instaurada de ofício.

Por sua vez, no que concerne à dimensão da relação jurídica obrigacional que se estabelece entre o Estado e o empregador, referente aos recolhimentos dos valores de depósitos mensais e rescisórios, bem como de multas aplicadas pela fiscalização do trabalho exercida pelo Ministério do Trabalho e Emprego, o seu fundamento jurídico encontra-se estabelecido no artigo 23 da Lei 8.036/90, o qual estabelece que compete ao Ministério do Trabalho e Emprego a verificação, em nome da Caixa Econômica Federal, 
do cumprimento do disposto na citada lei, especialmente quanto à apuração dos débitos e das infrações praticadas pelos empregadores ou tomadores de serviço, notificando-os para efetuarem e comprovarem os depósitos correspondentes e cumprirem as demais determinações legais, podendo, para tanto, contar com o concurso de outros órgãos do públicos federais, na forma que vier a ser regulamentada.

O $\S 1^{\circ}$ do artigo considerado, tipifica as infrações, dentre elas: não depositar mensalmente o percentual referente ao FGTS, bem como os valores previstos no artigo 18 da Lei 8.036/90, nos prazos de que trata o $\S 6^{\circ}$ do artigo 477 da Consolidação das Leis do Trabalho; deixar de computar, para efeito de cálculo dos depósitos do FGTS, parcela componente da remuneração; e deixar de efetuar os depósitos e os acréscimos legais, após notificado pela fiscalização.

Por sua vez, em complemento, o $\S 2^{\circ}$ do mesmo artigo estabelece as penas de multa pelas infrações tipificadas no $\S 1^{\circ}$ deste artigo. Nos casos de fraude, simulação, artifício, ardil, resistência, embaraço ou desacato à fiscalização, assim como na reincidência, a multa será duplicada, sem prejuízo das demais cominações legais, consoante determinação do $\S 3^{\circ}$ do artigo 23 .

O processo de fiscalização, de autuação e de imposição de multas do FGTS rege-se pelo disposto no Título VII da Consolidação das Leis do Trabalho, conforme estabelece o $\S 5^{\circ}$ do artigo 23 , da Lei 8.036/90.

Observadas as disposições do artigo reproduzido extrai-se que diante da inadimplência do empregador quanto ao cumprimento das obrigações de recolhimento na conta vinculada do trabalhador dos depósitos mensais e rescisórios ao Fundo de Garantia do Tempo de Serviço, na forma determinada pelos artigos 15 e 18 , caput, $\S 1^{\circ}$ e $\S 2^{\circ}$, da Lei 8.036/90, será possível a cobrança pela União dos valores devidos ao FGTS pelo empregador.

A relação jurídica obrigacional entre o Estado e o empregador referente aos créditos do FGTS, também tem como fundamento a aplicação das multas pelo Ministério do Trabalho e Emprego, em decorrência dos fatos previstos no $\S 1^{\circ}$, I a V, do artigo 23 da Lei 8.036/90, consistentes em: não realizar o depósito mensal, no prazo legalmente estabelecido, do percentual referente ao FGTS, bem como dos valores previstos 
para as hipóteses de extinção ou rescisão do contrato de trabalho; omitir as informações sobre a conta vinculada do trabalhador; apresentar as informações ao Cadastro Nacional do Trabalhador, dos trabalhadores beneficiários, com erros ou omissões; deixar de computar, para efeito de cálculo dos depósitos do FGTS, parcela componente da remuneração; e deixar de efetuar os depósitos e os acréscimos legais, após notificado pela fiscalização.

Assim, tendo em vista as finalidades e as especificidades do Fundo, a cobrança de seus créditos não é relegada apenas às partes da relação de trabalho. Os órgãos de administração, gestão e fiscalização do FGTS estão inseridos na estrutura da Administração Direta da União, cabendo à Procuradoria-Geral da Fazenda Nacional a sua representação judicial e extrajudicial, nos termos do artigo $2{ }^{\circ}$ da Lei. 8.844/94, com a redação determinada pela Lei 9.467/97, c.c artigo 12 da LC 73/93.

Diante dessa conjuntura estrutural tem-se que na relação entre Estado e empregador, diante do cenário de recuperação dos créditos do Fundo de Garantia do Tempo de Serviço, estão envolvidos os seguintes órgãos e entidades federais: Ministério do Trabalho e Emprego, Procuradoria-Geral da Fazenda Nacional e Caixa Econômica Federal.

O processo de cobrança administrativo dos créditos do FGTS pelo Poder Público encontra-se regulado atualmente pela Portaria MTE 148, de 25 de janeiro de 1996.

A partir do não recolhimento dos depósitos mensais e rescisórios devidos ao FGTS pelo empregador, verificado em fiscalização procedida pelo Ministério do Trabalho e Emprego, há a expedição de notificação ao devedor, pelo auditor fiscal do trabalho, para recolhimento do valor em aberto apurado como devido.

Na hipótese de ser apurado débito, por ausência ou insuficiência dos recolhimentos mensais ao FGTS, o auditor fiscal do trabalho emitirá notificação para recolhimento dos valores devidos, a fim de que o empregador pague a importância devida. A individualização do débito é responsabilidade do empregador. Da mesma forma, sendo apurado débito por falta de recolhimento ou recolhimento a menor com relação à remuneração paga no mês da rescisão, no mês anterior, no $13^{\circ}$ salário integral ou proporcional e aviso prévio indenizados, ou quanto à indenização rescisória, conforme Lei 
$n^{\circ}$ 9.491/97, o auditor fiscal do trabalho emitirá a notificação para recolhimento dos valores correspondentes, a fim de que o empregador efetue o pagamento da importância devida.

Não ocorrendo o recolhimento notificado dos valores devidos ao FGTS, será lavrado auto de infração e aplicada a penalidade correspondente, podendo o empregador discutir administrativamente o Auto de Infração e as subjacentes notificações fiscais perante o órgão local do Ministério do Trabalho e Emprego.

Da decisão administrativa de primeira instância cabe recurso à Secretaria de Fiscalização do Trabalho ou Secretaria de Segurança e Saúde no Trabalho, como órgãos de segunda instância administrativa na atual estrutura do Ministério do Trabalho e Emprego. Confirmados o auto de infração e as notificações fiscais de recolhimento o crédito do FGTS será inscrito em dívida ativa da União pela Procuradoria-Geral da Fazenda Nacional, a qual perseguirá judicialmente, por meio de processo de execução fiscal, os valores devidos ao Fundo.

Neste aspecto cumpre ressaltar que, a inscrição em dívida e a respectiva cobrança ou discussão judicial ocorrem separadamente em relação ao auto de infração e às notificações fiscais de recolhimento emitidas pela autoridade administrativa do trabalho.

Assim, a penalidade administrativa objeto do auto de infração dará ensejo à inscrição em dívida da União, a qual será cobrada judicialmente em sede de execução fiscal, promovida pela Procuradoria-Geral da Fazenda Nacional, no âmbito da Justiça do Trabalho, com fundamento no artigo 114, VII, da Constituição Federal, fruto da Emenda Constitucional n. ${ }^{\circ}$ 45/2004, que determina competir à Justiça do Trabalho processar e julgar as ações relativas às penalidades administrativas impostas aos empregadores pelos órgãos de fiscalização das relações de trabalho.

De outro lado, os créditos originários do não recolhimento das contribuições mensais ou rescisória, após a inscrição em dívida ativa da União, serão cobrados por meio de execução fiscal, a ser promovida pela Procuradoria-Geral da Fazenda Nacional ou pela Caixa Econômica Federal, esta como substituta processual nos termos do Convênio acima citado, no âmbito do Poder Judiciário Federal, com fundamento no artigo 109, I da Constituição Federal, que determina competir aos juízes federais processar e julgar as causas em que a União, entidade autárquica ou empresa pública 
federal forem interessadas na condição de autoras, rés, assistentes ou oponentes, exceto as de falência, as de acidentes de trabalho e as sujeitas à Justiça Eleitoral e à Justiça do Trabalho.

A apontada dicotomia de competências jurisdicionais no modelo de recuperação dos créditos do FGTS pelo Estado, a ser detalhada no decorrer do presente trabalho, termina por carrear impacto negativo na efetividade da recuperação dos créditos devidos pelos empregadores.

À luz das considerações expendidas, conclui-se que o modelo de recuperação dos créditos das contribuições mensais e rescisórias relativas ao FGTS, é formado pelo processo de cobrança judicial instaurado pelo próprio trabalhador no âmbito da Justiça do Trabalho, bem como pelos processos de cobrança administrativo e judicial empreendidos pela União no âmbito da Justiça Federal e da Justiça do Trabalho, incluída aqui a cobrança das multas punitivas aplicadas pela fiscalização do trabalho em face dos empregadores por infrações à legislação do Fundo de Garantia do Tempo de Serviço. 


\section{CAPÍTULO 2. A RECUPERAÇÃO JUDICIAL DAS CONTRIBUIÇÕES DO FGTS PELO TRABALHADOR}

\subsection{O interesse jurídico de matiz trabalhista}

O presente capítulo tem por escopo apresentar o modelo da recuperação dos créditos do FGTS promovida pelo próprio trabalhador, por meio do ajuizamento da competente ação trabalhista, diante da hipótese de inadimplência dos depósitos mensais e rescisórios relativos ao FGTS.

Essa possibilidade decorre de disposição expressa do artigo 26, caput e parágrafo único, da Lei 8.036/90, que determina ser competente a Justiça do Trabalho para julgar os dissídios entre os trabalhadores e os empregadores decorrentes da sua aplicação, mesmo quando a Caixa Econômica Federal e o Ministério do Trabalho figurarem como litisconsortes.

Por se tratar de dissídio fundado na relação de trabalho, com fundamento no artigo 114, I, da Constituição Federal, o veículo para a recuperação dos créditos é a ação trabalhista, a ser proposta na Vara do Trabalho competente, seguindo os trâmites estabelecidos nos artigos 837 e seguintes da Consolidação das Leis do Trabalho - CLT, deduzindo-se o descumprimento das obrigações legais impostas pela Lei 8.036/90, com requerimento de condenação do empregador ao recolhimento dos valores correspondentes.

No capítulo será realizada exposição detalhada sobre a identificação dos trabalhadores e dos empregadores obrigatoriamente inseridos no regime do Fundo de Garantia, seguida da análise do FGTS como objeto de ação trabalhista, além de apontamentos sobre a questão da prescrição dos créditos relativos ao FGTS no âmbito da Justiça do Trabalho, e da necessidade de notificação do Ministério do Trabalho e da Caixa 
Econômica Federal a respeito das ações trabalhistas.

As considerações e conclusões do presente capítulo fundamentam-se na natureza jurídica do Fundo de Garantia do Tempo de Serviço como direito fundamental do trabalhador, e toma como pano de fundo a finalidade do Fundo de Garantia do Tempo de Serviço sob o prisma do trabalhador, no que tange às sua caracterização como um fundo de reserva ou pecúlio, formado pelas contribuições mensais e obrigatórias do empregador, com o fim de compensar o tempo de serviço do trabalhador para albergá-lo diante de contingências legalmente previstas e servir como regime de indenização por sua dispensa arbitrária ou sem justa causa, no sentido da proteção do emprego.

A cobrança dos créditos relativos às contribuições do FGTS pelo trabalhador evidencia interesse patrimonial de crédito na recuperação dos correspondentes valores que não foram recolhidos, ou o foram a menor, pelo empregador durante a vigência da relação de trabalho, visando a prover de recursos a sua conta vinculada individual para fazer face aos levantamentos legalmente permitidos, bem como patenteia eficácia à garantia de emprego, uma vez que o Fundo de Garantia constitui-se no vigente regime de indenização por dispensa arbitrária ou sem justa causa, consoante artigo $7^{\circ}$, I, da $\mathrm{CF}$, combinado com artigo 10, I, do ADCT.

\subsection{Trabalhadores e empregadores no regime do FGTS}

O Fundo de Garantia do Tempo de Serviço, originalmente concebido pela Lei 5.107/66 como regime de indenização do tempo de serviço, opcional ao sistema de estabilidade decenal previsto no artigo 492 da Consolidação das Leis do Trabalho, tornou-se o regime único e obrigatório de proteção do tempo de serviço do trabalhador a partir da Constituição Federal de 1988.

Sob a ótica dos trabalhadores o Fundo de Garantia do Tempo de Serviço 
apresenta características de um fundo de reserva ou pecúlio formado pelas contribuições mensais e obrigatórias do empregador, com o fim de garantir a compensação do tempo de serviço do trabalhador. "É um sistema destinado a substituir o regime tradicional de indenização por despedida injusta (pagas a posteriori) e de estabilidade no emprego"38.

Todavia, não são todos os trabalhadores em sentido amplo que estão abarcados pelo regime do FGTS.

Nos termos do $\S 2^{\circ}$ do artigo 15 , da Lei $8.036 / 90$, para fins de aplicação do regime do Fundo de Garantia, integra o conceito de trabalhador toda pessoa física que prestar serviços a empregador, a locador ou tomador de mão-de-obra, excluídos os eventuais, os autônomos e os servidores públicos civis e militares sujeitos a regime jurídico próprio.

Ampliando o conceito de trabalhador para fins de incidência do FGTS, o artigo 16, da Lei 8.036/90, estabelece faculdade para que as empresas sujeitas ao regime da legislação trabalhista equiparem seus diretores não empregados aos demais trabalhadores sujeitos ao regime do FGTS, definindo como diretor aquele que exerça cargo de administração previsto em lei, estatuto ou contrato social, independente da denominação do cargo.

Por sua vez, o $\S 3^{\circ}$, do artigo 15 , da mesma lei, prevê a possibilidade dos trabalhadores domésticos terem acesso ao regime do FGTS, observando-se a forma estabelecida em lei. Nesse diapasão, a Lei 10.208/01, acrescentou o artigo $3^{\circ}$-A à Lei $n^{\circ}$ 5.859/72 (Lei do doméstico), estabelecendo a faculdade de inclusão do empregado doméstico no Fundo de Garantia do Tempo de Serviço, mediante requerimento do empregador, na forma do regulamento normativo correspondente.

Diante desses dispositivos legais da Lei 8.036/90 (artigo 15 , $\S 2^{\circ}$ e $3^{\circ}$, e artigo 16), a doutrina ${ }^{39}$ faz uma classificação dos trabalhadores submetidos ao regime do FGTS em dois grupos: os obrigatórios e os facultativos.

Considerando a exclusão legal dos eventuais, autônomos e dos servidores públicos civis e militares sujeitos a regime jurídico próprio, e a determinação de que são

${ }^{38}$ RUSSOMANO, Mozart Victor. Curso de Direito do Trabalho. $9^{\text {a }}$ ed. Curitiba: Juruá Editora, 2009, p. 263.

${ }^{39}$ JANTAIA, Fabiano. FGTS - Fundo de Garantia do Tempo de Serviço. Op. cit., p. 80. 
trabalhadores sujeitos ao regime do FGTS as pessoas físicas que prestarem serviços a empregador, a locador ou tomador de mão-de-obra, tem-se que a relação de subordinação é requisito essencial à submissão obrigatória ao regime do FGTS.

Portanto, são trabalhadores obrigatoriamente vinculados ao FGTS, todo o empregado celetista, público e privado, empregado rural, trabalhador avulso, trabalhador temporário, trabalhador contratado para serviços no exterior, os técnicos estrangeiros, atletas profissionais e treinadores de futebol.

De outra sorte, por determinação legal, compõem o rol de trabalhadores facultativos ao regime do FGTS os empregados domésticos e os diretores não empregados.

No que toca ao empregado celetista o regime do Fundo de Garantia do Tempo de Serviço tem aplicação independentemente da espécie de contrato ${ }^{40}$, seja por prazo indeterminado ou por prazo determinado, como nos contratos de obra certa, de experiência e de safra. Também não afasta a incidência do regime do FGTS a espécie de remuneração percebida pelo empregado, seja fixa ou variável, simples ou mista.

Os empregados públicos ${ }^{41}$ também estão sujeitos ao regime do FGTS, eis que o $\S 1^{\circ}$, do artigo 15 , da Lei $8.036 / 90$, estendeu o conceito de empregador adotado pela legislação trabalhista aos entes da Administração Direta, Indireta ou Fundacional, da União, Estados, Distrito Federal e Municípios. De se notar que nos termos do artigo 19-A, da Lei do FGTS, o empregado público tem direito aos depósitos do FGTS mesmo que o contrato de trabalho seja declarado nulo posteriormente por não observância da regra do concurso público, prevista no artigo $37, \S 2^{\circ}$, da Constituição Federal, desde que mantido o direito ao salário percebido.

Ainda no que tange aos empregados, de se registrar que os rurais, após a

\footnotetext{
${ }^{40}$ A espécie do contrato de trabalho não afasta o direito do empregado ao regime do FGTS, mas pode interferir no percentual de recolhimento ao Fundo, como no caso do contrato de aprendizagem, que nos termos do $\S 7^{\circ}$ do artigo 15 da Lei 8.036/90, incluído pela Lei $\mathrm{n}^{\circ} 10.097 / 00$, terá incidência da contribuição mensal no percentual reduzido de $2 \%$ (dois por cento). Da mesma forma, nos contratos por prazo determinado celebrados com base na Lei 9.601/98, o percentual da contribuição mensal para o Fundo de Garantia é reduzido para $2 \%$ (dois por cento).

${ }^{41} \mathrm{O}$ empregado público, de forma ampla, pode ser entendido como o agente público ocupante de emprego público no âmbito da Administração Pública, que tem vínculo empregatício decorrente de previsão constitucional, seja porque está jungido ao regime jurídico privado das empresas estatais, seja porque foi adotado o regime jurídico único celetista, ou por hipótese de contratação para atender necessidade temporária de excepcional interesse público, em consonância ao artigo 37, inc. IX, da Constituição Federal. In MEIRELLES, Hely Lopes. Direito administrativo brasileiro. 26 a ed. São Paulo: Malheiros, 2001, p. 383/384.
} 
equiparação em direitos com os trabalhadores urbanos e rurais, determinada pelo artigo $7^{\circ}$ da Constituição Federal de 1988, também estão albergados pelo regime do FGTS. Inicialmente a Lei 5.107/66 abarcou apenas os empregados de empresas sujeitas à CLT, e assim, os empregados rurais, então regidos pelo Estatuto do Trabalhador Rural (Lei 4.214/63), não foram alcançados pelo FGTS, nem mesmo após a edição da Lei 5.889/73, que vinculou a aplicação do FGTS à lei especial, nunca editada ${ }^{42}$.

O trabalhador avulso também faz jus ao regime do Fundo de Garantia do Tempo de Serviço, pois embora preste serviços com eventualidade às empresas que necessitam de seu labor apresenta os mesmos direitos do trabalhador com vínculo de emprego, nos termos do inciso XXXIV do artigo $7^{\circ}$, da Constituição Federal. A inclusão do trabalhador avulso no FGTS foi prevista inicialmente na Lei 5.480/68. Como não existe um empregador permanente, os recolhimentos ao Fundo de Garantia, em favor do trabalhador avulso, ficam sob a responsabilidade do órgão gestor de mão-de-obra ou do sindicato intermediador da contratação de seus serviços com as empresas tomadoras.

Encontra-se também no regime do FGTS o trabalhador temporário, contratado por empresa de trabalho temporário para prestar serviços voltados a atender à necessidade transitória de substituição de pessoal regular e permanente ou à acréscimo extraordinário de serviços, nos termos da Lei 6.019/74. A incidência obrigatória, a partir da Constituição Federal de 1988, do trabalhador temporário no sistema do Fundo de Garantia teve o efeito de afastar a aplicação da indenização por dispensa sem justa causa ou término normal do contrato, correspondente a 1/12 (um doze avos) do pagamento recebido, conforme previsto na alínea $f$, do artigo 12 , da citada lei ${ }^{43}$.

Por sua vez, o trabalhador contratado para prestar serviços no exterior também tem direito aos recolhimentos para o Fundo de Garantia do Tempo de Serviço. Cumpre esclarecer que nesta categoria estão abrangidos quaisquer contratações ou transferências de trabalhadores para o exterior ${ }^{44}$.

\footnotetext{
${ }^{42}$ JANTALIA, Fabiano. FGTS - Fundo de Garantia do Tempo de Serviço. Op. cit., p. 82.

${ }^{43}$ MARTINS, Sérgio Pinto. Manual do FGTS. Op. cit., p. 88.

${ }^{44}$ A Lei 7.064/82 teve a redação de seu artigo $1^{\circ}$ modificada pela Lei $n^{\circ} 11.962 / 2009$, para estabelecer que regula, de forma geral, a situação de trabalhadores contratados no Brasil ou transferidos por seus empregadores para prestar serviço no exterior. Assim, não mais se justifica interpretação restrita, no sentido de sua aplicação apenas aos trabalhadores contratados no Brasil, ou transferidos por empresas prestadoras de serviços de engenharia, consultoria, projetos e obras, montagens, gerenciamento e congêneres, para prestar serviços no exterior, consoante redação original.
} 
Uma especificidade com relação a esses trabalhadores transferidos para prestar serviços no exterior é a previsão da Lei 7.064/82, que em seu artigo $9^{\circ}$, determina que o período de duração da transferência será computado no tempo de serviço do empregado para todos os efeitos da legislação brasileira, ainda que a lei local de prestação do serviço considere essa prestação como resultante de um contrato autônomo e determine a liquidação dos direitos oriundos da respectiva cessação. Na hipótese de liquidação, o empregador fica autorizado a deduzir esse pagamento dos depósitos do FGTS, existentes na conta vinculada em nome do empregado, e se o saldo da conta não comportar a dedução, a diferença poderá ser novamente deduzida do saldo dessa conta quando da cessação no Brasil do respectivo contrato de trabalho.

No caso dos técnicos estrangeiros domiciliados ou residentes no exterior para execução de serviços especializados no Brasil, em caráter provisório, o artigo $1^{\circ}$, do Decreto-Lei 691/69, determinou inaplicabilidade, dentre outros, do disposto na Lei $\mathrm{n}^{\mathrm{o}}$ 5.107/66, com as alterações do Decreto-Lei $n^{\circ}$ 20/66 e legislação subseqüente. Entretanto, de se aplicar a disposição do artigo 15 da Lei 8.036/90, que determina obrigatoriedade de depósito do FGTS a todo empregador ${ }^{45}$. Ora, os estrangeiros somente não gozam dos mesmos direitos assegurados aos brasileiros quando a própria Constituição autorize esta distinção ${ }^{46}$, e não há restrição nesse sentido quanto aos direitos sociais estabelecidos no seu artigo $7^{\circ}$. A base de incidência do FGTS nesta hipótese dos técnicos estrangeiros deve abarcar a remuneração no Brasil e no exterior.

Há também incidência do sistema do Fundo de Garantia do Tempo de Serviço na relação de emprego do treinador profissional de futebol, o qual, nos termos do artigo $2^{\circ}$, da Lei 8.650/93, é considerado empregado quando especificamente contratado por clube de futebol ou associação desportiva, com finalidade de treinar atletas de futebol profissional ou amador, ministrando-lhes técnicas e regras de futebol com objetivo de assegurar-lhes conhecimentos táticos e técnicos suficientes para a prática desse esporte.

No mesmo sentido, o atleta profissional de todas as modalidades faz jus ao Fundo de Garantia do Tempo de Serviço, uma vez que a Lei 9.615/98 (Lei Pelé) determina aplicação das normas gerais da legislação do trabalho e da seguridade social, bem como, em seu artigo $31, \S 1^{\circ}$, especificamente, se refere à rescisão do contrato de

\footnotetext{
${ }^{45}$ MARTINS, Sérgio Pinto. Manual do FGTS. Op. cit., p. 94.

${ }^{46}$ SILVA, José Afonso da. Curso de direito constitucional positivo. São Paulo: Malheiros, 2006, p.341.
} 
trabalho pelo atleta profissional diante do não recolhimento das parcelas do FGTS por período igual ou superior a três meses.

$\mathrm{Na}$ esteira da classificação adotada linhas acima, a respeito dos grupos obrigatórios e facultativos no regime do FGTS, cumpre tecer algumas considerações quanto a esses últimos, consubstanciados nos empregados domésticos e nos diretores não empregados.

A possibilidade de se conceder o direito ao FGTS aos domésticos somente se deu com a edição da Lei 7.839/89, cuja mesma previsão foi transposta na posterior Lei 8.036/90, a qual, em seu artigo $15, \S 3^{\circ}$, estabeleceu que "os trabalhadores domésticos poderão ter acesso ao regime do FGTS, na forma que vier a ser prevista em lei". Com a edição da Lei 10.208/01, que incluiu o artigo $3^{\circ}$-A na Lei 5.859/72, essa possibilidade tornou-se factível, deixando-se, entretanto, ao empregador a faculdade de inserir o trabalhador doméstico no regime FGTS.

Nos termos do Decreto $\mathrm{n}^{\mathrm{o}} 3.361 / 00$, o recolhimento do FGTS do empregado doméstico passa a ser obrigatório a partir do recolhimento do primeiro depósito na conta vinculada, quando o empregador terá de fazer mensalmente o recolhimento, no percentual de $8 \%$ a ser calculado sobre a remuneração mensal do empregado doméstico. A inclusão é irretratável e irrevogável em relação a esse vínculo empregatício.

Por seu turno, é também facultativa a inclusão de diretor não empregado no regime do Fundo de Garantia do Tempo de Serviço pela empresa, conforme expressa previsão do artigo 16, da Lei 8.036/90, que define como diretor aquele que exerce cargo de administração previsto em lei, estatuto ou contrato social, independente da denominação do cargo $^{47}$.

Importa ressaltar que os estagiários não integram o sistema do FGTS, e não fazem jus aos depósitos mensais ou rescisório vinculados, eis que, nos termos do artigo $3^{\circ}$, da Lei $11.788 / 08$, o estágio não cria vínculo empregatício de qualquer natureza quando observados os requisitos estabelecidos na citada lei reguladora.

\footnotetext{
${ }^{47}$ A doutrina aponta uma extensão teleológica do alcance do dispositivo citado, no sentido de que não apenas os diretores de sociedade anônima podem ser incluídos no regime do FGTS, mas qualquer pessoa física que exerça administração com efetivo poder de mando em qualquer espécie de sociedade, associação, sindicato e fundações, inclusive empresas públicas, sociedades de economia mista e fundações públicas. In JANTAIA, Fabiano. FGTS - Fundo de Garantia do Tempo de Serviço. Op. cit., p. 89.
} 
Feita a abordagem sobre trabalhadores que têm direito ao regime do Fundo de Garantia do Tempo de Serviço passam-se às considerações sobre empregadores sujeitos ao mesmo regime.

Como tratado alhures, são diversas as teorias jurídicas que se ocupam de explicar a natureza jurídica dos recursos do FGTS em relação ao empregador no que tange à obrigação principal de realizar depósito mensal ou rescisório na conta vinculada do empregado. De toda forma, sem aprofundar nos debates, é de se recordar que o Supremo Tribunal Federal firmou entendimento, adotado no presente trabalho, no sentido de que a contribuição recolhida pelo empregador ao FGTS deflui do fato de ser ele o sujeito passivo da obrigação, de natureza trabalhista e social, que encontra, na regra constitucional a sua fonte $^{48}$.

Nos termos do artigo 15, da Lei 8.036/90, todos os empregadores são obrigados a depositar até o dia 7 (sete) de cada mês em conta bancária vinculada, na Caixa Econômica Federal, a importância correspondente a 8\% (oito por cento) da remuneração paga ou devida no mês anterior a cada trabalhador. A alíquota é diferenciada, com redução para $2 \%$ (dois por cento), nas hipóteses de contratos de aprendizagem, bem como na contratação por prazo determinado nos moldes da Lei 9.601/98.

No conceito de remuneração para fins do FGTS incluem-se todas as parcelas de que tratam os artigos 457 e 458 da CLT e a gratificação natalina (décimo terceiro salário) a que se refere a Lei $n^{0} 4.090 / 62$, com as modificações da Lei $n^{0}$ 4.749/65.

Por sua vez, o $\S 1^{\circ}$, do artigo 15 , da citada lei, estabelece um conceito elástico de empregador, considerando toda a pessoa física ou pessoa jurídica, de direito privado ou de direito público, da Administração Pública Direta, Indireta ou Fundacional, de quaisquer dos Poderes, da União, dos Estados, do Distrito Federal e dos Municípios, que admitir trabalhadores a seu serviço e também aquele que, regido por legislação especial, encontrar-se nessa condição ou figurar como fornecedor ou tomador de mão-deobra, independente da responsabilidade solidária ou subsidiária a que eventualmente venha a obrigar-se.

Segundo Fabiano Jantalia "o conceito adotado pela lei do FGTS é

${ }^{48}$ STF, Tribunal Pleno, RE 100.249/SP, Rel. Min. Néri da Silveira, DJ 1. .o.7.1988. 
bastante amplo, marcado por duas características importantes: a abstração da forma jurídica do empregador e a irrelevância do tipo de contrato que rege a relação de

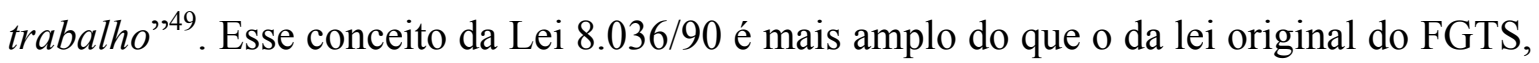
Lei 5.107/66, que submetia ao regime do Fundo de Garantia apenas as empresas sujeitas à Consolidação das Leis do Trabalho.

Pela amplitude do conceito de empregador utilizado pela Lei do FGTS nele se enquadram também as associações, fundações públicas e privadas, sindicatos, partidos políticos, organizações religiosas pessoas jurídicas estrangeiras, os condomínios edilícios de unidades residenciais que admitirem trabalhadores a seu serviço, bem como as pessoas físicas e profissionais liberais que utilizarem mão-de-obra subordinada mediante contratação de empregados.

O empregador rural passou a ter obrigação de recolher as contribuições para o FGTS a partir da Lei 7.839/90, pois a Constituição Federal de 1988 não mais fez restrição quanto à abrangência do FGTS apenas aos empregadores sujeitos à CLT.

O empregador doméstico não se encontra obrigado a recolher a contribuição para o FGTS, sendo o regime facultativo, nos termos do artigo $3^{\circ}$-A, da Lei 5.859/72, que estabelece que "é facultada a inclusão do empregado doméstico no Fundo de Garantia do Tempo de Serviço - FGTS, de que trata a Lei no 8.036, de 11 de maio de 1990, mediante requerimento do empregador, na forma do regulamento".

Ressalte-se ainda que as entidades filantrópicas também estão obrigadas ao recolhimento das contribuições para o Fundo de Garantia do Tempo de Serviço com relação aos seus empregados, sejam os recolhimentos mensais ou rescisórios, não mais vigorando a distinção ${ }^{50}$ feita outrora quanto à forma de pagamento dos valores do FGTS.

\footnotetext{
${ }^{49}$ JANTALIA, Fabiano. FGTS - Fundo de Garantia do Tempo de Serviço. Op. cit., p. 92.

${ }^{50}$ O Decreto-lei n ${ }^{\circ} 194$, de 24 de fevereiro de 1967, facultou às entidades de fins filantrópicos a dispensa de efetuar os depósitos do FGTS com relação a todos os seus empregados, ou com relações aos seus empregados que não optarem pelo regime. Entretanto, determinava que nos casos de extinção ou rescisão do contrato de trabalho, inclusive no de aposentadoria concedida pela previdência social, as entidades que tenham ficado isentas de depósitos, tinham o dever de pagar, diretamente ao seu empregado optante ou não
} 


\subsection{O FGTS como direito trabalhista autônomo}

De modo geral não são frequentes as ações trabalhistas ajuizadas pelos trabalhadores voltadas específica e unicamente para a cobrança das contribuições do Fundo de Garantia do Tempo de Serviço não recolhidas ou recolhidas a menor pelo empregador, especialmente o ajuizamento da ação durante a vigência do contrato de trabalho.

O que se verifica é a cobrança das contribuições relativas ao Fundo de Garantia como verbas acessórias em ações ajuizadas com vistas ao recebimento de diferenças salariais, aviso prévio, horas extras, gratificações, dentre outras parcelas remuneratórias inadimplidas pelo empregador, sendo cumulado o pedido de pagamento das correspondentes parcelas do FGTS incidentes sobre tais verbas trabalhistas, e quase na maioria das vezes após a cessação do contrato de trabalho.

Sobre os fatores responsáveis pela resistência no ajuizamento das ações trabalhistas especialmente durante a vigência do contrato de trabalho, merece transcrição as conclusões de Vera Lúcia Ferrante, em pesquisa científico-social que abarca o tema, no seguinte sentido:

[...] a morosidade e excesso de burocratização exigidos na Justiça do Trabalho; o temor de ser perseguido pelo patrão ou não encontrar mais emprego depois de ter encaminhado formalmente uma certa reclamação; a convicção, que não é típica da maioria, de que o poderio econômico do empresário pesará para que a solução judicial seja favorável aos seus interesses. Quando tais resistências são superadas e o empregado se empenha numa causa trabalhista, ele o faz pensando em conseguir vantagens imediatas, de caráter financeiro. Geralmente, o empregado prefere aceitar acordos, mesmo que lhe sejam prejudiciais, para não se dispor a esperar o fim de um processo trabalhista, correndo o risco de ser marginalizado da estrutura operacional ${ }^{51}$.

Por sua vez, é passível de crítica a cobrança das contribuições para o Fundo de Garantia do Tempo de Serviço levada a efeito sob a epígrafe de verbas

optante, com menos de um ano de serviço, quantia igual ao depósito bancário, com correção monetária e juros.

${ }^{51}$ FERRANTE, Vera Lúcia Silveira Botta. FGTS: ideologia e repressão. São Paulo: Ática, 1978, p. 318. 
trabalhistas acessórias.

A regra de que o acessório segue o principal merece uma releitura doutrinária diante da identificação do FGTS como um direito autônomo do trabalhador, que decorre do contrato de trabalho e não das verbas salariais que lhe servem de base de incidência, de modo que a prescrição dos valores correspondentes aos demais direitos trabalhistas que compõem a base de cálculo do FGTS não afasta sua exigibilidade. Segundo Caio Mario da Silva Pereira, “o bem acessório, pela sua própria existência subordinada, não tem nesta qualidade, uma valoração autônoma, mas liga-se-lhe o objetivo de completar, como subsidiário, a finalidade econômica da coisa principal" ${ }^{, 52}$.

A essência do bem acessório como subsidiário não se aplica ao FGTS, pois este não é subordinado à remuneração no sentido técnico definido pela doutrina civilista. Pelo contrário, o FGTS é direito autônomo, havendo inclusive hipóteses em que a contribuição para o Fundo de Garantia deve ser recolhida independentemente de pagamento de verbas salariais, a exemplo do período em que o empregado se encontra afastado por motivo de acidente do trabalho e prestação do serviço militar.

O inciso III, do artigo $7^{\circ}$, da Constituição Federal de 1988, determina que o FGTS é direito dos trabalhadores urbanos e rurais, sem qualquer vinculação aos demais direitos trabalhistas ou parcelas remuneratórias que lhe servem de base de incidência e cálculo. A legislação ordinária determina expressamente que os créditos relativos ao FGTS gozam dos mesmos privilégios atribuídos aos créditos trabalhistas, consoante se extrai do artigo $2^{\circ}, \S 3^{\circ}$, da Lei 8.844/94, sem estabelecer acessoriedade.

A autonomia do FGTS em relação ao conjunto dos direitos sociais trabalhistas pode ser identificada em âmbito que ultrapassa o dogmatismo jurídico, fazendo-se necessário compreender "as decisões do legislador político como efetivação do sistema de direitos, e suas politicas como configuração desse mesmo sistema", 53

No campo dos fatos, considerados os espectros multicutural e pluralista da sociedade brasileira, o atrelamento das contribuições do Fundo de Garantia do Tempo de Serviço como acessório de outros direitos trabalhistas de natureza remuneratória

\footnotetext{
${ }^{52}$ PEREIRA, Caio Mario da Silva. Instituições de Direito Civil. Rio de Janeiro: Aide, 1987, p. 376.

${ }^{53}$ HABERMAS, Jürgen. A inclusão do outro - estudos de teoria política. $1^{\mathrm{a}}$ ed. Trad. George Sperber and Paulo Astor Soethe. São Paulo: Edições Loyola, 2002, p. 245.
} 
termina por trazer desafio à congruência dogmática e à efetividade dos valores e finalidades albergadas pelo instituto do FGTS.

O Fundo de Garantia deve ser tomado como um direito fundamental e autônomo do trabalhador, em cumprimento das finalidades constitucionais de possibilitar a formação de um pecúlio para compensação do seu tempo de serviço, e de configurar o regime de indenização por dispensa arbitrária ou sem justa causa, nos termos do artigo $7^{\circ}$, I, da Constituição Federal, combinado com o artigo 10, I, do respectivo ADCT. Além disso, inolvidável que está presente também o interesse econômico-social na recuperação dos créditos do FGTS para atender outro campo de finalidades legais, atinentes ao financiamento de programas de habitação popular, saneamento básico e infra-estrutura urbana.

As presentes considerações levam à revisitação do FGTS como objeto de ação trabalhista para qualificá-lo sob o ponto de vista do trabalhador, como objeto de pedido autônomo, o que também reflete positiva e diretamente na alteração interpretativa quanto à aplicação da prescrição trabalhista aos créditos do FGTS, tratado abaixo em tópico específico.

\subsection{O Fundo de Garantia do Tempo de Serviço e a ação trabalhista}

\subsubsection{Competência da Justiça do Trabalho}

A delimitação do tema analisado no presente capítulo circunscreve o FGTS como objeto do pedido em ação trabalhista, no que tange à cobrança dos respectivos recolhimentos mensais e rescisórios determinados pela legislação. 
O artigo 26, da Lei 8.036/90, estabelece expressamente a competência da Justiça do Trabalho para julgar os dissídios entre os trabalhadores e os empregadores no quanto às obrigações impostas pela lei em relação ao Fundo de Garantia do Tempo de Serviço, mesmo quando a Caixa Econômica Federal e o Ministério do Trabalho e Emprego (União) figurarem como litisconsortes.

Considerando o espectro tridimensional das relações travadas em relação ao Fundo de Garantia do Tempo de Serviço, quais sejam, a relação entre as partes da relação de trabalho, a relação entre o Estado e o empregador, e a relação entre o Estado e o empregado, tem-se que a determinação do artigo 26, da Lei 8.036/90, cinge-se aos limites da primeira hipótese dos vínculos considerada.

Com efeito, as questões e litígios que possam surgir entre as partes da relação de trabalho devem ser conhecidas e julgadas pela Justiça do Trabalho, nos termos do inciso I, do artigo 114, da Constituição Federal, com redação dada pela Emenda Constitucional $\mathrm{n}^{\mathrm{o}} 45$, de 2004, o qual determina competir à Justiça do Trabalho processar e julgar as ações oriundas da relação de trabalho.

Assim, as pretensões que se relacionarem com o descumprimento ou inobservância das regras e princípios estabelecidos pela Lei do FGTS, considerado o vínculo entre as próprias partes da relação de trabalho, devem ser deduzidas em ação trabalhista perante o órgão competente da Justiça do Trabalho, consoante artigo 114, I, da Constituição Federal, combinado com o caput do artigo 26 da Lei 8.036/90.

Dessa forma, a cobrança pelo trabalhador dos depósitos mensais e rescisório relativos ao FGTS, não recolhidos ou recolhidos a menor pelo empregador, integra o rol das pretensões a serem buscadas no âmbito da Justiça do Trabalho por meio das ações trabalhistas.

\subsubsection{Estrutura processual de cobrança judicial do FGTS pelo} trabalhador 
modelo de cobrança das contribuições mensais e rescisórias referentes ao FGTS em sede de ação trabalhista, analisando-se os legitimados e o respectivo iter procedimental.

Tratando-se de ação trabalhista para cobrança das contribuições do FGTS a relação jurídica processual que se estabelece é entre o trabalhador no pólo ativo da demanda e o empregador no pólo passivo.

Segundo o caput do artigo 25, da Lei 8.036/90, o próprio trabalhador, seus dependentes e sucessores, ou ainda o Sindicato a que estiver vinculado, poderão acionar diretamente a empresa por intermédio da Justiça do Trabalho para compeli-la a efetuar o depósito das importâncias relativas ao FGTS.

Os trabalhadores legitimados à cobrança dos créditos relativos ao FGTS são aqueles que fazem jus ao regime do Fundo de Garantia, conforme tratado alhures. Por sua vez, o empregador legitimado passivamente à demanda trabalhista promovida pelo trabalhador para cobrança das contribuições do FGTS é aquele que se enquadra no conceito amplo determinado pelo $\S 1^{\circ}$, do artigo 15 , da Lei 8.036/90.

O sindicato da categoria profissional também está legitimado a ajuizar ações trabalhistas para cobrança dos recolhimentos ao FGTS, segundo expressa disposição do artigo 25, da Lei 8.036/90. Nesta hipótese, tem-se presente a legitimação extraordinária caracterizada pela substituição processual ${ }^{54}$, prevista no artigo $8^{\circ}$, III, da Constituição Federal, que determina caber ao sindicato a defesa dos direitos e interesses coletivos ou individuais da categoria, inclusive em questões judiciais ou administrativas ${ }^{55}$.

Ainda no âmbito da legitimidade, é indubitável que a União tem legitimidade para figurar como interveniente nos processos que cuidam da recuperação dos créditos do Fundo de Garantia do Tempo de Serviço, uma vez que existe um potencial interesse econômico no deslinde dos feitos do $\mathrm{FGTS}^{56}$, pois, nos termos do $\S 4^{\circ}$, do artigo

\footnotetext{
${ }^{54}$ No mesmo sentido NASCIMENTO, Amauri Mascaro. Comentários às leis trabalhistas. São Paulo: LTr, 1991, p.40; TEIXEIRA FILHO, João de Lima. Instituições de direito do trabalho. 14 ed. São Paulo: LTr, 1993, p. 603; e OLIVEIRA, Francisco Antonio de. Comentários às súmulas do TST. $7^{\mathrm{a}}$ ed. São Paulo: Revista dos Tribunais, 2007, p. 584.

${ }^{55}$ O Supremo Tribunal Federal, com base no artigo $8^{\circ}$, III, da Constituição Federal, reconhece a legitimidade extraordinária dos sindicatos para defender em juízo os direitos e interesses coletivos ou individuais dos integrantes da categoria que representam, abrangendo a liquidação e a execução dos créditos reconhecidos aos trabalhadores, e por se tratar de típica hipótese de substituição processual é desnecessária qualquer autorização dos substituídos. (STF - RE 193.503/SP, Pleno - Rel. Min. Carlos Velloso - DJU 1 24.08.2007).

${ }^{56}$ JANTALIA, Fabiano. FGTS - Fundo de Garantia do Tempo de Serviço. Op. cit., p. 169.
} 
13, da Lei 8.036/90, o saldo das contas vinculadas é garantido pelo Governo Federal, o que faz incidir a regra do parágrafo único do artigo $5^{\circ}$, da Lei 9.469/97, segundo a qual as pessoas jurídicas de direito público poderão intervir nas causas cuja decisão possa ter reflexos de natureza econômica, ainda que indiretos, e, independentemente da demonstração de interesse jurídico, para esclarecer questões de fato e de direito, podendo juntar documentos e memoriais reputados úteis ao exame da matéria e, se for o caso, recorrer, hipótese em que, para fins de deslocamento de competência, serão consideradas partes.

Numa análise apressada a possibilidade de intervenção da União, se efetivamente levada a efeito em sede de uma ação trabalhista movida pelo trabalhador com fulcro no artigo 26, da Lei 8.036/90, pode revelar antinomia legislativa. O parágrafo único, do artigo $5^{\circ}$ da Lei 9.469/97, determina que a União será considerada parte para fins de deslocamento de competência. Nos termos do artigo 26, da Lei 8.036/90, combinado com artigo 114, I da, Constituição Federal, a competência para a demanda judicial de cobrança dos recolhimentos para o FGTS pelo trabalhador em face do empregador é da Justiça do Trabalho. Entretanto, o aparente conflito desta norma com parágrafo único do artigo $5^{\circ}$, da Lei 9.469/97, esmaece pela ressalva final do artigo 109, I, da Constituição Federal, que determina competir à Justiça Federal o julgamento das causas em que a União, entidade autárquica ou empresa pública federal forem interessadas na condição de autoras, rés, assistentes ou oponentes, exceto as de falência, as de acidentes de trabalho e as sujeitas à Justiça Eleitoral e à Justiça do Trabalho.

Ultrapassadas as questões relativas à legitimidade processual quanto às ações trabalhistas que visam ao recolhimento das contribuições do Fundo de Garantia do Tempo de Serviço, requer breve abordagem o procedimento sobre o qual se desenvolve o processo judicial de recuperação dos créditos do FGTS pelo próprio trabalhador.

O processo de reconhecimento dos créditos relativos ao FGTS, e em especial sua respectiva execução, enfrentam os mesmos abalos de eficácia a que estão submetidas as demandas trabalhistas no atual estágio do processo do trabalho.

Para o âmbito deste trabalho, far-se-á o necessário relato sobre o rito 
processual a ser seguido nos dissídios individuais ${ }^{57}$ movidos pelo trabalhador em face do empregador, posto ser o mesmo a ser seguido, dentre outros, para fins do pleito de pagamento das contribuições do Fundo de Garantia do Tempo de Serviço.

No âmbito do processo do trabalho pode-se organizar os procedimentos em dois grandes grupos: procedimento ordinário e procedimentos especiais, deste fazendo parte os procedimentos sumário, sumaríssimo, inquérito judicial, e também as medidas cautelares e especiais do Código de Processo Civil e legislação processual extravagante.

De interesse à presente investigação a Consolidação das Leis do Trabalhos estabelece a partir do artigo 837 os ritos processuais dos dissídios individuais, representados pelos procedimentos ordinário, sumário e sumaríssimo.

O rito ordinário possibilita discussão ampla do litígio pelas partes, pois apresenta cognição completa, por meio da qual "o devido processo legal encontra a mais dilatada de suas formas procedimentais, e aquela que melhor propicia a reconstituição completa dos fatos, bem como os debates em torno das várias facetas do litígio "58. Dessa forma, o procedimento ordinário é aquele que concentra o maior número de atos e prazos em relação aos ritos sumário e sumaríssimo, identificado pelas fases postulatória, probatória, decisória e com ampla possibilidade recursal.

De outro lado, o procedimento sumaríssimo, regulado pelos artigos 852A a 852-I da Consolidação das Leis do Trabalho, instituído pela Lei $\mathrm{n}^{\circ}$ 9.957/00, tem grande importância no processo do trabalho, vez que, a ele estão submetidas os dissídios individuais que apresentem pedido certo ou determinado, com o respectivo valor correspondente e que não exceda a quarenta vezes o salário mínimo. O procedimento sumaríssimo é um rito especial criado para solução de dissídios individuais de baixo valor, e está atrelado "ao princípio da celeridade processual, implementado pela redução das formalidades, das provas e a ampliação da liberdade do juiz para a condução do processo, tudo visando solução o quanto possível rápida ${ }^{\text {,59. }}$.

\footnotetext{
${ }^{57}$ Sobre a nomenclatura dissídio individual, no processo do trabalho, é comum serem utilizadas como sinônimas as expressões dissídio trabalhista, ação trabalhista, reclamação trabalhista, que expressam a ação individual intentada pelo trabalhador em face do empregador. In MARTINS, Sérgio Pinto. Direito Processual do Trabalho. São Paulo: Atlas. 2004, p. 237.

${ }^{58}$ MARQUES, Frederico. Direito Processual do Trabalho. São Paulo: Atlas, 2002, p. 24.

${ }^{59}$ NASCIMENTO, Amauri Mascaro. Curso de Direito Processual do Trabalho. São Paulo: Saraiva, 2007, p. 741.
} 
No rito sumaríssimo as matérias que não foram especificamente regulamentadas pelo legislador seguem as diretrizes do procedimento do rito ordinário. Importante destacar que não podem se valer do procedimento sumaríssimo, por exclusão legal (artigo 852-A, CLT), a Administração Pública Direta, Autárquica e Fundacional, da União, Estados, Distrito Federal e Municípios.

Por fim, o rito sumário do processo trabalhista, instituído pela Lei $\mathrm{n}^{\circ}$ $5.584 / 70$ (artigo $2^{\circ}, \S \S 3^{\circ}$ e $4^{\circ}$ ), destina-se às ações cujo valor da causa não ultrapasse duas vezes o salário mínimo vigente na data de ajuizamento da ação. O procedimento também é simplificado visando imediata solução da lide.

A doutrina aponta algumas distinções fundamentais entre os ritos sumário e sumaríssimo. No sumaríssimo o pedido é sempre líquido, o número de testemunhas é de até duas, é vedada a citação por edital, a sentença dispensa relatório e apresenta fase recursal mais ampla, sendo que no sumário, o pedido não é obrigatoriamente líquido, o número de testemunhas é de até três, a citação por edital é permitida e prevalece a irrecorribilidade da sentença da vara, salvo matéria constitucional. ${ }^{60}$ Assim como o rito sumaríssimo o rito sumário possui determinadas peculiaridades próprias, sendo aplicado as regras do procedimento ordinário naquilo que não se encontra disposto na Lei 5.584/70.

As ações trabalhistas ajuizadas pelos trabalhadores que têm por objeto o recolhimento das contribuições mensais e rescisórias devidas ao FGTS podem seguir, segundo as diretrizes acima traçadas, o rito ordinário, sumário ou sumaríssimo.

De se ressaltar que o processo do trabalho é permeado pelo princípio conciliatório ou da conciliabiliadade ${ }^{61}$, no sentido de que há uma concentração de esforço do processo trabalhista em priorizar a negociação acima do conflito, de maneira a solucionar as disputas oriundas da relação de trabalho.

As verbas relativas ao FGTS não podem ser objeto de renúncia ou transação pelo empregado, não somente pela indisponibilidade de direitos trabalhistas, mas porque também têm destinação legal sócio-econômica quanto ao financiamento dos

\footnotetext{
${ }^{60}$ NASCIMENTO, Amauri Mascaro. Curso de Direito Processual do Trabalho. Op. cit., p. 742/743.

${ }^{61}$ PINTO, José Augusto Rodrigues. Processo trabalhista de conhecimento. $7^{\mathrm{a}}$ ed. São Paulo: LTr, 2005, p. 24.
} 
programas públicos de habitação popular, saneamento básico e infraestrutura urbana.

Diante da sentença que julgar procedente o pedido relacionado ao recolhimento das parcelas relativas às contribuições do Fundo de Garantia do Tempo de Serviço, ou mesmo de acordo ou termo de conciliação judicialmente homologado nesse sentido, e diante do não cumprimento espontâneo pelo devedor, inicia-se a execução do julgado, nos termos dos artigos 876 e seguintes, da CLT, exceto se for ilíquida a sentença exeqüenda, hipótese na qual, nos termos do artigo 879, da Consolidação das Leis do Trabalho, o credor deve ordenar previamente a sua liquidação por cálculos, por arbitramento ou por artigos.

A execução no processo do trabalho tem regra específica que autoriza o juiz promover de ofício a execução, trata-se da disposição constante no artigo 878, da Consolidação das Leis do Trabalho, que determina que a execução poderá ser promovida por qualquer interessado ou ex officio pelo próprio Juiz ou Presidente ou Tribunal competente.

Iniciada a execução o juiz ou presidente do tribunal mandará expedir mandado de citação do executado a fim de que cumpra a decisão ou o acordo no prazo, pelo modo e sob as cominações estabelecidas ou, quando se tratar de pagamento em dinheiro, inclusive de contribuições sociais devidas à União, para que o faça em 48 (quarenta e oito) horas ou garanta a execução, sob pena de penhora.

Assim, se o executado entender que não deve pagar a importância cobrada poderá garantir a execução mediante depósito integral do valor executado, atualizado e acrescido das despesas processuais, ou nomear bens à penhora, observada a ordem preferencial estabelecida no artigo 655, do Código Processual Civil.

Ausente quaisquer desses comportamentos e não paga a importância executada proceder-se-á à penhora forçada.

Uma vez garantida a execução ou penhorados os bens terá o executado 5 (cinco) dias para apresentar embargos de devedor, cabendo igual prazo ao exeqüente para impugnação. A matéria de defesa será restrita às alegações de cumprimento da decisão ou do acordo, quitação ou prescrição da dívida, ou inexigibilidade do título judicial quando fundado em lei ou ato normativo declarados inconstitucionais pelo Supremo Tribunal 
Federal, ou em aplicação ou interpretação tidas por incompatíveis com a Constituição Federal. Anote-se que nos embargos à penhora poderá o executado ou exeqüente impugnar a sentença de liquidação.

A crítica que se aponta no tocante ao procedimento trabalhista para a recuperação dos créditos do FGTS pelo trabalhador no âmbito da Justiça do Trabalho está intimamente ligada ao problema geral da ineficácia do processo de execução trabalhista, a qual alimenta paradigma na elaboração dos mapas de custos da produção capitalista quanto ao descumprimento de obrigações trabalhistas pelo empregador, a estatística de duração de eventual processo trabalhista e a baixa probabilidade de se efetivar a condenação.

As normas processuais do trabalho clamam por reformas estruturais e de fundo que determinem a modernização do sistema, sobretudo para a rápida entrega da prestação jurisdicional e efetividade da proteção do trabalhador ${ }^{62}$.

Em tese de doutoramento Marcos Neves Fava sintetiza com propriedade as origens da crise do processo de execução trabalhista e aponta diversas ações e iniciativas para o enfrentamento da questão.

Segundo o citado pesquisador, as origens da crise do processo de execução trabalhista são estruturais, ontológicas e interpretativas ${ }^{63}$. A crise estrutural ligase aos problemas administrativos e financeiros do Poder Judiciário que resvalam no defasado quadro de recursos materiais e humanos necessários ao desenvolvimento do seu mister. A crise ontológica remete ao caráter fenomenológico da execução trabalhista, tomada sob o ponto de vista da relação custo-benefício, consideradas as tentativas do devedor em resistir ao cumprimento das decisões e utilizar todos os meios processuais disponíveis para retardar o cumprimento da condenação. E por fim, a crise interpretativa refere-se à inadequação de interpretações jurisprudenciais e doutrinárias sobre a aplicabilidade ao processo do trabalho das regras, princípios, finalidades e mecanismos normativos disponíveis no panorama jurídico-processual brasileiro.

As principais conclusões apontadas pelo citado autor para o enfrentamento da crise da execução trabalhista, nos aspectos estruturais, ontológicos e

${ }^{62}$ BELTRAN, Ari Possidonio. Dilemas do trabalho e do emprego na atualidade. Op. cit., p. 176.

${ }^{63}$ FAVA, Marcos Neves. Eficácia da execução trabalhista. Tese (Doutoramento). Faculdade de Direito da Universidade de São Paulo, 2009, p. 300. 
interpretativos, são: aperfeiçoamento administrativo do Poder Judiciário, racionalidade na distribuição de recursos materiais, padronização de rotina, índices estatísticos, ampliação da responsabilização trabalhista, agilização de diligências por meio de convênios administrativos sobre localização dos devedores e seu patrimônio (Bacenjud, Infoseg, Infojud, Renajud, Cartórios Imobiliários), oneração da dívida, exposição pública do devedor com instituição de certidão negativa de débitos trabalhistas ${ }^{64}$, liquidação de ofício, postura ética do devedor no processo, penas severas pelo não cumprimento das sentenças, arrefecimento do sistema recursal, especialmente quanto aspectos fáticos, aprimoramento da expropriação de bens, antecipação de alienação, aprofundamento da execução provisória e combate às fraudes em execução ${ }^{65}$.

Posto serem observadas na cobrança dos créditos do FGTS pelo trabalhadoras as mesmas regras e princípios da execução trabalhista em geral, todas as medidas acima elencadas refletem positivamente na efetividade da recuperação dos créditos do FGTS pelo trabalhador em ação trabalhista, reforçadas pela criação do Fundo de Garantia das Execuções Trabalhistas, previsto pela Emenda Constitucional no 45/04.

\subsubsection{Notificação da ação trabalhista ao Poder Público}

Estabelece o parágrafo único do artigo 25, da Lei 8.036/90, a obrigatoriedade de notificação à Caixa Econômica Federal e ao Ministério do Trabalho da propositura da ação trabalhista.

\footnotetext{
${ }^{64}$ A Lei 12.440/2011 acrescentou o Título VII-A na Consolidação das Leis do Trabalho, instituindo a Certidão Negativa de Débitos Trabalhistas (CNDT), para comprovar a inexistência de débitos inadimplidos perante a Justiça do Trabalho. O interessado não obtém a referida certidão quando constar o inadimplemento de obrigações estabelecidas em sentença condenatória transitada em julgado proferida pela Justiça do Trabalho ou em acordos judiciais trabalhistas, inclusive no concernente aos recolhimentos previdenciários, a honorários, a custas, a emolumentos ou a recolhimentos determinados em lei; ou o inadimplemento de obrigações decorrentes de execução de acordos firmados perante o Ministério Público do Trabalho ou Comissão de Conciliação Prévia.

${ }^{65}$ FAVA, Marcos Neves. Eficácia da execução trabalhista. Op. cit., p. 301/303.
} 
Importa rememorar que a administração dos recursos do FGTS, como fundo público de natureza social, incumbe à União, nos termos da sua Lei Geral, envolvendo órgãos da sua Administração Direta e Indireta.

Nos termos da Lei 8.036/90 compete à Caixa Econômica Federal o papel de agente operador dos recursos do FGTS, ao passo que, ao Ministério do Trabalho e Emprego é atribuído, pelo artigo 23 da citada lei, a tarefa de verificar, em nome da Caixa Econômica Federal, o cumprimento das regras do FGTS, especialmente quanto à apuração dos débitos e das infrações praticadas pelos empregadores ou tomadores de serviço, competindo-lhe notificar-lhes para efetuarem e comprovarem os depósitos correspondentes e cumprirem as demais determinações legais, podendo, para tanto, contar com o concurso de outros órgãos do Governo Federal.

Por sua vez, a Lei 8.844/94 estabelece a competência do Ministério do Trabalho para realizar a fiscalização e a apuração das contribuições ao Fundo de Garantia do Tempo de Serviço, bem como a aplicação das multas e demais encargos devidos ao Fundo, obrigando a Caixa Econômica Federal o dever de prestar ao Ministério do Trabalho as informações necessárias ao desempenho dessas atribuições.

Dessa forma, a obrigatoriedade de notificação da propositura de ação trabalhista, determinada pelo parágrafo único do artigo 25, da Lei Geral do FGTS, tem por objetivo levar ao conhecimento do Poder Público Federal, especificamente nas figuras do Ministério do Trabalho e Emprego e da Caixa Econômica Federal, a notícia sobre a existência de demanda na Justiça do Trabalho que poderá ensejar a condenação do empregador ao recolhimento das contribuições relativas ao Fundo de Garantia do Tempo de Serviço, viabilizando o exercício das citadas atribuições de fiscalização e apuração dos valores referentes às parcelas do FGTS a serem depositadas pelo empregador.

Todavia, a notificação à Caixa Econômica Federal e ao Ministério do Trabalho e Emprego não tem sido providência observada pela Justiça do Trabalho, especialmente sob o fundamento de que a cobrança dos créditos de FGTS decorrentes da condenação trabalhista desenvolve-se em execução no âmbito do próprio Judiciário trabalhista, e "a falta de notificação à Caixa Econômica Federal nos processos em que se pede pagamento de diferenças do FGTS não gera a nulidade do processo, por falta de 
amparo legal"66.

Inobstante o apontado posicionamento da jurisprudência brasileira a determinação da notificação à Caixa Econômica Federal e ao Ministério do Trabalho e Emprego sobre o ajuizamento de ação trabalhista é ordem legal que não pode ser descumprida pelo Judiciário, especialmente por estar atrelada à finalidade pública e social do Fundo de Garantia do Tempo de Serviço, por constituir em mecanismo instituído para preservar e garantir o exercício das competências dos órgãos administradores do FGTS determinadas na Lei 8.036/90, e ainda, por ser medida no sentido de evitar a propositura de uma execução fiscal pela Procuradoria-Geral da Fazenda Nacional objetivando a cobrança paralela dos mesmos créditos, em franco delineamento de problemas de litispendência, deslocamento de competência e decisões díspares em torno do mesmo objeto em juízo.

Esclareça-se que a notificação não tem o objetivo de determinar o ingresso da Caixa Econômica Federal ou da União, esta como pessoa jurídica a qual se vincula o Ministério do Trabalho e Emprego, na ação trabalhista promovida pelo trabalhador, uma vez que poderia gerar a celeuma de se determinar o deslocamento da competência da Justiça do Trabalho para a Justiça Federal, nos termos do artigo 109, I, da Constituição Federal, o que não pretende.

Sérgio Pinto Martins entende que o ideal seria que se realizasse a notificação da Caixa Econômica Federal e do Ministério do Trabalho e Emprego quando do trânsito em julgado da decisão em ação trabalhista, pois haveria a certeza sobre serem devidos ou indevidos os recolhimentos referentes ao FGTS $^{67}$.

A providência adequada é que o Judiciário cumpra a obrigatoriedade legal da notificação à CEF e ao MTE sobre o ajuizamento da ação trabalhista, e cumule, por interpretação extensiva do dispositivo do parágrafo único, do artigo 25 , da Lei 8.036/90, a notificação de decisão judicial condenatória.

Com efeito, a partir da notificação do Ministério do Trabalho e Emprego sobre o ajuizamento de ação trabalhista em face do empregador, com pedido de recolhimento de valores referentes ao FGTS, será possível que se instaure um

${ }^{66}$ TST, 2 $2^{\mathrm{a}}$ Turma, RR 536368-87.1999.5.07.5555, Rel. Min. José Luciano de Castilho Pereira, DJ 24.09.1999.

${ }^{67}$ MARTINS, Sérgio Pinto. Manual do FGTS. Ob. cit., p. 246. 
procedimento de verificação e fiscalização em relação à empresa ré, com vistas à determinação de eventuais recolhimentos do FGTS em relação aos demais trabalhadores contratados pela mesma empresa que não são partes da ação notificada.

Obviamente que em cumprimento aos objetivos da regra do parágrafo único, do artigo 25, da Lei 8.036/90, e para evitar a litispendência, o Ministério do Trabalho e Emprego, devidamente notificado de uma ação trabalhista não deverá determinar ao empregador réu na ação trabalhista o recolhimento das parcelas do FGTS correspondentes ao litígio, estando, por decorrência, afastada a possibilidade de cobrança dos mesmos créditos em execução fiscal pela Procuradoria-Geral da Fazenda Nacional, uma vez que sem a prévia constituição do crédito de FGTS pelo Ministério do Trabalho inexiste o correspondente título executivo líquido, certo e exigível.

Com o do trânsito em julgado da sentença condenatória trabalhista ou homologação judicial de acordo de outras verbas trabalhistas entabulado entre o trabalhador e o empregador no curso do processo judicial, a intimação do Ministério do Trabalho e da Caixa Econômica Federal, como órgãos de administração do Fundo, resulta providência necessária para fins de cientificar e delimitar as providências de físcalização, apuração e cobrança dos créditos do FGTS pelo Poder Público em face da empresa demandada.

\subsection{Prescrição trintenária e a Justiça do Trabalho}

O tratamento dado ao FGTS no âmbito da Justiça do Trabalho é eminentemente pautado pela sua natureza jurídica de direito trabalhista, associando-o a uma indenização ou compensação pelo tempo de serviço, premiação diferida no tempo ou 
mesmo uma forma de pecúlio forçado em nome do trabalhador ${ }^{68}$.

Adotando-se a natureza jurídica híbrida do Fundo de Garantia do Tempo de Serviço construiu-se nos Tribunais brasileiros uma situação de difícil aceitação à luz dos princípios jurídicos da unidade do direito e da lógica, em prejuízo de uma interpretação favorável ao trabalhador.

Trata-se da situação da prescrição dos créditos do FGTS em face do empregado.

Com efeito, na seara trabalhista a prescrição é regida pelo quanto estabelecido no artigo $7^{\circ}$, XXIX, da Constituição Federal de 1988, com redação dada pela Emenda Constitucional $n^{\circ} 28$, de 25/05/2000, no seguinte sentido:

Artigo $7^{\circ}$ São direitos dos trabalhadores urbanos e rurais, além de outros que visem à melhoria de sua condição social: (...)

XXIX - ação, quanto aos créditos resultantes das relações de trabalho, com prazo prescricional de cinco anos para os trabalhadores urbanos e rurais, até o limite de dois anos após a extinção do contrato de trabalho; (...)

Dessa forma, na vigência do contrato de trabalho, a prescrição dos créditos trabalhistas se dá pelo decurso do prazo de cinco anos, contados a partir da ciência pelo trabalhador da violação a seu direito, segundo a teoria da actio nata, adotada em diversas oportunidades pelo Tribunal Superior do Trabalho, o qual fixou que "o termo inicial do biênio prescricional previsto no artigo 11, da Consolidação das Leis do Trabalho, coincide com a ciência do empregado do prejuízo sofrido, quando nasce o direito de ação para buscar a reparação do direito violado ${ }^{, 69}$.

A Súmula 308, do Tribunal Superior do Trabalho, traz interpretação da contagem do lapso prescricional no sentido de que a prescrição quinquenal da ação trabalhista alberga as pretensões imediatamente anteriores a cinco anos do ajuizamento da ação trabalhista e não da extinção contratual, respeitada a prescrição bienal.

\footnotetext{
${ }^{68}$ SILVA, Homero Batista Mateus da. Curso de Direito do Trabalho Aplicado. Rio de Janeiro: Elsevier, 2009 , p. 370.

69 TST, RR-35018/91.4, Rel. Min. Afonso Celso, DJU 27.11.92, p. 22437. Apud FERRARI, Irany; MARTINS, Melchíades Rodrigues. Julgados Trabalhistas Selecionados. São Paulo, LTr, 1992, v. III, p. 483.
} 
Ainda no que tange ao tema da prescrição, no direito do trabalho a jurisprudência e doutrina fazem distinção entre a prescrição parcial e a prescrição total. No curso do contrato de trabalho o lapso prescricional quinquenal estará sujeito à prescrição parcial na hipótese em que a lesão ao direito atingir prestações sucessivas, fundadas em lei, alcançando-se as verbas vencidas a mais de cinco anos contados do ajuizamento da ação trabalhista. $\mathrm{Na}$ hipótese de prescrição parcial a lesão ao direito renova-se constantemente, sempre que se tornar exigível a prestação quitada indevidamente, surgindo em cada oportunidade de lesão a pretensão e fluência do prazo prescricional ${ }^{70}$.

Por outro lado, na hipótese de alteração contratual por ato negocial, cujo objeto não seja contemplado ou assegurado por preceito legal, incide a regra da prescrição total, pela qual a fluência do lapso prescricional terá origem com a ciência pelo trabalhador da primeira violação do direito. Na hipótese de cessação do contrato de trabalho o seu termo representa o início do lapso prescricional bienal, que por sua própria natureza póstuma ao contrato de trabalho somente admite a prescrição total. Essa orientação consta da Súmula 294, do Tribunal Superior do Trabalho, segundo a qual, "tratando-se de demanda que envolva pedido de prestações sucessivas decorrente de alteração do pactuado, a prescrição é total, exceto quando o direito à parcela esteja também assegurado por preceito de lei".

A prescrição trabalhista quinquenal ou bienal é matéria constitucional (artigo $7^{\circ} \mathrm{XIXX)}$, ao passo que a prescrição total ou parcial é um efeito daquela. Deveras, a prescrição prevista na Constituição Federal é aplicável a todo e qualquer crédito resultante das relações de trabalho, inclusive nas hipóteses previstas na Súmula 294, do TST, sendo que sua aplicação se diferencia apenas quanto aos efeitos.

No tocante aos créditos do Fundo de Garantia do Tempo de Serviço o § $5^{\circ}$, do artigo 23 , da Lei n. 8.036/90, estabelece a regra da prescrição trintenária para o FGTS. De se registrar que a prescrição trintenária dos créditos do FGTS teve origem no artigo 20, da Lei 5.107/66, que determinava a aplicação das regras e privilégios das contribuições devidas à Previdência Social, sendo, na ocasião ${ }^{71}$, o prazo prescricional das

\footnotetext{
${ }^{70}$ BARROS, Alice Monteiro de. Curso de Direito do Trabalho. 5a ed. São Paulo: LTr, 2009, p. 1045/1046.

${ }^{71}$ Ao contrário do FGTS, que, desde a Emenda Constitucional $n^{\circ}$ 8/77, e com interpretação dada pelo Supremo Tribunal Federal (RE100.249-2; RE 117.986-4), teve fixada sua natureza de direito social trabalhista, as contribuições previdenciárias, após a Constituição Federal de 1988, definitivamente integram
} 
contribuições previdenciárias de trinta anos, previsto no artigo 144 da Lei 3.807/60 (Lei Orgânica da Previdência Social - LOPS), referenciado pela Lei 6.830/80 (Lei de Execuções Fiscais - LEF), e repetido nas leis do FGTS no 7.839/89 e no 8.036/90.

Diante desse panorama a Justiça do Trabalho construiu entendimento específico quanto à aplicação aos créditos do FGTS do prazo prescricional determinado pelo artigo $7^{\circ}$, XXIX, da Constituição Federal de 1988 e do prazo trintenário determinado pela lei ordinária, tomando-se como parâmetro a prescrição da pretensão salarial para a incidência do recolhimento da parcela correspondente ao Fundo de Garantia do Tempo de Serviço, sob a parêmia de que o acessório segue o principal $^{72}$.

Essa é a conclusão da Súmula 206, do Tribunal Superior do Trabalho, segundo a qual "a prescrição da pretensão relativa às parcelas remuneratórias alcança o respectivo recolhimento da contribuição para o FGTS". Dessa forma, o recolhimento dos valores devidos ao FGTS fica atrelado ao pagamento das verbas remuneratórias que constituiriam sua base de cálculo, e se tais verbas não foram pagas e não mais existe a possibilidade de cobrança em função da prescrição trabalhista (quinquenal ou bienal), também não será possível cobrança das correspectivas parcelas do Fundo de Garantia, uma vez que não haveria base para incidência e sem o principal não se pode exigir o acessório $^{73}$.

Por sua vez, a prescrição trintenária dos créditos dos trabalhadores relativos ao FGTS segue a diretriz apontada pela Súmula 362, do Tribunal Superior do Trabalho, que fixa o entendimento de que "é trintenária a prescrição do direito de reclamar contra o não-recolhimento da contribuição para o FGTS, observado o prazo de 2 (dois) anos após o término do contrato de trabalho".

Dessa forma, no que diz respeito à prescrição dos recolhimentos do FGTS no âmbito de ação trabalhista é possível diferenciar duas situações: uma na qual o empregador não efetua os depósitos do FGTS, e outra na qual os depósitos são efetuados, restando, contudo, diferenças decorrentes de pagamento a menor ou de parcelas outras não

uma espécie de tributo e se submetem ao prazo prescricional de cinco anos, consoante previsto no artigo 174 do Código Tributário Nacional e declarado pela Súmula Vinculante $n^{\circ} 8$ do Supremo Tribunal Federal.

${ }^{72}$ SILVA, Homero Batista Mateus da. Curso de Direito do Trabalho Aplicado. Op. cit., p. 371.

${ }^{73}$ OLIVEIRA, Francisco Antônio de. Comentários às Súmulas do TST. São Paulo: Revista dos Tribunais, 2007, p. 419. 
pagas no curso da relação de emprego e que compõem sua base de cálculo.

Na primeira situação a prescrição aplicada pela Justiça do Trabalho é a trintenária, consoante entendimento exarado na Súmula 362, do TST, observada a prescrição bienal após a extinção do contrato de trabalho. De outro lado, na segunda situação, o Judiciário trabalhista aplica a prescrição quinquenal prevista no artigo $7^{\circ}$, XXIX, da Constituição Federal de 1988, consoante balizas fixadas pela Súmula 206, do Tribunal Superior do Trabalho, observada também a prescrição bienal após a extinção do contrato de trabalho.

De todo modo, clama-se identificar uma harmonização para o embate entre a conformação dos créditos do FGTS ao histórico prazo prescricional trintenário e ao prazo prescricional trabalhista previsto na vigente Constituição Federal, especialmente por encontrar-se em plano oposto ao tratamento dado à prescrição da recuperação de créditos do FGTS perseguida pela União nas ações de execução fiscal correlatas.

$\mathrm{Na}$ relação entre Estado e empregador, com base no artigo $23, \S 5^{\circ}$, da Lei n. 8.036/90, é observado o prazo prescricional trintenário ${ }^{74}$ da respectiva ação de cobrança dos créditos do FGTS mencionados. A Súmula 210, do Superior Tribunal de Justiça, desde 02.06.1998, fixou entendimento no sentido de que "a ação de cobrança das contribuições para o FGTS prescreve em 30 (trinta) anos"

A dúplice realidade de tratamento quanto ao prazo prescricional para cobrança judicial dos créditos do Fundo de Garantia do Tempo de Serviço estabelecida pelas Súmula 206 e 362, do TST, e pela Súmula 210, do STJ, evidencia questão juridicamente inconciliável diante da possibilidade de cobrança pelo Estado, administrativamente ou em execução fiscal, dos mesmos créditos do FGTS, que à luz da Justiça do Trabalho já se encontra prescrito para o trabalhador.

\footnotetext{
${ }^{74}$ De se advertir sobre divergência, não solucionada, no sentido de que o prazo trintenário do artigo 23 , $\S 5^{\circ}$, da Lei n. 8.036/90, não se impõe na hipótese de cobrança de crédito relativo a FGTS contra a Fazenda Pública, a qual deve observar a prescrição qüinqüenal, no termos do Decreto 20.910/32. Confiram-se os dispositivos: Decreto $n^{\circ}$ 20.910/32: Artigo 1 ${ }^{\circ}$. As dividas passivas da União, dos Estados e dos Municípios, bem como assim todo e qualquer direito ou ação contra a Fazenda federal, estadual ou municipal, seja qual for a sua natureza, prescrevem em cinco anos contados da data do ato ou fato do qual se originaram. Decreto-lei $n^{\circ}$ 4.597/42: Artigo $2^{\circ}$. O Decreto no 20.910, de 6 de janeiro de 1932, que regula a prescrição qüinqüenal, abrange as dividas passivas das autarquias ou entidades e órgãos paraestatais, criados por lei e mantidos mediante impostos, taxas ou quaisquer contribuições, exigidas em virtude de lei federal, estadual ou municipal, bem como a todo e qualquer direito e ação contra os mesmos.
} 
Tome-se como hipótese o caso de empresa que é demandada em ação trabalhista na qual se pleiteia reconhecimento de vínculo empregatício, diferenças de verbas salariais em relação ao piso salarial profissional e correspondentes recolhimentos de parcelas do FGTS, não pagos ao tempo da execução do contrato de trabalho. Se o ajuizamento da ação trabalhista ocorrer após cinco anos dos vencimentos das verbas pleiteadas, ou dos dois anos da extinção do contrato de trabalho, incidirá, na hipótese, a prescrição do direito do trabalho, prevista no artigo $7^{\circ}$, XXIX, da Constituição Federal.

E considerando o entendimento de que a prescrição da pretensão relativa às parcelas remuneratórias alcança o respectivo recolhimento da contribuição para o FGTS (Súmula 206, TST) tem-se que a prescrição trabalhista atingirá também os créditos do Fundo.

De outra sorte, na hipótese de ser a mesma empresa submetida à fiscalização do trabalho obrigatoriamente se fará a verificação de regularidade dos recolhimentos do FGTS e das contribuições sociais. E, diante dessa verificação a fiscalização do trabalho, em procedimento especial para apuração do recolhimento e base de cálculo do FGTS, à vista de documentação que propicie a identificação de empregados em situação irregular, procederá ao levantamento dos débitos do Fundo por recomposição de folha de pagamento e notificará o empregador a recolher a importância devida. Nesse caso, incide a regra da prescrição trintenária previstas no artigo $23, \S 5^{\circ}$, da Lei $n$. 8.036/90, e na Súmula 210, do STJ, e o débito notificado será cobrado pelo Poder Público independentemente do prazo de prescrição trabalhista ou da data de extinção do contrato de trabalho.

Na hipótese considerada, a ação trabalhista ajuizada pelo empregado em face da empresa adota o lapso prescricional trabalhista (quinquenal ou bienal), representando óbice à pretensão de recebimento dos créditos do Fundo de Garantia, ao passo que a sua satisfação poderá decorrer do resultado de uma fiscalização administrativa pelos auditores fiscais do trabalho, mediante o débito individualizado e notificado, uma vez que o Estado conta com prazo para recuperação dos créditos do FGTS de trinta anos, independente da prescrição das verbas trabalhistas que compõem sua base de cálculo. Enfim, restará ao trabalhador a esperança de recuperação de seus créditos pela União ${ }^{75}$.

${ }^{75}$ OLIVEIRA, Francisco Antônio de. Op. cit., p. 418. 
A doutrina trabalhista identifica nessa dualidade de interpretações insegurança jurídica, "pois o empregador não poderá ficar sujeito a não ser acionado pelo empregado, mas ficar sujeito a ter de recolher a contribuição num prazo de 30 anos, caso seja processado pela Procuradoria da Fazenda Nacional" ${ }^{\text {76. }}$.

De toda forma, o tratamento diferenciado do prazo prescricional dos créditos do FGTS em função do autor da demanda para sua cobrança é ponto sensível que tem impacto negativo na recuperação dos créditos do Fundo.

Inicialmente pode-se apontar descrédito ao princípio da isonomia, pois a aplicação da prescrição trabalhista, quinquenal ou bienal prevista no inciso XXXIX do artigo $7^{\circ}$, da Constituição Federal, aplicada aos créditos do FGTS cobrados em ação trabalhista pelo próprio trabalhador, consoante o teor das Súmulas 206 e 362, do TST, evidencia injustificável desigualdade de tratamento à vista da cobrança dos créditos realizados pelo Poder Público com prazo prescricional trintenário.

O trabalhador como destinatário das verbas que devem ser recolhidas à sua conta vinculada do FGTS tem um tratamento mais restrito quanto ao prazo prescricional e se insere em condição de submissão de atuação estatal para cobrança de seus créditos do Fundo após o transcurso da prescrição quinquenal ou bienal, nas hipóteses dos citados enunciados de Súmula do TST.

Em crítica à Súmula 362, do TST, Francisco Antonio de Oliveira ${ }^{77}$ aponta que os depósitos do Fundo de Garantia, além de componente dos direitos dos trabalhadores, tem alcance muito maior, pois dá suporte ao financiamento de moradias populares. Além disso, o Governo Federal não tem possibilidades de exercer a fiscalização imposta pela Lei 8.036/90 e levantar os débitos inadimplidos de milhares de empresas que não depositam a contribuição do FGTS à espera da prescrição trabalhista, incentivando e premiando a inadimplência. E mais, cria uma situação inusitada, eis que o Poder Público tem poderes para exigir os créditos do Fundo no prazo de 30 (trinta) anos, ao passo que o trabalhador poderá ajuizar ação trabalhista em até 2 (dois) anos da extinção do contrato de trabalho.

Por fim, a apontada interpretação restritiva do lapso prescricional dos

\footnotetext{
${ }^{76}$ MARTINS, Sérgio Pinto. Manual do FGTS. Op. cit., p. 234.
} 
créditos do FGTS dada pelo Tribunal Superior do Trabalho, também afronta direcionamento dado ao tema pelo Superior Tribunal de Justiça, à vista da Lei 8.036/90, por meio da Súmula 210, sendo que a este sodalício, nos termos da Constituição Federal, compete exclusivamente decidir sobre o real alcance de lei federal (artigo 105, III, letras $a$, $b$ e $c$ da Constituição Federal de 1988).

A melhor solução para as divergências interpretativas encontra-se na unificação dos prazos para a prescrição do FGTS tanto na cobrança promovida pelos trabalhadores quanto pela União. Nesse sentido, visando à proteção do trabalhador deve prevalecer o lapso prescricional mais alargado.

Sem prejuízo de ter a Constituição da República, em seu artigo $7^{\circ}$, elencado o FGTS como direito do trabalhador, este não se encontra integralmente sujeito à prescrição estabelecida no inciso XXIX, do mesmo dispositivo, já que expressamente ressalvado o privilégio à prescrição trintenária pelo artigo $23, \S 5^{\circ}$, da Lei n. $8.036 / 90^{78}$.

A própria finalidade do FGTS de servir como indenização do tempo de serviço do trabalhador, atribui-lhe o sentido de um prazo prescricional diferenciado, que lhe garanta a compensação pelo tempo trabalhado. No ordenamento jurídico vigente, corrobora essa assertiva o artigo $201, \S 7^{\circ}$, da Constituição Federal e os dispositivos da Lei $8.213 / 91^{79}$, que determina um tempo de contribuição mínimo de trinta anos para se requerer aposentadoria voluntária, a qual é hipótese de levantamento dos valores depositados no Fundo de Garantia, segundo o artigo 20, III, da Lei 8.036/90. Diante da baixa incidência de ações trabalhistas durante a vigência do contrato de trabalho, a

\footnotetext{
${ }_{77}^{77}$ OLIVEIRA, Francisco Antônio de. Op. cit., p. 640/641.

${ }^{78}$ No STF pende julgamento do RE 522897, por meio do qual o relator Min. Gilmar F. Mendes defende a aplicação do prazo prescricional de cinco anos previsto no artigo $7^{\circ}$, da CF, declarando a inconstitucionalidade dos dispositivos legais que fixam o prazo de 30 anos para a prescrição dos créditos de FGTS, ou seja, do parágrafo $5^{\circ}$ do artigo 23 da Lei 8.036/90 e do artigo 55 do Decreto 99.684/90.

${ }^{79}$ Nos termos do artigo 201, $\S 7^{\circ}$ da Constituição Federal, e da correspondente Lei 8.213/91, no Regime Geral de Previdência Social, para ter direito à aposentadoria integral, o trabalhador homem deve comprovar pelo menos 35 anos de contribuição e a trabalhadora mulher, 30 anos. Para requerer a aposentadoria proporcional, o trabalhador tem que combinar dois requisitos: tempo de contribuição e idade mínima. Os homens podem requerer aposentadoria proporcional aos 53 anos de idade e 30 anos de contribuição, mais um adicional de 40\% sobre o tempo que faltava em 16 de dezembro de 1998 para completar 30 anos de contribuição. As mulheres têm direito à proporcional aos 48 anos de idade e 25 de contribuição, mais um adicional de $40 \%$ sobre o tempo que faltava em 16 de dezembro de 1998 para completar 25 anos de contribuição. Para ter direito à aposentadoria integral ou proporcional, é necessário também o cumprimento do período de carência, que corresponde ao número mínimo de contribuições mensais indispensáveis para que o segurado faça jus ao benefício. Os inscritos a partir de 25 de julho de 1991 devem ter, pelo menos, 180 contribuições mensais. Os filiados antes dessa data devem seguir uma tabela progressiva.
} 
prescrição quinquenal ou bienal acaba por prejudicar os trabalhadores com largo tempo de serviço ao mesmo empregador que eventualmente não recolheu ou recolheu a menor as contribuições ao Fundo.

E ainda, sob o manto do princípio protetor e tomado o FGTS como direito fundamental do trabalhador não há que se afastar a incidência da norma mais favorável representada pela prescrição trintenária prevista no artigo $23, \S 5^{\circ}$, da Lei $n$. 8.036/90, independentemente da prescrição das correlatas verbas trabalhistas que lhe dão suporte, seja o crédito perseguido pelo trabalhador ou pelo Estado, qualquer que seja o órgão do Poder Judiciário competente.

Por fim, de se reafirmar que o FGTS é um direito autônomo do trabalhador que decorre do contrato de trabalho, e não das verbas salariais que lhe servem de base de incidência, de modo que a prescrição dos valores correspondentes aos outros direitos trabalhistas que compõem a base de cálculo do FGTS não afasta sua exigibilidade.

Esse é um ponto fundamental e divisor de águas para afastar a interpretação da regra da prescrição trabalhista em face dos créditos do Fundo de Garantia do Tempo de Serviço, pois os Tribunais trabalhistas e a jurisprudência majoritária do Tribunal Superior do Trabalho fundamentam decisões sobre a prescrição quinquenal das contribuições devidas ao FGTS incidentes sobre a regra de que o acessório segue o principal. Confira-se o aresto abaixo:

A jurisprudência do c. TST firmou-se no sentido de que à pretensão de recolhimento de depósitos do FGTS não realizados aplica-se a prescrição trintenária, e ao pedido do FGTS como acessório em condenação de outras parcelas do contrato de trabalho não pagas, como acessório, aplica-se a prescrição qüinqüenal, eis que quando prescrito o principal também estará prescrito o acessório. ${ }^{80}$.

Fica evidente pela leitura da ementa supratranscrita que a jurisprudência é firme no sentido de que se aplica a prescrição qüinqüenal em relação a diferenças do FGTS decorrentes de parcelas do contrato de trabalho não adimplida, como acessória, eis que se prescrito o principal, também estará prescrito o acessório. Deste modo, observa-se a

\footnotetext{
${ }^{80}$ TST, 6a Turma, RR 3580000-39.2002.5.02.0902, Rel. Aloysio Corrêa da Veiga, DJ 07.04.2009.
} 
orientação sobre a prescrição qüinqüenal em relação ao pagamento do FGTS como parcela acessória, relegando a prescrição trintenária apenas à condenação ao pagamento do FGTS não depositado sobre remuneração inadimplida.

Com a necessária mudança interpretativa no sentido de se efetivar o FGTS como direito trabalhista autônomo a prescrição trabalhista, quinquenal e bienal, incidente sobre o pagamento de verbas trabalhistas reclamadas em ação judicial na Justiça do Trabalho, não terá o efeito jurídico de aniquilar os correspondentes recolhimentos dos valores devidos ao Fundo de Garantia do Tempo de Serviço, sujeitos à prescrição trintenária.

Nessa hipótese, para dar efetividade à cobrança das contribuições para o FGTS perseguida pelo trabalhador deve-se apurar e liquidar as verbas trabalhistas reclamadas mesmo que atingidas pela prescrição com o único fim de servir de base de cálculo para os valores devidos ao FGTS. 


\section{CAPÍTULO 3. A RECUPERAÇÃO ADMINISTRATIVA DOS CRÉDITOS DO FGTS PELA UNIÃO}

\subsection{Identificação dos interesses jurídicos}

O presente capítulo traz à lume uma análise minuciosa das questões e interesses envolvidos na dimensão administrativa da relação jurídica obrigacional que se estabelece entre o Estado e o empregador referente à inadimplência quanto aos recolhimentos dos valores de depósitos mensais e rescisórios referentes ao Fundo de Garantia, bem como de multas aplicadas pela fiscalização do trabalho com fundamento no artigo 23 da Lei 8.036/90.

O não recolhimento ou recolhimento a menor dos depósitos mensais e rescisórios devidos ao FGTS pelo empregador, são objetos de fiscalização administrativa procedida pelo Ministério do Trabalho e Emprego, culminando com a expedição de notificação ao devedor para recolhimento do valor em aberto apurado como devido, além da possibilidade de lavratura de auto de infração por descumprimento das regras do FGTS e aplicação de multa punitiva.

No capítulo será abordado o FGTS como objeto de ação fiscal no âmbito do Ministério do Trabalho e Emprego, o procedimento das notificações de débitos relacionados aos depósitos vinculados mensal e rescisório, que perpassa por considerações sobre a verificação do recolhimento, do levantamento de débitos, da notificação fiscal para recolhimento do Fundo de Garantia e da contribuição social, da notificação para recolhimento rescisório do FGTS e das contribuições sociais, e por fim, dos autos de infração relacionados às penalidades administrativas impostas pela fiscalização do trabalho e seus respectivos questionamentos judiciais. 
De se registrar que a fiscalização pela autoridade administrativa do trabalho quanto ao regular recolhimento dos créditos do FGTS pelo empregador apresenta uma faceta de resguardo dos direitos do trabalhador, na medida em que representa o poderdever do Estado em garantir o cumprimento da legislação trabalhista pelos empregadores, ao lado do resguardo do interesse econômico-social representado pela destinação legal dos recursos do FGTS para o financiamento dos programas do Sistema Financeiro da Habitação, de saneamento básico e infraestrutura urbana e de base.

Não há dúvidas de que a higidez financeira do FGTS deve ser orientada para albergar a sua dupla finalidade, pois à medida que não se realizam recolhimentos ao Fundo frustra-se a garantia creditória do trabalhador, além de acarretar prejuízo à sociedade pela redução das obras de infraestrutura urbana, saneamento básico e habitação popular, impossibilitando, inclusive, na mesma proporção, a abertura de novos postos de trabalho ligados a esses setores ${ }^{81}$.

As considerações e conclusões do presente capítulo tomam como paradigma a natureza jurídica do FGTS como direito fundamental do trabalhador, com tangenciamento da sua dupla finalidade legal, tanto sob o prisma do trabalhador, como crédito compensatório do seu tempo de serviço para ampará-lo diante de contingências legalmente previstas e servir como regime de indenização por sua dispensa arbitrária ou sem justa causa, como também sob o prisma do interesse público e social representado pelo financiamento de programas sociais de habitação, saneamento básico e infraestruturas urbana e de base.

\subsection{FGTS como objeto de ação fiscal no âmbito do Ministério do Trabalho e Emprego}

A Constituição Federal da República de 1988, em seu artigo 21, inciso XXIV, preceitua competir à União organizar, manter e executar a inspeção do trabalho.

${ }^{81}$ SÜSSEKIND, Arnaldo; MARANHÃO, Délio; VIANNA, Segadas; TEIXEIRA, Lima. Instituições de direito do trabalho. Op. cit., p. 681. 
Nesse sentido, estabelece o artigo 626, da Consolidação das Leis do Trabalho, incumbir às autoridades competentes do Ministério do Trabalho e Emprego, ou àquelas que exerçam funções delegadas, a fiscalização do fiel cumprimento das normas de proteção ao trabalho, sendo competentes para esse mister os auditores fiscais do trabalho.

O Ministério do Trabalho e Emprego, na sua estrutura atual ${ }^{82}$, conta com as seguintes unidades administrativas: Gabinete do Ministro, Secretaria-Executiva, Consultoria Jurídica, Ouvidoria-Geral, Secretaria de Políticas Públicas de Emprego, Secretaria de Inspeção do Trabalho-SIT, Secretaria de Relações do Trabalho, Secretaria Nacional de Economia Solidária, Superintendências Regionais do Trabalho e EmpregoSRTE, Gerências Regionais do Trabalho e Emprego-GRTE e Agências Regionais do Trabalho e Emprego. Compõem ainda a estrutura do Ministério do Trabalho e Emprego os seguintes órgãos colegiados: Conselho Nacional Curador do FGTS, Conselho Deliberativo do Fundo de Amparo ao Trabalhador, Conselho Nacional de Imigração, Conselho Nacional de Economia Solidária, Conselho Nacional do Trabalho, além da Fundacentro como órgão vinculado.

A fiscalização do trabalho visa a garantir o cumprimento da legislação de proteção ao trabalhador, com objetivo de combater a informalidade no mercado de trabalho e garantir observância da legislação trabalhista. A eficácia das leis trabalhistas, como as leis de proteção em geral, depende da fiscalização exercida quanto ao fiel cumprimento dos deveres impostos aos empregadores ${ }^{83}$.

O artigo 23, da Lei 8.036/90, combinado com o artigo $1^{\circ}$, da Lei 8.844/94, constituem as normas legais de base no que se refere à fiscalização e autuação quanto às infrações relacionadas aos não-recolhimentos mensais e rescisórios devidos pelos empregadores ao Fundo de Garantia do Tempo de Serviço, atribuindo a competência ao Ministério do Trabalho e Emprego o dever de fiscalização e apuração das contribuições de FGTS e, ainda, aplicação das multas e demais encargos devidos.

Nesse diapasão, o artigo 23, da Lei 8.036/90, traz a tipificação legal das infrações administrativas e as correspectivas penalidades cabíveis a serem verificadas e aplicadas pela fiscalização do trabalho quanto ao FGTS.

\footnotetext{
${ }^{82} \mathrm{O}$ Ministério do Trabalho e Emprego tem sua estrutura regimental regulamentada pelo Decreto $\mathrm{n}^{\mathrm{0}} 5.063$, de 03/05/2004, alterado pelo Decreto ${ }^{\circ}$ 6.341, de 03/01/2008 e pelo Decreto ${ }^{\circ} 7.015$, de 24/11/2009.
} 
De seu turno, o processo administrativo de fiscalização dos créditos do FGTS pelo Ministério do Trabalho e Emprego rege-se pelo disposto nos artigos 626 a 642, da CLT, consoante regra do $\S 5^{\circ}$ do artigo 23 , da Lei $8.036 / 90$, que determina que " $o$ processo de fiscalização, de autuação e de imposição de multas reger-se-á pelo disposto no Título VII da CLT, respeitado o privilégio do FGTS à prescrição trintenária".

Tanto o processo administrativo de fiscalização e apuração das contribuições mensais e rescisórias do FGTS, quanto o processo administrativo de fiscalização e aplicação de multas e demais encargos por descumprimento da legislação do Fundo de Garantia do Tempo de Serviço, estão submetidos às regras estipuladas no Título VII da Consolidação das Leis do Trabalho.

Não há razão para sustentar uma interpretação literal do $§ 5^{\circ}$, do artigo 23 da Lei 8.036/90, no sentido de que a lei deixou a autoridade do trabalho vinculada quanto ao procedimento de aplicação das multas e demais encargos devidos às normas do Título VII da CLT, ao passo que quanto ao dever de fiscalização e apuração das contribuições de FGTS há liberdade ao MTE para prever o procedimento nos estritos limites da lei. Essa interpretação literal levaria ao absurdo de se afirmar que somente as multas relativas ao FGTS, e não os créditos relativos aos recolhimentos mensais e rescisórios, estariam sujeitas ao prazo prescricional trintenário, mencionado no mesmo dispositivo legal considerado $^{84}$.

O $\S 5^{\circ}$, do artigo 23 , da Lei 8.036/90, deve ser entendido numa interpretação sistemática e finalística, como diretriz que determina a aplicação das normas do Título VII da CLT a ser seguida pelo MTE no seu mister de fiscalização e apuração das contribuições devidas ao Fundo de Garantia do Tempo de Serviço, bem assim a aplicação das multas e demais encargos devidos. Ora, as duas vertentes de fiscalização procedidas pela autoridade do trabalho recaem sobre créditos devidos ao FGTS e a aplicação de multas pressupõem condutas do empregador tipificadas pela lei, que coincidem com os fundamentos da fiscalização para fins de notificação dos valores do Fundo de Garantia.

\footnotetext{
${ }^{83}$ RUSSOMANO, Mozart Victor. Curso de Direito do Trabalho. Op. cit., p. 463.

${ }^{84}$ A interpretação literal do $\S 5^{\circ}$ do artigo 23 da Lei $8.036 / 90$ poderia apresentar algum efeito quanto à exigência de depósito prévio ao recurso administrativo exigido pelo $\S 1^{\circ}$ do artigo 636 da CLT, e que seria aplicável apenas aos autos de infração e imposição de multas, mas não ao recursos das notificações de recolhimento ao FGTS. Entretanto, a Súmula Vinculante do Supremo Tribunal Federal no 21, de 10.11.2009, espancou qualquer dúvida, ao estabelecer que "É inconstitucional a exigência de depósito ou arrolamento prévios de dinheiro ou bens para admissibilidade de recurso administrativo".
} 
A Portaria MTE 148/96 regulamentou os procedimentos específicos da fiscalização relativa ao FGTS e a Instrução Normativa da Secretaria de Inspeção do Trabalho do Ministério do Trabalho - IN SIT $n^{\circ}$ 84, de 13 de julho de 2010, trouxe obrigatoriedade quanto à verificação de regularidade dos recolhimentos do FGTS e das respectivas contribuições sociais (CS) instituídas pela Lei Complementar 110/01, em todas as ações fiscais, no meio urbano e rural, no setor público e privado.

De acordo com a norma administrativa citada o período a ser fiscalizado terá como início e término, respectivamente, a primeira competência não inspecionada e a última competência exigível, salvo se durante a ação fiscal for constatado indício de débito não notificado, ocasião em que deverá retroagir a fiscalização a outros períodos para fins de apuração dos respectivos valores.

É obrigatória a apresentação, quando solicitado pelo auditor fiscal do trabalho, de livros contábeis e fiscais, arquivos digitais, materiais, livros e assemelhados, além de outros documentos de suporte à escrituração das empresas, os quais estarão sujeitos a serem apreendidos mediante lavratura de termo para a verificação da existência de fraudes e irregularidades.

Constatado indícios de fraude o auditor informará à chefia imediata, por meio de relatório acompanhado dos documentos originais apreendidos, para comunicação aos órgãos públicos competentes. Previamente a esta comunicação os indícios de fraude apurados na própria guia de recolhimento do FGTS deverão ser encaminhadas à Caixa Econômica Federal - CEF para análise.

Sem prejuízo da fiscalização direta poderá ser adotado o procedimento de fiscalização indireta para a verificação dos recolhimentos do FGTS e das respectivas contribuições sociais. Se adotado o procedimento indireto o empregador será notificado, por meio de Notificação de Apresentação de Documentos - NAD, a comparecer à Superintendência Regional do Trabalho e Emprego - SRTE, ou em suas unidades descentralizadas, a fim de atender as solicitações determinadas.

Anote-se que a fiscalização do trabalho deverá observar o critério da dupla visita nas empresas devedoras, na forma do artigo 627, da Consolidação das Leis do Trabalho, o qual determina que para promover a instrução dos responsáveis no 
cumprimento das leis de proteção do trabalho a fiscalização deverá observar o critério de dupla visita em duas hipóteses. Uma, quando ocorrer promulgação ou expedição de novas leis, regulamentos ou instruções ministeriais, sendo que, com relação exclusivamente a esses atos, será feita apenas a instrução dos responsáveis. Outra, ao ser realizada a primeira inspeção dos estabelecimentos ou dos locais de trabalho recentemente inaugurados ou empreendidos.

A fiscalização pode ser realizada a qualquer tempo. De se esclarecer que não há previsão legal expressa de prazo decadencial em relação ao FGTS. A Lei n. ${ }^{\circ}$ 8.036/1990 somente prevê prazo de 30 anos para a prescrição. Em que pese o artigo 23, § $5^{\circ}$, da Lei ${ }^{\circ} 8.036 / 90$, referir-se apenas à prescrição cabe destacar que o prazo trintenário estabelecido pelo citado preceito abrange também a decadência. Significa dizer que o crédito pertinente ao Fundo de Garantia do Tempo de Serviço deverá ser constituído e cobrado judicialmente no prazo único de trinta anos.

Considerando que o FGTS não tem natureza tributária fica afastada a aplicação dos artigos 173 e 174 do Código Tributário Nacional, e portanto, não há um sistema de constituição por lançamento com prazos distintos. Assim, não há um prazo de 30 anos para a notificação de recolhimento e aplicação de multas administrativas e outros 30 anos para a sua cobrança judicial.

Apresenta-se como pressuposto para efetividade do modelo de recuperação administrativa dos créditos do FGTS pela União a legitimidade da fiscalização do trabalho para reconhecer a existência de relação de emprego, com o fim de embasar lavratura de auto de infração e aplicação de multa ao empregador faltoso com o cumprimento da legislação trabalhista.

Com efeito, nem sempre a relação de emprego é reconhecida pelo empregador, com a correspondente anotação da Carteira de Trabalho e Previdência Social e cumprimento das normas de proteção ao trabalho. Muitas vezes é necessário que o trabalhador ajuíze ação trabalhista para buscar o reconhecimento judicial da natureza do serviço prestado. Se por um lado há zonas de penumbra, nas quais a natureza do vínculo nem sempre transparece à primeira vista, há outros casos em que o próprio empregador, ciente de suas obrigações legais, prefere mascarar o liame afirmando falsamente se tratar de trabalho autônomo, estágio, ato cooperativo, dentre outras espécies de fraude. 
Evidentemente, o empregador que deixa de reconhecer o vínculo de trabalho subordinado tem como objetivo a majoração do lucro por meio da redução ilegal de custos, pois realizada mediante sonegação de verbas trabalhistas, previdenciárias e fiscais. Esta redução de custos ainda lhe permite uma concorrência desleal com outras empresas do mesmo ramo que cumpram com suas obrigações e precisam repassar os valores para seus preços ou arcarem com a redução da margem de lucro.

Nesse cenário fático é que se identifica a relevância da fiscalização administrativa do trabalho, exercida pelo Poder Executivo Federal, por intermédio do Ministério do Trabalho e Emprego para afastar as fraudes. Os auditores fiscais do trabalho têm por missão funcional a análise dos fatos apurados em diligências de fiscalização, o que não pode excluir o reconhecimento fático da relação de emprego, obviamente, garantindose ao empregador o acesso às instâncias administrativas ou judiciais, para fins de cancelamento da autuação ou multa imposta.

A fiscalização do trabalho não se arvora de competência atribuída ao Poder Judiciário, pois o auditor fiscal, diante da constatação fática sobre a ocorrência de contratos civis ou outras formas jurídicas com o objetivo de afastar ou impedir a aplicação da legislação trabalhista, inclusive a do FGTS, desconsidera o pacto nulo e reconhece a relação de emprego, mas não declara, com definitividade, a existência da relação, pois apenas constata e aponta a irregularidade administrativa, tendo como conseqüência a autuação e posterior multa à empresa infringente.

De se estabelecer que a justificativa máxima e filosófica do Direito do Trabalho é a dignidade humana e os direitos fundamentais dos trabalhadores enquanto seres humanos. Não é por outro motivo que a Declaração de Filadélfia, que faz parte integrante da Constituição da Organização Internacional do Trabalho - OIT, da qual o Brasil é membro fundador, estabelece expressamente que o trabalho não é mercadoria ${ }^{85}$.

Assim, não há como negar ao Poder Executivo Federal o seu poder-dever de inspeção e fiscalização das relações de trabalho, para garantia do cumprimento das normas protetivas do trabalho. Os Poderes da Federação não são estanques nesse papel,

\footnotetext{
${ }^{85}$ Declaração de Filadélfia - Declaração relativa aos fins e objetivos da Organização Internacional do Trabalho. Constituição. (...) A Conferência afirma novamente os principios fundamentais sobre os quais se funda a Organização, isto é: a) o trabalho não é uma mercadoria; (...). In Organização Internacional do
} 
pois antes compõem uma rede de proteção para a existência de uma sociedade livre, justa e solidária em conformidade com os mandamentos constitucionais que norteiam o Estado Democrático de Direito.

O artigo 628, da Consolidação das Leis do Trabalho, no capítulo intitulado 'Da Fiscalização, Da Autuação e Da Imposição de Multas', não deixa dúvidas sobre o papel da fiscalização do trabalho ao dispor que a toda verificação em que o auditor fiscal do trabalho concluir pela existência de violação de preceito legal deve corresponder, sob pena de responsabilidade administrativa, a lavratura de auto de infração. Soma-se a isto o disposto no artigo $9^{\circ}$, da CLT, como norma geral de Direito do Trabalho, estatuindo a nulidade de pleno direito dos atos praticados com o objetivo de desvirtuar, impedir ou fraudar a aplicação dos seus preceitos. A citada nulidade pleno jure é exatamente aquela que se opera de imediato, sem qualquer necessidade de pronunciamento prévio do Judiciário, que ao analisar eventual demanda proferirá decisão declaratória, nunca constituindo a partir daí a existência ou não de vínculo de emprego, eis que do contrário não se poderia cogitar de efeitos retroativos, inclusive com anotação da CTPS e determinação de recolhimentos previdenciários e para o FGTS.

Merece destaque o artigo $8 .^{\circ}$, da Consolidação das Leis do Trabalho, que combinado com o artigo 114, VII, da Constituição Federal, investe a inspeção do trabalho da prerrogativa de fiscalizar a regularidade das relações de trabalho constituídas.

Dessa forma, a fiscalização do trabalho tem atribuições legais para o reconhecimento da relação emprego, pois a ela cabe preventivamente assegurar a aplicação da legislação trabalhista sempre que se vislumbrar relações de trabalho. Nesse sentido Valentin Carrion leciona que os direitos do trabalhador são protegidos em dois níveis distintos, sendo que "a fiscalização do trabalho visa, administrativamente, o cumprimento da legislação laboral, paralelamente à atuação judiciária, que ao compor os litígios é como a mão comprida do legislador ${ }^{\prime \prime 6}$. O Tribunal Superior do Trabalho já manifestou esse entendimento, inclusive em caso específico do FGTS, conforme segue:

Trabalho. Constituição da Organização Internacional do Trabalho. trad. Margarida Robert. Lisboa : MQE. CICT, 1996, p. 99.

${ }^{86}$ CARRION, Valentin. Comentários à Consolidação das Leis do Trabalho. 32. ed. São Paulo: Saraiva, 2007, p. 484. 
Não invade a esfera da competência da Justiça do Trabalho a declaração de existência de vínculo de emprego feita pelo físcal do trabalho, por ser sua atribuição verificar o cumprimento das normas trabalhistas, tendo essa declaração eficácia somente quanto ao empregador, não transcendendo os seus efeitos subjetivos para aproveitar, sob o ponto de vista processual, ao trabalhador. Assim, verificado pelo fiscal de trabalho que há relação de emprego entre a empresa tomadora de serviço e o trabalhador, não há óbice na cobrança do FGTS pela União, em razão de tal atribuição estar prevista no artigo 23 da Lei 8.036/90. Portanto, o que é devido pela empresa a título de FGTS não é de interesse exclusivo do empregado, mas também da União. Afastada a invasão da competência da Justiça do Trabalho, devem os autos retornar à origem para análise dos demais fundamentos e pedidos da petição inicial. Recurso de revista conhecido e provido $^{87}$.

Assim, apresenta-se inegável e pressuposto para a efetividade das notificações e autuações referentes ao FGTS a competência do Ministério do Trabalho e Emprego para executar os atos e procedimentos atinentes à fiscalização, autuação e imposição da multa correlata, a teor das disposições contidas, em especial, nos artigos 626 e 628, da Consolidação das Leis do Trabalho, de tal maneira que constatada a irregularidade é dever do auditor fiscal do trabalho lavrar o correspondente auto de infração, sob pena de responsabilidade, sendo direito do administrado recorrer administrativamente da multa, bem como ajuizar ação anulatória caso entenda indevida a autuação.

\subsection{Notificações de débitos relacionados aos depósitos vinculados mensais e rescisórios}

\subsubsection{Verificação do recolhimento e levantamento de débitos do}

\section{FGTS}

A Lei . $^{\circ} 8.844 / 94$, em seu artigo $1^{\circ}$, atribuiu ao Ministério do Trabalho a competência para a prática dos atos de fiscalização e a apuração das contribuições devidas ao Fundo de Garantia do Tempo de Serviço, bem assim a aplicação das multas e demais

\footnotetext{
${ }^{87}$ TST, 6 a Turma, RR-131140-48.2005.5.03.0011, Rel. Augusto César Leite de Carvalho, DJ 10.12.2010.
} 
encargos devidos. Assim, cabe ao Ministério do Trabalho e Emprego ${ }^{88}$ a atribuição de apurar o valor devido ao FGTS e a notificação e aplicação de multas aos empregadores e tomadores de serviço infratores da legislação do Fundo.

Destaque-se que o processo de fiscalização, de autuação e de imposição de multas do FGTS, inclusive o procedimento de verificação e levantamento de débitos e notificação de recolhimento regem-se pelo disposto no Título VII da Consolidação das Leis do Trabalho, composto pelos seus artigos 626 a 642, consoante estabelece o $\S 5^{\circ}$, do artigo 23, da Lei 8.036/90.

O processo administrativo de fiscalização referente ao FGTS segue as diretivas específicas ditadas pela Portaria MTE 148/96, complementado pela vigente Instrução Normativa da Secretaria de Inspeção do Trabalho do Ministério do Trabalho e Emprego - IN SIT no 84, de 13 de julho de 2010, que, na esteira das suas precedentes (Instruções Normativas da SIT $n^{\text {o }}$ 03/1996, 17/2000 e 25/2001), determinou a obrigatoriedade, em todas as ações fiscais, da verificação de regularidade dos recolhimentos do FGTS e das respectivas contribuições sociais (CS) instituídas pela Lei Complementar 110/01, no meio urbano e rural, no setor público e privado.

A partir do não recolhimento dos recursos devidos ao FGTS pelo empregador, verificado pela fiscalização do Ministério do Trabalho e Emprego, há a expedição de uma notificação ao devedor pelo auditor fiscal do trabalho para recolhimento do valor em aberto apurado como devido.

As normas administrativas reguladoras do processo de fiscalização dos recolhimentos para o FGTS estabelecem duas espécies de notificações fiscais para os créditos do Fundo de Garantia. Tratam-se da Notificação Fiscal para Recolhimento do Fundo de Garantia e da Contribuição Social - NFGC, e da Notificação Fiscal para Recolhimento Rescisório do FGTS e das Contribuições - NRFC, previstas, respectivamente nos artigos 35 e 37 da IN MTE/SIT no 84, de 13 de julho de $2010^{89}$.

${ }^{88}$ O Ministério do Trabalho passou a ser denominado Ministério do Trabalho e Emprego, por força da Medida Provisória ${ }^{\circ} 1.799$, de $1^{\text {o }}$ de janeiro de 1999.

${ }^{89}$ A norma geral regulamentadora da fiscalização do trabalho quanto aos recolhimentos do FGTS é a Portaria MTE $n^{\circ}$ 148/96, complementada pelas instruções normativas específicas da Secretaria de Inspeção do Trabalho - SIT. A norma determina, mediante constatação de ausência do depósito devido ao FGTS, ou se efetuado a menor, a expedição contra o infrator a Notificação para Depósito do Fundo de Garantia - NDFG, sem prejuízo da lavratura dos autos de infração que couberem. A NDFG foi prevista nas Instruções 
$\mathrm{Na}$ hipótese de ser apurado débito, seja por falta de recolhimento ou recolhimento a menor relativamente às contribuições mensais referentes ao FGTS, o auditor fiscal do trabalho emitirá a Notificação Fiscal para Recolhimento do Fundo de Garantia e da Contribuição Social - NFGC, a fim de que o empregador recolha a importância apurada como devida, sendo que a individualização do débito é responsabilidade do empregador.

Por sua vez, sendo apurado débito por falta de recolhimento ou recolhimento a menor com relação à remuneração paga no mês da rescisão, no mês anterior, no $13^{\circ}$ salário proporcional e no $13^{\circ}$ e aviso prévio indenizados, ou quanto à indenização rescisória, conforme Lei $\mathrm{n}^{0}$ 9.491/97, o auditor fiscal do trabalho emitirá a Notificação Fiscal para Recolhimento Rescisório do FGTS e das Contribuições - NRFC, a fim de que o empregador recolha a importância devida.

A Notificação Fiscal para Recolhimento do Fundo de Garantia e da Contribuição Social - NFGC é constituída pelos seguintes documentos elaborados pelo auditor fiscal do trabalho: o demonstrativo do débito, contendo, por competência, a base de cálculo, os valores devidos, recolhidos e o débito apurado do FGTS e contribuição social mensal; a relação dos recolhimentos considerados; a relação dos estabelecimentos e dos tomadores de serviço; a relação dos empregados a que o débito se refere, por competência, com indicação do nome, data de admissão, débito do FGTS de cada empregado e, quando houver, data de afastamento e número do PIS; e o relatório circunstanciado, contendo a indicação do período auditado e todas as competências verificadas, o tipo de auditoria (normal ou auditoria de confissão de débito), a indicação de débito original ou débito complementar aos valores anteriormente notificados, a indicação da forma do levantamento de débito, a relação dos documentos examinados e das fontes de consulta a sistemas informatizados, as ocorrências especiais na apuração do débito, como recomposição da folha de pagamento e arbitramento com descrição dos critérios utilizados, a relação de guias de recolhimento não consideradas no levantamento do débito, com indicação do motivo, a identificação dos co-responsáveis existentes na data da emissão da NFGC, com qualificação completa, incluindo os demais responsáveis do período abrangido

Normativas da SIT no 03/1996 e 17/2000, e a partir da instituição das contribuições sociais mensais e rescisória pela Lei Complementar $\mathrm{n}^{\circ} 110 / 01$, as instruções normativas posteriores, IN SIT $n^{\circ} 25 / 2001$, e atual IN SIT $n^{\circ}$ 84/2010, passaram a discriminar as notificações do FGTS quanto aos recolhimentos mensais e rescisórios separadamente, por meio das NFGC e NRFC, respectivamente. 
pela notificação, e a indicação dos autos de infração correlatos com o débito notificado, incluindo os lavrados por afronta ao artigo 630, da CLT, com a informação da capitulação e da ementa respectiva.

De seu turno, a Notificação Fiscal para Recolhimento Rescisório do FGTS e das Contribuições - NRFC deve ser constituída pelo auditor fiscal do trabalho mediante os seguintes documentos integrativos: demonstrativo do débito individualizado por empregado, contendo os valores devidos, recolhidos e o débito apurado do FGTS e CS mensal e rescisória; a recomposição do saldo da conta vinculada, quando houver competências não recolhidas ou recolhidas a menor, ou quando o saldo for calculado a partir das remunerações do período laboral do trabalhador; a relação de recolhimentos parciais relativos às competências recolhidas a menor; a relação dos recolhimentos rescisórios considerados por empregado; a relação de guias de recolhimento não consideradas no levantamento do débito, com indicação do motivo; e o relatório circunstanciado contendo todas as informações que propiciem a reconstituição do débito a qualquer tempo, inclusive demonstrativo especificando a recomposição ou o arbitramento efetuado, devidamente individualizado por empregado.

Pelo exposto, verifica-se que as notificações de recolhimento rescisório identificam os valores originários devidos aos trabalhadores que tiveram seus contratos rescindidos, e contam com um quadro de individualização, do qual deve constar o nome do empregado, número do PIS, data de admissão e afastamento, especificação do tipo de aviso prévio e das alíquotas, as verbas indenizatórias da rescisão, a remuneração devida no mês anterior e no mês da rescisão, com seu respectivo subtotal e o saldo para fins rescisórios. Registre-se que caso a empresa fiscalizada não apresente a individualização dos trabalhadores envolvidos no débito de FGTS notificado, na hipótese em que a fiscalização não possua os elementos para tanto, deve ser realizada a autuação e aplicação de multa, com base no inciso II do $\S 1^{\circ}$, do artigo 23, c/c o artigo 15, caput, da Lei $n^{\circ} 8.036 / 90$.

Após emitidas as notificações fiscais para recolhimento dos valores devidos ao Fundo de Garantia do Tempo de Serviço, seja NFGC ou NRFC, abre-se a possibilidade de procedimento de retificação ou alteração do débito notificado.

O termo de retificação será emitido pelo auditor fiscal notificante para inclusão, exclusão ou alteração de dados ou valores na notificação de débito. O termo de 
retificação será lavrado para correção da notificação fiscal emitida que vise a alterar a identificação ou qualificação dos co-responsáveis e estabelecimentos tomadores de serviço ou filiais, de informação sobre isenção ou desobrigação do recolhimento das contribuições sociais, ou alteração de dados ou valores de competências notificadas, recolhimentos informados ou empregados relacionados. O débito retificado deve ser atualizado até a data da emissão da notificação que lhe deu origem, sendo vedada a dedução de depósitos do FGTS ou respectiva contribuição social quando efetuados após essa data, bem como a inclusão de competências fora do período auditado, devendo ser reaberto o prazo legal para defesa do notificado.

O Termo de Alteração do Débito - TAD será emitido pelo auditor fiscal do trabalho para correção de valores lançados na notificação de débito. O TAD não será emitido se depender de diligência, ou se os elementos constantes dos autos forem insuficientes para a alteração, bem como se restarem comprovados equívocos que não envolvam valores. A emissão do TAD não renovará o prazo para defesa nem poderá majorar o débito total notificado, ficando vedada a inserção de novas competências ou trabalhadores envolvidos com o débito notificado.

Cumpre traçar as linhas básicas nas quais se desenvolve a fiscalização do trabalho para verificação e apuração dos valores devidos ao FGTS, e que fundamentam a emissão das correspondentes notificações de recolhimento (NFGC e NRFC).

No procedimento de verificação dos valores devidos mensalmente ao FGTS o auditor fiscal do trabalho deverá identificar o recolhimento do FGTS e da respectiva contribuição social, incidentes sobre a remuneração paga ou devida aos trabalhadores, nos percentuais estabelecidos em lei, respectivamente, oito por cento, e cinco décimos por cento (artigo $2^{\circ}$ da Lei Complementar n. $\left.{ }^{\circ} 110 / 2001\right)$. Na verificação do recolhimento do FGTS nos contratos de aprendizagem previstos na Lei n. ${ }^{\circ}$ 10.097/00, o percentual é de $2 \%$ (dois por cento); e, nos contratos por prazo determinado instituídos pela Lei n. ${ }^{\circ}$ 9.601/98, no período de fevereiro de 1998 a janeiro de 2003, o percentual é de $2 \%$ (dois por cento) a $8 \%$ (oito por cento). Deve ser observado ainda, que é devido o depósito do FGTS na conta vinculada do trabalhador cujo contrato de trabalho com a Administração Pública seja declarado nulo por ausência de concurso público, nos termos do artigo 37, § $2^{\circ}$, da Constituição Federal, desde que reconhecido o direito à percepção salarial. 
De outro turno, no procedimento de verificação dos valores devidos ao FGTS por dispensa sem justa causa, rescisão indireta do contrato de trabalho e rescisão antecipada de contrato a termo por iniciativa do empregador, inclusive do contrato de trabalho temporário, o auditor fiscal do trabalho deve identificar o recolhimento do FGTS e da correlata contribuição social incidentes sobre o montante de todos os depósitos devidos ao FGTS na vigência do contrato de trabalho, atualizados monetariamente e acrescidos dos respectivos juros remuneratórios, não se deduzindo, para este fim, os saques ocorridos. Aqui, em regra geral, o percentual devido relativo ao FGTS é de 40\% (quarenta por cento), e a contribuição social prevista no artigo $1^{\mathrm{o}}$ da Lei Complementar n. ${ }^{\circ} 110 / 01$, é calculada no percentual de 10\% (dez por cento). O percentual do FGTS será de 20\% (vinte por cento) na ocorrência de dispensa por culpa recíproca ou força maior, reconhecidas pela Justiça do Trabalho. De se registrar que, nos contratos a termo celebrados de acordo com a Lei n. ${ }^{\circ}$ 9.601/1998, exceto se convencionado pelas partes, não se aplica a multa rescisória, e ainda, os empregadores domésticos estão isentos da contribuição social rescisória por dispensa sem justa causa, nos termos da LC 110/01.

Constatando quaisquer irregularidades quanto ao recolhimento dos valores correspondentes ao FGTS e respectiva contribuição social o auditor físcal do trabalho procederá ao levantamento do débito, individualizado por empregado, e emitirá a notificação respectiva para que o empregador recolha a importância devida.

$\mathrm{Na}$ hipótese da existência de documentação que, embora incompleta, propicie a identificação de empregados em situação irregular, ou que se apure a existência de trabalho informal ou simulação contratual, a fiscalização do trabalho deve proceder ao levantamento por recomposição de folha de pagamento, utilizando-se dados declarados em sistemas informatizados. Trata-se de um procedimento especial disciplinado pela IN SIT $n^{\circ}$ 84/2010, que estabelece também o levantamento do débito por arbitramento se não for possível a recomposição da folha de pagamento, devendo ser observado o parâmetro mais favorável ao empregado, dentre eles: a remuneração paga ao empregado em meses anteriores ou posteriores; a remuneração para a outros empregados da mesma empresa que exerçam ou exerciam função equivalente ou semelhante; o piso salarial da categoria profissional; o salário profissional; o piso salarial previsto na Lei Complementar n. ${ }^{\circ}$ 103/00; e o salário mínimo nacional. 
Repise-se que a fiscalização do trabalho tem atribuições legais para o reconhecimento da relação emprego, pois a ela cabe preventivamente assegurar a aplicação da legislação trabalhista sempre que se vislumbrar relações de trabalho. Nesse sentido, e com base nos princípios protetor e da norma mais favorável, apresenta-se legítimo o procedimento especial de apuração dos créditos do FGTS pela fiscalização do trabalho estabelecido pela citada instrução normativa da Secretaria de Inspeção do Trabalho do Ministério do Trabalho e Emprego.

Anote-se por oportuno que nas ações fiscais em que se verificar a existência de confissão de débito junto à Caixa Econômica Federal, geralmente para fins de parcelamento, em data anterior ao início da ação fiscal, a fiscalização deverá emitir Demonstrativo de Auditoria de Débito Confessado-DAC, para fins de informação ao agente operador do FGTS. A confissão de dívida ou acordo de parcelamento firmado junto à Caixa Econômica Federal, depois de iniciada a fiscalização, não dispensa a obrigatoriedade da apuração do débito.

\subsubsection{Individualização dos trabalhadores titulares dos créditos do}

\section{FGTS}

A norma interna de fiscalização do MTE (IN SIT nº 84/2010) determina que a individualização do valor devido ou recolhido de FGTS na conta vinculada do empregado é obrigação do empregador.

Essa determinação está de acordo com o entendimento do extinto Tribunal Federal de Recursos, expresso na sua Súmula $n^{\circ} 181$, segundo a qual, em interpretação dos então vigentes artigos $2^{\circ}$, parágrafo único, 19 e 20, da Lei 5.107/66, “cabe ao empregador, e não ao BNH ou IAPAS, o encargo de individualizar as contas vinculadas dos empregados, referentes ao FGTS”. O Superior Tribunal de Justiça aplica o 
enunciado de súmula citado afirmando que a individuação dos empregados é dever do empregador ${ }^{90}$.

As regras da Lei 8.036/90, especialmente as contidas nos seus artigos 15, 17 e 23, determinam a obrigação do empregador de realizar os depósitos da importância correspondente aos recolhimentos mensais do FGTS até o dia 7 (sete) de cada mês, em conta bancária vinculada, bem como a obrigação dos empregadores de comunicar mensalmente aos trabalhadores sobre os valores recolhidos ao FGTS, com repasse de todas as informações sobre suas contas vinculadas recebidas da Caixa Econômica Federal, constituindo infração administrativa a omissão das informações sobre a conta vinculada do trabalhador.

Nesse sentido extrai-se que a obrigação de individualização dos trabalhadores beneficiários dos recolhimentos do FGTS é do empregador, conforme Súmula 181 do extinto TFR. Essa interpretação chancela que a ausência da individualização pelo auditor fiscal do trabalho não gera o efeito de nulidade das notificações para recolhimento dos valores devidos ao FGTS pelo empregador fiscalizado.

Em que pese a individualização dos trabalhadores ser responsabilidade imputada aos empregadores constitui providência que não deve ser olvidada pela fiscalização do trabalho, pois embasa a emissão da Notificação Fiscal para Recolhimento do Fundo de Garantia e da Contribuição Social - NFGC, e da Notificação Fiscal para Recolhimento Rescisório do FGTS e das Contribuições - NRFC, previstas respectivamente nos artigos 35 e 37 da IN MTE/SIT no 84/10. Assim, apresenta-se como tarefa inerente à fiscalização do trabalho a verificação sobre a individualização dos trabalhadores beneficiários dos créditos do Fundo de Garantia.

E ainda, se o auditor fiscal do trabalho constatar a existência de depósito de FGTS não individualizado na conta vinculada do trabalhador deverá notificar o empregador para regularização junto à Caixa Econômica Federal, e, se for o caso, autuar com base no artigo 23 , inciso II do $\S 1^{\circ}$, c/c o artigo 15 , caput, da Lei n. ${ }^{\circ} 8.036 / 1990$.

\footnotetext{
${ }^{90}$ STJ, $1{ }^{\text {a }}$ Turma, Ag. 0019390-55-2010.4.04.0000, Rel. Benedito Gonçalves, DJ 02.12.2010.
} 
A providência de individualização dos créditos na fase administrativa de recuperação dos créditos do FGTS é de extrema relevância para garantia de destinação dos valores cobrados pelo Poder Público Federal à conta vinculada do trabalhador.

Na prática, a não individualização dos créditos do FGTS constituídos por meio das notificações de recolhimento emitidas (NFGC e NRFC) impossibilita a devida destinação dos valores cobrados às contas vinculadas dos trabalhadores, levado à satisfação apenas do interesse arrecadatório fiscal, em prejuízo aos trabalhadores titulares dos créditos.

Assim, devem se tomadas como paradigmas pela fiscalização do trabalho as finalidades trabalhista e econômico-social do Fundo de Garantia do Tempo de Serviço, e não apenas o interesse em subsidiar políticas econômico-sociais do sistema financeiro da habitação, saneamento básico, infraestrutura urbana e infraestrutura de base.

\subsection{Autuações quanto às infrações e penalidades administrativas do Fundo de Garantia}

Constatado que o depósito devido ao FGTS não foi efetuado, ou foi efetuado a menor, deverá ocorrer a expedição contra o infrator das correspondentes notificações fiscais de recolhimento dos débitos (NFGC e NRFC), sem prejuízo da lavratura dos autos de infração que couberem, pois existem condutas tipificadas na lei que constituem infração administrativa à legislação do FGTS, e são objeto de aplicação de penalidade pela fiscalização do trabalho, a par das notificações de recolhimento.

O artigo 628, da Consolidação das Leis do Trabalho, estabelece expressamente que "a toda verificação em que o agente da inspeção concluir pela existência de violação de preceito legal deve corresponder, sob pena de responsabilidade administrativa, a lavratura de auto de infração”. 
O artigo 23, da Lei 8.036/90, constitui-se na norma legal que fundamenta a fiscalização e autuação quanto às infrações da legislação do Fundo de Garantia do Tempo de Serviço pelos empregadores, estabelecendo a tipificação legal das infrações administrativas e as penalidades cabíveis a serem verificadas e aplicadas pela fiscalização do trabalho quanto ao FGTS.

Nos termos do $\S 1^{\circ}$, do artigo 23, da Lei 8.036/90, constituem infrações à legislação do FGTS: não depositar o percentual relativo ao FGTS referente aos recolhimentos mensais e rescisório, nos prazos legais; omitir as informações sobre a conta vinculada do trabalhador; apresentar com erros ou omissões as informações dos trabalhadores beneficiários ao Cadastro Nacional do Trabalhador ${ }^{91}$; deixar de computar, para efeito de cálculo dos depósitos do FGTS, parcela componente da remuneração; e, deixar de efetuar os depósitos e os acréscimos legais, após notificado pela fiscalização.

O $\S 2^{\circ}$, do artigo 23 , da Lei $8.036 / 90$ cuida de estabelecer as penalidades de multa pelas infrações administrativas tipificadas no seu $\S 1^{\circ}$.

Assim, por omitir as informações sobre a conta vinculada do trabalhador ou por apresentar com erros ou omissões as informações dos trabalhadores beneficiários ao Cadastro Nacional do Trabalhador está o empregador sujeito à multa de 2 (dois) a 5 (cinco) $\mathrm{BTN}^{92}$ (artigo 23, §2 “a” da Lei 8.036/90).

E, pelas condutas omissivas de não depositar o percentual relativo ao FGTS referente aos recolhimentos mensais e rescisório nos prazos legais, bem como de deixar de computar, para efeito de cálculo dos depósitos do FGTS, parcela componente da remuneração, e também por deixar de efetuar os depósitos e os acréscimos legais, após notificado pela fiscalização, o empregador está sujeito à multa de 10 (dez) a 100 (cem)

\footnotetext{
${ }^{91}$ A referência ao Cadastro Nacional de Trabalhadores deve ser interpretada à luz da sistemática vigente do FGTS, entendendo-se caracterizada a infração na hipótese do empregador deixar de prestar informações necessárias sobre os trabalhadores sujeitos ao FGTS, como por exemplo, preencher incorretamente ou deixar de incluir trabalhador na GFIP (Guia de Recolhimento do Fundo de Garantia por Tempo de Serviço e Informações à Previdência Social com obrigatoriedade de apresentação instituída pela Lei $\mathrm{n}^{\circ}$ 9.528/97), por meio do Sistema Empresa de Recolhimento do FGTS e Informações à Previdência Social (SEFIP). In JANTAIA, Fabiano. FGTS - Fundo de Garantia do Tempo de Serviço. Op. cit., p. 143.

${ }^{92}$ Com a extinção do BTN, índice sucessor da ORTN e OTN, e a criação da taxa referencial - TR pela Lei n. ${ }^{\circ}$ $8.177 / 91$, o BTN deve ser atualizado até $1 .^{\circ}$ de fevereiro de 1991, e depois corrigido pela TR mensalmente. Segundo a jurisprudência do STJ, com a extinção da ORTN, o valor correspondente atualizado deve ser encontrado a partir da interpretação da norma que extinguiu um índice e o substituiu por outro, mantendo-se a paridade das unidades de referência, sem efetuar a conversão para moeda corrente, para evitar a perda do valor aquisitivo. (STJ, REsp. $\mathrm{n}^{\circ}$ 607.930/DF, Rel. Min. Eliana Calmon).
} 
BTN (artigo 23, §2 “b” da Lei 8.036/90). De se recordar que, não ocorrendo a individualização dos créditos pelo empregador fiscalizado será lavrado auto de infração e aplicada a penalidade ora retratada, podendo o empregador discutir administrativamente o auto de infração e as subjacentes notificações fiscais perante o órgão local do Ministério do Trabalho e Emprego.

Nas hipóteses em que o auditor fiscal do trabalho verificar fraude, simulação, artifício, ardil, resistência, embaraço ou desacato à fiscalização, assim como na reincidência, as multas serão duplicadas, sem prejuízo das demais cominações legais.

E ainda, os valores das multas não recolhidas no prazo legal serão atualizados monetariamente até a data de seu efetivo pagamento.

No caso das multas variáveis, ou seja, aquelas em que a lei indica apenas o valor mínimo e o valor máximo, como no caso das multas do FGTS previstas no $\S 2^{\circ}$ do artigo 23 da Lei 8.036/90, a gradação da multa se dá com base em parâmetros previstos em portaria do Ministro do Trabalho e Emprego, de forma a garantir a isonomia entre os empregadores na mesma situação que devem ser punidos com multas de mesmo valor.

Importa ressaltar que as multas de que ora se cuidam são de natureza punitiva e não de natureza moratória. Os encargos da mora decorrem do mero inadimplemento das obrigações de recolhimento ao FGTS. Nesse diapasão, o artigo 22, da Lei 8.036/90, determina que o empregador que não realizar os depósitos do FGTS no prazo legal, responderá pela incidência da Taxa Referencial - TR, cobrada por dia de atraso, sobre a importância correspondente, tomando-se por base o índice de atualização das contas vinculadas do FGTS. Sobre o valor dos depósitos acrescido da TR incidirão juros de mora de $0,5 \%$ ao mês ou fração, e multa moratória, em percentual progressivo de $5 \%$ no mês de vencimento da obrigação e $10 \%$ a partir do mês seguinte ao do vencimento da obrigação, sujeitando-se também às obrigações e sanções previstas no Decreto-Lei $n^{\circ} 368$, de 19 de dezembro de $1968^{93}$.

${ }^{93}$ O Decreto-Lei no 368/68 dispõe sobre efeitos de débitos salariais, proibindo a empresa em débito salarial com seus empregados de: pagar honorário, gratificação, pro labore ou qualquer outro tipo de retribuição ou retirada a seus diretores, sócios, gerentes ou titulares de firma individual; distribuir quaisquer lucros, bonificações, dividendos ou interesses a seus, sócios, titulares, acionistas, ou membros de órgãos, dirigentes, fiscais ou consultivos; e de ser dissolvida. E para a empresa em mora contumaz (em atraso ou sonegação de salário devidos aos empregados, por período igual ou superior a três meses, sem motivo grave e relevante, 
As infrações às obrigações relativas ao recolhimento do FGTS e das correlatas contribuições sociais instituídas pela Lei Complementar 110/01 ensejam a lavratura de autos de infração distintos, consoante determina a IN SIT n ${ }^{\text {o 84/2010. Tal }}$ providência de segregação das autuações quanto ao conteúdo ocorrem por serem distintos os regimes jurídicos aplicáveis em cada situação considerada, pois as infrações relativas aos recolhimentos mensais e rescisórios do Fundo de Garantia do Tempo de Serviço têm natureza administrativa, ao passo que as infrações relacionadas às obrigações relativas às contribuições sociais instituídas pela Lei Complementar 110/01 submetem-se ao regime jurídico tributário.

\subsection{Defesa do empregador em face das notificações de recolhimento e auto de infração relativos ao FGTS}

O procedimento administrativo de fiscalização, de autuação e de imposição de multas do FGTS rege-se pelo disposto no Título VII da Consolidação das Leis do Trabalho, composto pelos seus artigos 626 a 642, consoante estabelece o $\S 5^{\circ}$ do artigo 23, da Lei 8.036/90.

Assim, seguindo as diretrizes do artigo 629 da Consolidação das Leis do Trabalho, uma via das notificações de recolhimento (NFGC e NRFC), bem como do auto de infração deve ser entregue ao empregador fiscalizado, contra recibo, ou a ele enviada em registro postal, com franquia e recibo de volta, dentro de 10 (dez) dias da respectiva lavratura, sob pena de responsabilidade.

excluídas as causas pertinentes ao risco do empreendimento), proíbe-se o favorecimento com qualquer benefício de natureza fiscal, tributária, ou financeira, por parte de órgãos da União, dos Estados ou dos Municípios ou de que estes participem. 
Recebida a notificação e o auto de infração o empregador poderá efetuar o pagamento dos débitos notificados ou apresentar defesa em face da notificação e do auto de infração lavrado.

Quanto à quitação de débitos notificados a norma regulamentar do MTE determina que se houver quitação operada a partir da data da emissão da notificação, inclusive, esta será considerada pela Caixa Econômica Federal, cabendo ao MTE apreciar a quitação ocorrida em data anterior à emissão da notificação.

Os recolhimentos realizados em data posterior à emissão da notificação que quitem integralmente o débito notificado, ou concessão de seu parcelamento, confirmam a procedência do débito e operam o encerramento da esfera administrativa.

Quanto à apresentação de defesa na via administrativa, o empregador notificado ou autuado terá para apresentá-la o prazo de 10 (dez) dias contados do recebimento da notificação ou do auto de infração, consoante disposto no $\S 3^{\circ}$, do artigo 629, da CLT.

O empregador deverá dirigir a sua defesa ao Superintendente Regional do Trabalho ou a autoridade a quem ele tenha delegado competência para a prática do ato, a exemplo dos Gerentes Regionais do Trabalho.

A IN SIT $n^{\circ} 84 / 2010$ estabelece que os documentos apresentados em fase de defesa ou recurso serão apreciados pela autoridade competente apenas no momento da decisão, independente do número de vezes que o notificado se manifestar no processo.

Da decisão administrativa de primeira instância cabe recurso, em dez dias, nos termos do artigo 636, da CLT. O recurso é dirigido à Secretaria de Fiscalização do Trabalho ou Secretaria de Segurança e Saúde no Trabalho, como órgãos de segunda instância administrativa na atual estrutura do Ministério do Trabalho e Emprego.

O $\S 1^{\circ}$, do artigo 636, da CLT, exigia depósito recursal da multa. Registre-se que a Súmula Vinculante do Supremo Tribunal Federal no 21, de 10.11.2009, determinou que "é inconstitucional a exigência de depósito ou arrolamento prévios de dinheiro ou bens para admissibilidade de recurso administrativo". 
Encerrada a tramitação administrativa no âmbito do MTE e mantidas as notificações e o auto de infração o processo será remetido para cobrança do débito podendo ser reapreciado apenas em caso de nulidade, erro material ou apresentação de provas de quitação operada em data anterior à da emissão da notificação de débito.

O devedor deverá ser comunicado pelo setor de multas e recursos da existência do débito passível de inscrição em dívida ativa e conseqüente inclusão do notificado no Cadastro Informativo de Créditos Não Quitados do Setor Público Federal CADIN.

Confirmadas as notificações fiscais emitidas pela fiscalização do trabalho e eventuais multas aplicadas, os correspondentes créditos do FGTS serão levados à inscrição em dívida ativa da União e instaurada a cobrança judicial pela ProcuradoriaGeral da Fazenda Nacional ou pela Caixa Econômica Federal, mediante convênio.

Ao empregador notificado ou autuado pela fiscalização do trabalho quanto aos créditos do FGTS, que tenha contra si coisa julgada administrativa desfavorável, poderá ainda se valer da via judicial para buscar a anulação das notificações e do auto de infração, uma vez que, nos termo do inciso XXXV, do artigo $5^{\circ}$, da Constituição Federal, "a lei não excluirá da apreciação do Poder Judiciário lesão ou ameaça a direito".

A ação anulatória de um auto de infração referente ao FGTS lavrado pela autoridade administrativa do trabalho, nos termos do artigo 23, da Lei 8.036/90, deve ser processada na Justiça do Trabalho, com fundamento no artigo 114, VII da Constituição Federal, fruto da Emenda Constitucional n. ${ }^{\circ}$ 45/2004, que determina ser competência da Justiça do Trabalho processar e julgar as ações relativas às penalidades administrativas impostas aos empregadores pelos órgãos de fiscalização das relações de trabalho.

De outra sorte, as ações anulatórias das notificações de recolhimento, pelas quais se discute o lançamento fiscal do débito relativo às contribuições de FGTS que foram objeto de Notificação Fiscal para Recolhimento do Fundo de Garantia e da Contribuição Social - NFGC, e da Notificação Fiscal para Recolhimento Rescisório do FGTS e das Contribuições - NRFC, conforme a vigente interpretação jurisprudencial, submetem-se à regra geral de competência da Justiça Federal, insculpida no artigo 109, I, 
da Constituição Federal de 1988, segundo a qual aos juízes federais compete processar e julgar as causas em que a União, entidade autárquica ou empresa pública federal forem interessadas na condição de rés, assistentes ou oponentes, exceto as de falência, as de acidente de trabalho e as sujeitas à Justiça Eleitoral e à Justiça do Trabalho.

Essa orientação foi firmada pelo Superior Tribunal de Justiça em diversos julgados de conflito de competência, no seu mister de dirimir os conflitos de competência entre a Justiça Federal e Justiça do Trabalho, nos termos do artigo 105. I, "d" da Constituição Federal. Nesse sentido, confira-se o extrato da decisão em Conflito de Competência entre a Justiça do Trabalho e a Justiça Federal para julgar ação anulatória de notificação de recolhimento do FGTS:

1. A ação anulatória onde não se discute qualquer penalidade administrativa, mas, sim, o lançamento fiscal do débito relativo às contribuições de FGTS que foi objeto de Notificação Para Depósito de Fundo de Garantia - NDFG, submete-se à regra geral de competência da Justiça Federal, insculpida no artigo 109, I, da Carta Magna de 1988, segundo a qual aos juízes federais compete processar e julgar: as causas em que a União, entidade autárquica ou empresa pública federal forem interessadas na condição de rés, assistentes ou oponentes, exceto as de falência, as de acidente de trabalho e as sujeitas à Justiça Eleitoral e à Justiça do Trabalho. 2. Hipótese em que se discute a cobrança de débito relativo aos depósitos do FGTS, previsto no artigo 15 da Lei n. $8.036 / 90$, e respectiva multa moratória e juros, previstos no artigo 22 , e não a multa administrativa estabelecida no artigo $23, \S 1^{\circ}$ da mesma lei. 3. Conflito conhecido para declarar a competência do Juízo da $11^{\mathrm{a}}$ Vara Federal Cível da Seção Judiciária do Estado de São Paulo, o suscitado ${ }^{94}$.

Essa dualidade de competências jurisdicionais pode levar a decisões díspares entre os órgãos da Justiça sobre os mesmos fundamentos de fato das demandas.

Com efeito, o auto de infração e as notificações de recolhimento decorrem da apuração dos mesmos fatos pela fiscalização do trabalho. Assim, auto de infração relativamente ao descumprimento da legislação do FGTS discutido na Justiça do Trabalho decorre de condutas omissivas do empregador em não depositar o percentual relativo ao FGTS referente aos recolhimentos mensais e rescisório, nos prazos legais, bem como de deixar de computar, para efeito de cálculo dos depósitos do FGTS parcela componente da remuneração, ou por deixar de efetuar os depósitos e os acréscimos legais

${ }^{94}$ STJ, CC 91166/SP, Rel. Min. Mauro Campbell Marques, DJe 28/10/2008. 
após notificado pela fiscalização. E, o crédito lançado em uma notificação de recolhimento pela autoridade fiscal do trabalho corresponde justamente ao fruto da apuração dos débitos realizada pela fiscalização do trabalho diante da conduta omissiva do empregador, e que geraram a lavratura do auto de infração e aplicação da multa punitiva correspondente.

Essa questão da dualidade de órgãos do Poder Judiciário competentes para conhecer e julgar as ações anulatórias dos autos de infração por descumprimento à legislação do FGTS, bem como as ações anulatórias dos débitos de FGTS notificados pela fiscalização do trabalho por meio das notificações de recolhimento (Notificação Fiscal para Recolhimento do Fundo de Garantia e da Contribuição Social - NFGC, e Notificação Fiscal para Recolhimento Rescisório do FGTS e das Contribuições - NRFC), representa ponto crítico no que diz respeito à efetividade do processo de recuperação dos créditos do FGTS e se encontra analisada no próximo capítulo em conjunto com o modelo de recuperação judicial dos créditos do FGTS pela União, submetido à mesma sistemática. 


\section{CAPÍTULO 4. A RECUPERAÇÃO JUDICIAL DOS CRÉDITOS DO FGTS PELA UNIÃO}

\subsection{Interesse jurídico econômico-social}

O presente capítulo tem por objeto a análise da dimensão judicial da relação jurídica obrigacional que se estabelece entre o Estado e o empregador referente à inadimplência quanto aos recolhimentos dos valores de depósitos mensais e rescisórios referentes ao Fundo de Garantia, bem como das multas aplicadas pela fiscalização do trabalho exercida pelo Ministério do Trabalho e Emprego, com fundamento no artigo 23, da Lei 8.036/90.

Após a confirmação administrativa do auto de infração e das notificações fiscais de recolhimento o crédito do FGTS é inscrito em dívida ativa da União pela Procuradoria-Geral da Fazenda Nacional, a qual perseguirá judicialmente, por meio de processo de execução fiscal, os valores devidos ao Fundo.

O modelo de cobrança judicial dos créditos do FGTS pela União, tanto os relativos às contribuições mensais e rescisórias devidos aos trabalhadores, quanto os relativos às multas trabalhistas, em primeira análise estampa interesse fiscal fundamentado na finalidade legal de financiamento das políticas econômico-sociais do sistema financeiro da habitação, saneamento básico, infraestruturas urbana e de base, relacionadas ao direcionamento de recursos a segmentos como os de transportes, portos, ferrovias e geração de energia, com vistas ao desenvolvimento nacional e à geração de empregos.

De todo modo, a finalidade trabalhista do FGTS deve ser conciliada com a finalidade econômico-social no modelo de recuperação dos créditos inscritos em dívida ativa da União, no sentido de evitar interpretações equivocadas e pontos críticos do sistema 
de cobrança.

O principal ponto crítico reside na dicotomia de cobrança judicial dos créditos do FGTS inscritos em dívida ativa da União.

Com efeito, os valores devidos ao Fundo de Garantia relativos aos depósitos mensais ou rescisórios são perseguidos pela União perante órgão da Justiça Federal.

De seu turno, os créditos decorrentes das multas administrativas aplicadas pela fiscalização do trabalho em face de descumprimento das regras do Fundo, consoante artigo 23, da Lei 8.036/90, são cobrados pela União perante órgão da Justiça do Trabalho.

A apontada dicotomia no modelo de recuperação dos créditos do FGTS pelo Estado, a ser detalhada no decorrer do presente capítulo, fruto de interpretação equivocada, traz insegurança jurídica, e revela inversão teleológica diante de uma análise das finalidades do Fundo de Garantia do Tempo de Serviço, com impacto na efetividade do modelo da recuperação pela União dos créditos devidos pelos empregadores.

Para tanto, no capítulo será dada ênfase à abordagem dos créditos do FGTS em juízo como objeto de execução fiscal, com distinção em dois pilares fundamentais, representados pela recuperação, perante órgão da Justiça Federal, dos créditos relacionados às contribuições mensais e rescisórias que devem ser objeto de depósito em conta vinculada do trabalhador, e pela recuperação dos créditos relacionados às penalidades administrativas perante órgão da Justiça do Trabalho, decorrentes dos autos de infração lavrados pela autoridade fiscal do trabalho.

A discussão perpassa por questões relativas à relação de trabalho como causa de pedir das ações judiciais e às implicações processuais nos embargos de devedor em execução fiscal de créditos do FGTS, nas ações anulatórias, e na identificação dos interesses envolvidos na recuperação dos créditos do FGTS buscada pela União em cotejo com as finalidades constitucionais e legais do Fundo. 


\subsection{Créditos do FGTS como objeto de execução fiscal}

\subsubsection{Representação judicial e extrajudicial do FGTS}

Administrativamente confirmados o auto de infração e as notificações fiscais emitidas pela fiscalização do trabalho o crédito do FGTS será inscrito em dívida ativa da União pela Procuradoria-Geral da Fazenda Nacional.

O FGTS integra o conceito de dívida ativa não-tributária da Fazenda Pública, uma vez que suas contribuições são, por força de disposição legal, inscritas em dívida ativa e cobradas mediante processo de execução fiscal submetido às regras previstas na Lei $\mathrm{n}^{\mathrm{o}} 6.830 / 80$ (LEF). E ainda, o artigo $2^{\circ}, \S 1^{\circ}$, da Lei de Execução Fiscal, determina que "qualquer valor, cuja cobrança seja atribuida por lei às entidades de que trata o artigol ${ }^{o}$, será considerado Dívida Ativa da Fazenda Pública", hipótese que amolda perfeitamente no artigo $2^{\circ}$, da Lei ${ }^{\circ}$ 8.844/94, que dispõe que o FGTS será cobrado pela Procuradoria-Geral da Fazenda Nacional.

O artigo $2^{\circ}$, da Lei 8.844/94, estabelece que é de atribuição da Procuradoria-Geral da Fazenda Nacional a inscrição em Dívida ativa dos débitos para com o Fundo de Garantia do Tempo de serviço - FGTS, competindo-lhe também a representação judicial e extrajudicial do FGTS, diretamente ou por intermédio da Caixa Econômica Federal, mediante convênio, para a correspondente cobrança, relativamente à contribuição e às multas e demais encargos previstos na legislação respectiva.

O citado dispositivo legal determinou que a representação judicial do FGTS compete à Procuradoria-Geral da Fazenda Nacional, a qual figura como órgão de direção superior da Advocacia-Geral da União, e exerce, dentre outras atribuições, a representação da União em causas fiscais, na cobrança judicial e administrativa dos créditos tributários e não-tributários. 
As atribuições da Procuradoria-Geral da Fazenda Nacional estão previstas nos artigos 12 e 13, da Lei Complementar $n^{\circ}$ 73/93, consistindo em: apurar a liquidez e certeza da dívida ativa da União de natureza tributária e não tributária, inscrevendo-a para fins de cobrança, amigável ou judicial; representar privativamente a União, na execução de sua dívida ativa de caráter tributário; examinar previamente a legalidade dos contratos, acordos, ajustes e convênios que interessem ao Ministério da Fazenda, inclusive os referentes à dívida pública externa, e promover a respectiva rescisão por via administrativa ou judicial; representar a União nas causas de natureza fiscal; e exercer as atividades de consultoria e assessoramento jurídicos no âmbito do Ministério da Fazenda e seus órgãos autônomos e entes tutelados.

Diante da inexistência de personalidade jurídica do Fundo de Garantia do Tempo de Serviço, e considerando que sua gestão e administração foi legalmente atribuída a órgãos distintos da Administração Pública Federal por conta de sua faceta de fonte de recursos para investimento público em ações e programas sociais de habitação, saneamento básico e infraestrutura urbana, o artigo $2^{\circ}$, da Lei 8.844/94, determinou competir à Procuradoria-Geral da Fazenda Nacional a representação judicial e extrajudicial do FGTS.

De se registrar, contudo, que nas hipóteses em o FGTS é demandante ou demandado judicialmente, a capacidade processual será exercida ora pela União, ora pela Caixa Econômica Federal, a depender da causa de pedir estar relacionada com o exercício de atribuições de cada uma dessas pessoas jurídicas em relação ao FGTS.

Assim, quando a causa de pedir estiver ligada ao exercício das competências listadas nos artigos $5^{\circ}$ e $6^{\circ}$ da Lei 8.036/90, pelo Conselho Curador do FGTS ou pelo Ministério das Cidades, a demanda deve ser ajuizada em face da União, porque os órgãos citados não possuem personalidade jurídica ${ }^{95}$. Da mesma forma, se a causa de pedir estiver ligada às atribuições de fiscalização e apuração das contribuições elencadas no artigo 23, da Lei 8.036/90, exercidas pelo Ministério do Trabalho e Emprego, a demanda também deverá ser ajuizada em face da União. Já se a causa de pedir em face do FGTS estiver relacionada a alguma das atribuições exercidas pela Caixa Econômica Federal, como nos casos de saques, esta deverá figurar no pólo passivo da demanda.

${ }^{95}$ JANTALIA, Fabiano. FGTS - Fundo de Garantia do Tempo de Serviço. Op. cit., p. 168. 
Noutro diapasão, uma vez inscrito em dívida ativa o crédito do FGTS a demanda deverá ser dirigida à União, nos termos da Lei 8.844/94 que atribuiu à Procuradoria-Geral da Fazenda Nacional a representação judicial e extrajudicial do FGTS, para a cobrança dos créditos do FGTS inscritos em dívida ativa, relativamente à contribuição e às multas e demais encargos previstos na legislação respectiva.

Entretanto, o citado dispositivo legal criou uma hipótese de substituição processual, permitindo à Procuradoria-Geral da Fazenda Nacional delegar, mediante convênio, a representação judicial e extrajudicial do FGTS à Caixa Econômica Federal, para a correspondente cobrança das contribuições e das multas e demais encargos previstos na legislação do Fundo de Garantia.

O conceito de substituição processual construído pela doutrina pode hoje se extrair exegeticamente do artigo $6^{\circ}$ do CPC: "Ninguém poderá pleitear, em nome próprio, direito alheio, salvo quando autorizado por lei". Substituto processual é quem, autorizado por lei, pleiteia em nome próprio direito alheio. O substituto processual é parte, definindo-se como tal quem pede a tutela jurisdicional, assim como aquele em face do qual é formulado o pedido. Em outras palavras, são partes o autor e o réu.

Destaca-se que a inscrição em dívida ativa de forma geral dos créditos relativos ao FGTS e a cobrança dos créditos constituídos por meio de autos de infração não integra o rol de atividades delegáveis, sendo atribuições privativas da Procuradoria-Geral da Fazenda Nacional.

A substituição processual prevista na lei tem razão histórica, visto que nas suas origens, por determinação da Lei 5.107/66, a gestão do FGTS competia ao Banco Nacional da Habitação (BNH), hoje extinto, sendo que o levantamento dos débitos porventura existentes e as respectivas cobranças administrativas ou judiciais eram atribuídas aos órgãos próprios da Previdência Social, que os perseguiam em juízo com os mesmos privilégios das contribuições devidas a Previdência Social. A Caixa Econômica Federal sucedeu o BNH como agente operador do FGTS, sendo que a atribuição de fiscalização e constituição dos créditos do Fundo de Garantia passou a ser do Ministério do Trabalho e Emprego, e a sua representação judicial e extrajudicial deixou de ser dos órgãos próprios da Previdência Social (IAPAS), passando a ser da Procuradoria-Geral da Fazenda Nacional, representante judicial e extrajudicial da União em matéria fiscal. 
O convênio de delegação previsto na Lei 8.844/94 foi firmado em 1996 entre a Procuradoria-Geral da Fazenda Nacional e a Caixa Econômica Federal, com vigência até os dias atuais. Em linhas gerais, pelo mencionado convênio a ProcuradoriaGeral da Fazenda Nacional passou a representar o FGTS na cobrança judicial dos créditos geridos pelo extinto $\mathrm{BNH}$, então promovida pelos órgãos próprios da Previdência Social, sendo delegada à Caixa Econômica Federal a cobrança dos novos créditos do Fundo, a partir da vigência da Lei 8.844/94. De se distinguir que, em que pese autorizado pela Lei Complementar $110 / 01^{96}$, as contribuições instituídas pela Lei Complementar $n^{\circ} 110 / 01$, que apresentam natureza nitidamente tributária, não estão contempladas no Convênio de delegação de cobrança judicial de créditos do FGTS celebrado entre a Procuradoria-Geral da Fazenda Nacional e a Caixa Econômica Federal.

Assim, a Procuradoria-Geral da Fazenda Nacional atua nas cobranças judiciais dos créditos de FGTS atrelados às respectivas contribuições sociais instituídas pela Lei Complementar $n^{\circ} 110 / 01$, rescisórias e mensais.

Esse sistema de cobrança dos créditos do FGTS pelo titular da representação judicial (Procuradoria-Geral da Fazenda Nacional) e pelo substituto processual (Caixa Econômica Federal), especialmente após a instituição das contribuições sociais pela Lei Complementar $n^{\circ} 110 / 01$, termina por bipartir o modelo de recuperação dos créditos do FGTS quanto ao pólo ativo da execução fiscal em prejuízo à sua efetividade.

\footnotetext{
${ }^{96}$ Para suprir saldos deficitários do FGTS decorrentes de pagamentos de condenações judiciais e acordos quanto à restituição e recomposição dos saldos das contas vinculadas em face de atualização monetária e expurgos inflacionários do período de $1^{\circ}$ de dezembro de 1988 a 28 de fevereiro de 1989 e do mês de abril de 1990, decorrente de planos econômicos da época, a Lei Complementar n. ${ }^{\circ} 110 / 01$, instituiu a contribuição social rescisória, devida pelos empregadores em caso de dispensa de empregado sem justa causa, à alíquota de 10\% sobre o montante de todos os depósitos devidos ao FGTS, durante a vigência do contrato de trabalho, acrescido das remunerações aplicáveis às contas vinculadas, bem como instituiu contribuição mensal devida pelos empregadores à alíquota de $0,5 \%$ sobre a remuneração devida, no mês anterior, a cada trabalhador, esta pelo prazo de sessenta meses decorridos de sua exigibilidade, que cessou em janeiro de 2007. O artigo $3^{\circ}$, da citada Lei Complementar estabelece que em relação às contribuições sociais de que tratam aplicam-se as disposições da Lei n. ${ }^{\circ} 8.036 / 90$, e da Lei n. ${ }^{\circ} 8.844 / 94$, inclusive quanto à sujeição passiva e equiparações, prazo de recolhimento, administração, fiscalização, lançamento, consulta, cobrança, garantias, processo administrativo de determinação e exigência de créditos tributários federais. Dessa forma a constituição e cobrança das contribuições instituídas pela Lei Complementar é a mesma adotada em relação aos créditos de FGTS.
} 
Nesse sentido é possível verificar execuções fiscais em face do mesmo empregador devedor promovidas pela Procuradoria-Geral da Fazenda Nacional e pela Caixa Econômica Federal que não seguem as mesmas diretrizes práticas de atuação.

Esse modelo apresenta ineficiência quanto ao controle de garantias processuais. Assim, numa execução fiscal de créditos do FGTS promovida pela União, por intermédio da Procuradoria-Geral da Fazenda Nacional, pode ocorrrer a contrição de bens para sua garantia e discussão por meio de embargos de devedor. De outro lado, noutra execução promovida pela Caixa Econômica Federal em face do mesmo empregador, por outros créditos de FGTS, pode ser oferecido para garantia o mesmo bem, sem ciência de que já garante outro crédito.

A intercorrência à efetividade das garantias apontada pode decorrer ainda de hastas públicas relativas aos mesmos bens levadas a efeito pelos distintos autores legitimados para as execuções fiscais dos créditos do FGTS.

E ainda, a defesa judicial em relação aos mesmos fundamentos lançados pelos devedores dos créditos de FGTS, sejam em ações declaratórias ou anulatórias, sejam em embargos às execuções fiscais, serão patrocinadas por entidades distintas, a União e a Caixa Econômica Federal, que seguem estruturas e se pautam por princípios de atuação próprios. A harmonia na defesa dos interesses do Fundo de Garantia do Tempo de Serviço é pressuposto para efetividade dos trabalhos de representação judicial, que fica prejudicado pelo considerado dualismo na legitimação processual autorizado pela lei.

Para sanar o problema há necessidade de unidade quanto à representação judicial do FGTS na condução dos processos de execução fiscal dos créditos relativos às contribuições mensais e rescisórias, o que demanda a revogação do vigente convênio de delegação firmando entre a PGFN e a CEF.

A especialização da União, por meio da Procuradoria-Geral da Fazenda Nacional, para as execuções fiscais, a qual detém a competência indelegável de inscrição em dívida ativa e criação do próprio título executivo dos créditos relativos ao FGTS deve se sobrepor ao papel de agente operador exercido pela Caixa Econômica Federal quanto à tarefa de representação judicial do Fundo de Garantia, em prol da harmonia na condução 
dos processos judiciais de cobrança e para evitar intercorrências prejudiciais à efetiva recuperação dos créditos.

\subsubsection{Créditos relacionados às penalidades administrativas e a}

\section{Justiça do Trabalho}

A cobrança judicial dos créditos do FGTS pela Procuradoria-Geral da Fazenda Nacional ou pela Caixa Econômica Federal segue o procedimento previsto na Lei de Execuções Fiscais, por se tratar de dívida ativa da União. Quanto às multas impostas pelas autoridades administrativas do trabalho, a obediência da cobrança ao disposto na Lei 8.030/80 também se extrai da disposição do artigo 642, da CLT.

Pode-se definir execução fiscal como o processo no qual os entes públicos buscam a satisfação do crédito público, apresentando-se como uma modalidade de execução de título extrajudicial, que tem por título executivo líquido, certo e exigível, a Certidão de Dívida Ativa. Os requisitos aos quais devem obedecer as Certidões de Dívida Ativa estão insertos no artigo 202 do Código Tributário Nacional.

A dívida ativa regularmente inscrita goza de presunção de certeza e liquidez. É o que dispõe o artigo $3^{\circ}$ da Lei 6.830/80. E não poderia ser diferente, até porque este atributo deriva da presunção de legitimidade de que gozam os atos administrativos. A presunção de legitimidade e de legalidade dos atos administrativos faz com que o ônus da prova em contrário seja do devedor. Tal presunção, como é cediço, é de natureza relativa, iuris tantum, devendo, entretanto, ser combatida com provas robustas. Meras alegações não elidem a presunção de certeza e liquidez de que desfruta a Certidão de Dívida Ativa. O artigo 204, parágrafo único, do Código Tributário Nacional, usa a expressão "prova inequívoca" para afastar a presunção de certeza e liquidez da Certidão de Dívida Ativa. 
Após a constituição e notificação do crédito público, seja ele tributário ou não, como no caso dos créditos do FGTS, se não satisfeito pelo devedor no tempo devido, nem impugnada sua exigência na esfera administrativa, nasce para o ente público o direito, na acepção de dever, de inscrever o crédito em dívida ativa, e, persistindo a inércia do devedor, executá-lo em juízo.

No âmbito da cobrança judicial dos créditos do FGTS pela União merece destaque a questão da competência de jurisdição para os executivos fiscais, uma vez que a vigente interpretação do texto constitucional quanto à matéria traduz equívoco que impacta negativamente no modelo de recuperação dos créditos do Fundo de Garantia do Tempo de Serviço.

De se rememorar a existência de duas categorias de créditos do FGTS constituídos pela fiscalização do trabalho objetos de cobrança judicial pela União. Uma categoria se compõe das multas aplicadas em relação ao descumprimento da legislação relativa ao FGTS, com fulcro no artigo 23, da Lei 8.036/90. Outra categoria é composta pelos créditos próprios dos trabalhadores a serem destinados em suas contas vinculadas individuais.

A recuperação dos créditos das multas punitivas aplicadas pela fiscalização do trabalho relativas ao FGTS, bem como dos valores devidos às contas vinculadas dos trabalhadores seguem o procedimento da Lei de Execuções Fiscais e são estampados na Certidão de Dívida Ativa da União, que lhes serve de título executivo extrajudicial.

Em que pese a identidade do procedimento judicial de recuperação de ambas as categorias dos créditos do FGTS consideradas, a vigente interpretação do texto constitucional quanto à competência jurisdicional para a execução dos mencionados créditos revela uma dualidade incompatível com a eficácia do modelo de sua recuperação.

Com efeito, a inscrição em dívida e a cobrança ou discussão judiciais decorrentes ocorrem separadamente em relação ao auto de infração e às notificações fiscais de recolhimento dos créditos do FGTS.

O inciso VII, do artigo 114, da Constituição Federal, com redação determinada pela Emenda Constitucional n ${ }^{\circ} 45 / 2004$, estabelece que todas as penalidades 
aplicadas pela fiscalização do trabalho em decorrência do descumprimento da legislação trabalhista pelo empregador, em caso de inadimplência, devem ser perseguidas no foro específico da Justiça do Trabalho.

Dessa forma, a multa objeto do auto de infração dará ensejo à inscrição em dívida ativa da União, na qualidade de penalidade administrativa imposta pela fiscalização do trabalho, a qual será cobrada judicialmente em sede de execução físcal pela Procuradoria-Geral da Fazenda Nacional no âmbito da Justiça do Trabalho, com fundamento no artigo 114, VII, da Constituição Federal, fruto da Emenda Constitucional n. ${ }^{\circ} 45 / 2004$, que determina:

Artigo 114. Compete à Justiça do Trabalho processar e julgar: (...)

VII - as ações relativas às penalidades administrativas impostas aos empregadores pelos órgãos de fiscalização das relações de trabalho; (...)

Por óbvio, alberga essa determinação constitucional as multas aplicadas em relação ao descumprimento da legislação relativa ao FGTS, com fulcro no artigo 23, da Lei 8.036/90, pois apresentam natureza de penalidades administrativas impostas aos empregadores pelos órgãos de fiscalização das relações de trabalho.

Registre-se que o alcance do citado dispositivo constitucional é amplo para abrigar a competência da Justiça do Trabalho para as ações de cobrança das penalidades impostas pela fiscalização do trabalho, mediante execução fiscal, bem como ações declaratórias de regularidade das relações de trabalho e ações anulatórias dos autos de infração ${ }^{97}$.

De outra sorte, os créditos originários do não recolhimento das contribuições mensais ou rescisória, após a inscrição em dívida ativa da União são cobrados por meio de execução fiscal promovida pela Procuradoria-Geral da Fazenda Nacional, ou pela Caixa Econômica Federal, no âmbito do Poder Judiciário Federal, com fundamento no artigo 109, I, da Constituição Federal, que determina:

\footnotetext{
${ }^{97}$ MANUS, Pedro Paulo Teixeira; ROMAR, Carla Teresa Martins; GITELMAN, Suely Ester. Competência da Justiça do Trabalho e EC n 45/2004. São Paulo: Atlas, 2006, p. 71.
} 
Artigo 109. Aos juízes federais compete processar e julgar:

I - as causas em que a União, entidade autárquica ou empresa pública federal forem interessadas na condição de autoras, rés, assistentes ou oponentes, exceto as de falência, as de acidentes de trabalho e as sujeitas à Justiça Eleitoral e à Justiça do Trabalho; (...)

Neste ponto impõe-se desvendar a validade dos fundamentos da diversidade da cobrança judicial dos créditos do FGTS, as inconsistências processuais decorrentes e os reflexos na sua efetividade.

Teleologicamente a inserção no texto constitucional da competência da Justiça do Trabalho para processar e julgar as ações relativas às penalidades administrativas impostas aos empregadores pelos órgãos de fiscalização das relações de trabalho busca garantir a concentração e especialização judiciária em relação à matéria juslaboralista.

A reforma do Poder Judiciário veiculada pela Emenda Constitucional $\mathrm{n}^{\mathrm{o}}$ 45/2004 deixa claro, como ponto relevante, a intenção de evitar ao máximo a competência concorrente entre ramos do Poder Judiciário, que pode levar a decisões conflitantes ${ }^{98}$.

Anteriormente à vigência da redação do inciso VII, do artigo 114, determinada pela Emenda Constitucional nº45/2004, era da Justiça Federal a competência para processar e julgar as execuções fiscais promovidas pela União para a cobrança das multas relativas ao FGTS aplicadas pela fiscalização do trabalho, bem como as ações declaratórias e anulatórias correspondentes aos autos de infração lavrados pelo Ministério do Trabalho e Emprego.

Assim, como fundamento de suas sentenças em incidentes e ações de defesa em execução físcal, ou mesmo em ações anulatórias, o juiz federal decidia sobre questão atinente à existência da relação de emprego, como pressuposto do auto de infração ou da certeza do crédito executado, referente à multa relativa ao FGTS aplicada pelo auditor fiscal do trabalho.

Mas também, de outro lado, a relação de emprego que serviu de parâmetro para a aplicação da multa pela fiscalização do trabalho poderia ser objeto de

\footnotetext{
${ }^{98}$ MANUS, Pedro Paulo Teixeira; ROMAR, Carla Teresa Martins; GITELMAN, Suely Ester. Competência da Justiça do Trabalho e EC no 45/2004. Op. cit., p. 75.
} 
discussão em sede de ação trabalhista autônoma no âmbito da Justiça do Trabalho, ocasionando a possibilidade de decisões díspares entre os órgãos do Poder Judiciário, sobre a mesma questão.

Com a determinação pelo constituinte derivado por meio da Emenda Constitucional no 45/2004 da competência da Justiça do Trabalho para conhecer e julgar as ações relativas às penalidades administrativas impostas aos empregadores pelos órgãos de fiscalização das relações de trabalho, a Justiça Federal deixa de ter competência para julgar as mesmas ações, reservando-se o conhecimento e julgamento de matéria justrabalhista subjacente ao órgão especializado do Poder Judiciário.

Pelo texto expresso do inciso VII, do artigo 114 da Constituição Federal, encontra-se fixada, sem sombra de dúvidas, a competência da Justiça do Trabalho para conhecer e julgar as ações correspondentes aos créditos do FGTS decorrentes das multas aplicadas pela fiscalização do trabalho, mediante a lavratura de autos de infração.

Frise-se que essa determinação da competência da Justiça do Trabalho inserida pelo constituinte derivado representou avanço no modelo de recuperação dos créditos das multas do FGTS aplicadas pela fiscalização do trabalho, pois concentrou no seio da justiça especializada o conhecimento da matéria laboral, ligada à relação de trabalho que serve de base para a incidência do regime do Fundo de Garantia do Tempo de Serviço, e dessa forma afastou a competência da Justiça Federal para a apreciação da matéria juslaboralista de fundo das multas trabalhistas correspondentes ao FGTS, prevenindo a insegurança jurídica e o desprestígio do Poder Judiciário frente a decisões díspares.

De se apontar que a previsão de competência da Justiça do Trabalho para a cobrança das multas trabalhistas aplicadas pelo Ministério do Trabalho e Emprego representou uma ampliação do rol dos títulos executivos extrajudiciais admitidos pelo processo do trabalho, uma vez que a execução das multas trabalhistas têm por supedâneo a Certidão de Dívida Ativa da União, prevista como título executivo extrajudicial pelo inciso VI, do artigo 585, do Código de Processo Civil. 


\subsubsection{Créditos relacionados aos depósitos vinculados mensais e} rescisórios e a Justiça Federal

Feitas as considerações sobre a cobrança das multas trabalhistas do FGTS impõe-se conduzir as reflexões sobre o modelo de recuperação judicial dos créditos do FGTS, não recolhidos pelo empregador, que são constituídos pela fiscalização do trabalho por meio das notificações fiscais de recolhimento, seja a Notificação Fiscal para Recolhimento do Fundo de Garantia e da Contribuição Social - NFGC, seja a Notificação Fiscal para Recolhimento Rescisório do FGTS e das Contribuições - NRFC.

A interpretação doutrinária e jurisprudencial predominante orienta-se no sentido de que, quanto às ações judiciais relativas aos créditos do FGTS originários das notificações fiscais, a competência jurisdicional para o seu conhecimento e julgamento é da Justiça Federal e não da Justiça do Trabalho, pois as execuções fiscais das citadas notificações fiscais e demais ações judiciais não se encontram inseridas na competência da Justiça do Trabalho.

Cumpre esclarecer que a Súmula 349, do Superior Tribunal de Justiça STJ, chancelou a competência da Justiça Federal para a cobrança judicial dos créditos do FGTS objetos das notificações fiscais, ao estabelecer que "compete à Justiça Federal ou aos juízes com competência delegada o julgamento das execuções fiscais de contribuições devidas pelo empregador ao FGTS”.

Para o Superior Tribunal de Justiça a alteração promovida pela Emenda Constitucional 45/2004 no artigo 114, da Constituição Federal de 1988, não abalou a fixação da competência da Justiça Federal para processar e julgar as execuções fiscais de créditos do FGTS dos trabalhadores, eis que os depósitos para o FGTS representam obrigação legal do empregador em benefício do empregado, havendo, entretanto, nítido interesse federal na higidez do Fundo, cujos recursos são utilizados na implementação de políticas habitacionais vinculadas ao Sistema Financeiro da Habitação - SFH. 
E ainda, o fundamento da orientação jurisprudencial objeto da citada Súmula apóia-se na ideia de que a execução fiscal das dívidas do FGTS, a cargo da União, ou da Caixa Econômica Federal, não se confunde com a relação de trabalho subjacente, já que não envolve diretamente empregador e empregado.

De se citar também o entendimento exarado pelo ministro Teori Albino Zavascki, o qual observa que a ação de cobrança proposta pelo Poder Público em favor do FGTS tem natureza estatutária e não contratual. Segundo o ministro, a relação jurídica que se estabelece entre o Fundo e o empregador, da qual decorre a obrigação de recolhimento de contribuições, fundamenta-se na lei e não na relação de trabalho ${ }^{99}$.

A doutrina jurídica nacional também caminha no sentido da orientação jurisprudencial trazida à tona ${ }^{100}$, sob o argumento de que as ações de execução fiscal ajuizadas para cobrança dos débitos dos empregadores com o FGTS “continuam a ser processadas e julgadas pela Justiça Federal, tendo em vista que a cobrança destas dívidas não se confunde com a relação de trabalho subjacente, por se tratar de uma relação de Direito Público" 101 .

Merece reflexão crítica o atual modelo de recuperação judicial dos créditos devidos ao FGTS promovida pela União em sede de órgãos do Poder Judiciário distintos, especialmente no que tange aos critérios constitucionais de determinação de competência jurisdicional, bem como aos interesses perseguidos na recuperação dos créditos e as finalidades legais e constitucionais do Fundo de Garantia do Tempo de Serviço.

No contexto geral da cobrança e discussão dos créditos do FGTS na sua fase judicial, tanto a empreendida pelo próprio trabalhador quanto pela União é possível verificar que as discussões giram em torno da mesma causa de pedir, identificada na relação de trabalho geradora da remuneração base da incidência dos recolhimentos para o Fundo de Garantia do Tempo de Serviço.

\footnotetext{
${ }^{99}$ STJ. Súmula 349, julgado em 11/06/2008, , Rel. Min. Luiz Fux, DJe 19/06/2008.

${ }^{100}$ MARTINS, Sérgio Pinto. Manual do FGTS. Op. cit., p. 244.

${ }^{101}$ JANTAIA, Fabiano. FGTS - Fundo de Garantia do Tempo de Serviço. Op. cit., p. 160.
} 
O critério material é aquele que orienta a determinação constitucional da competência da Justiça do Trabalho, tendo sido alargado pela Emenda Constitucional $45 / 2004$ para abarcar de forma ampla as diversas relações de trabalho ${ }^{102}$.

Anteriormente à Constituição Federal de 1988 prevalecia no ordenamento jurídico o exclusivo critério ratione personae para definição da competência da Justiça Federal. Segundo estabelecia o $§ 2^{\circ}$,do artigo 125, da Constituição de 1967, com a Emenda n. $.^{\circ} 01 / 69$, se a União interviesse nas causas propostas perante outros juízes, como assistente ou opoente, passaria a causa a ser da competência do juiz federal respectivo, deslocando-se a competência.

Com a promulgação da Constituição Federal de 1988, evidencia-se alteração no critério de determinação da competência jurisdicional, prevalecendo-se a competência dos juízes especializados, determinada essencialmente em razão da matéria.

Nesse sentido, o artigo 109, I, da atual Constituição Federal, é expresso ao estabelecer que compete os juízes federais processar e julgar as causas em que a União, entidade autárquica ou empresa pública federal forem interessadas na condição de autoras, rés, assistentes ou oponentes, excepcionando as causas de falência, as de acidentes de trabalho e as sujeitas à jurisdição especializada da Justiça Eleitoral e da Justiça do Trabalho.

O crédito de FGTS objeto das notificações fiscais, enquanto parcela patrimonial, excetuada a parcela acessória de natureza tributária instituída pela LC 110/01, pertence necessariamente ao trabalhador, ainda que sobre ele tenha disposição limitada por lei. Enquanto crédito, o interesse do trabalhador está claramente evidenciado na relação de trabalho, uma vez que é esta que dá origem a tal obrigação.

Não se concebe a existência de créditos do FGTS sem relação de trabalho. Assim, a competência da Justiça do Trabalho, essencialmente definida em razão da matéria, deve prevalecer.

Apresenta o FGTS sua origem natural na relação de trabalho, uma vez que inexistente esta não haveria tal obrigação, e considerando que tal vínculo jurídico

${ }^{102}$ Exclui-se, por força de interpretação constitucional, os servidores públicos estatutários e os de contratação especial, isto é, não celetistas, conforme decisão do Supremo Tribunal Federal na ADI 3395-6-DF. 
marca a competência da Justiça especializada, inclusive quanto aos entes de direito público externo e da administração pública direta e indireta, nada obsta que a Fazenda Pública, em execuções fiscais promovidas para o recolhimento do FGTS devido pelo empregador, tenha seus processos tramitando regularmente pela Justiça do Trabalho.

Conforme acima afirmado, a Constituição Federal de 1988 atribuiu prevalência da competência da justiça especializada em face da justiça comum federal ou estadual, dando especial relevo ao critério material em relação ao critério pessoal.

Dessa forma não é o fato de figurar a União ou a Caixa Econômica Federal no pólo ativo da execução dos créditos do FGTS objeto das notificações fiscais que determinará a competência da Justiça Federal, devendo prevalecer a competência da Justiça do Trabalho, fixada em razão da matéria e não em razão da pessoa.

De todo modo, a mudança no rumo interpretativo quanto à questão da competência para as ações atinentes aos créditos do FGTS das contas vinculadas dos trabalhadores não se sustenta apenas quanto à prevalência do critério material da determinação constitucional da competência de jurisdição, ou quanto à indispensabilidade de uma relação de trabalho subjacente ao nascimento dos créditos do Fundo de Garantia do Tempo de Serviço. Há necessidade do resgate da natureza jurídica do FGTS diante de sua finalidade constitucional.

No que tange às finalidades do FGTS, consoante balizas fixadas nos capítulos anteriores, pode-se identificar uma natureza multidimensional, cujas finalidades podem ser bipartidas num espectro mais estreito de interesse e proteção do trabalhador e num espectro mais alargado de interesse público no financiamento de programas sociais de e desenvolvimento econômico.

Sob o prisma do trabalhador, a finalidade precípua do Fundo de Garantia revela-se como crédito compensatório do tempo de serviço do trabalhador para albergá-lo diante de contingências legalmente previstas e servir como regime de indenização por sua dispensa arbitrária ou sem justa causa, no sentido da proteção do emprego. Essa finalidade trabalhista do Fundo de Garantia do Tempo de Serviço encontra esteio constitucional, consoante previsão do artigo $7^{\circ}$, I, da Constituição Federal, e do artigo 10, I do ADCT.

Ao passo que sob o prisma do interesse econômico-social sobressai ao 
FGTS a destinação e aplicação pelo Poder Público Federal dos seus recursos como fonte de investimentos destinados a subsidiar políticas econômico-sociais do sistema financeiro da habitação, saneamento básico, infraestrutura urbana e infraestrutura de base relacionada ao direcionamento de recursos a segmentos como os de portos, ferrovias e geração de energia. Essa finalidade pública e social é evidenciada pela lei ordinária de regência do FGTS.

Anote-se que a administração do FGTS foi atribuída pela legislação a diversos órgãos do Poder Público Federal (Conselho Curador, Ministério do Trabalho, Ministério das Cidades, Caixa Econômica Federal), e a representação judicial e extrajudicial foi atribuída à Procuradoria-Geral da Fazenda Nacional, órgão jurídico de representação da União, em razão da faceta do interesse de promover com recursos do FGTS o financiamento dos programas de desenvolvimento econômico e social dos setores legalmente determinados.

Sem dúvidas, numa análise interpretativa literal é possível sustentar a competência da Justiça Federal para a execução dos créditos do FGTS objeto das notificações fiscais, em razão da presença da União ou da Caixa Econômica Federal como exequentes, bem como em razão do nítido interesse federal na higidez do Fundo, cujos recursos são utilizados na implementação de políticas econômico-sociais.

Entretanto, como aqui apontado, a Constituição Federal quando do elenco das competências jurisdicionais primou pelo critério material. E ainda, não é possível justificar a prevalência do interesse econômico-social do FGTS em face do interesse social trabalhista de matiz constitucional.

O referencial adotado deve ser o FGTS como direito fundamental do trabalhador, previsto no artigo $7^{\circ}$, III, da Constituição Federal. A finalidade trabalhista do FGTS apresenta estatura constitucional, ao passo que a sua finalidade de fomento econômico e social tem fundamento em lei ordinária. Os depósitos para o FGTS constituem um crédito do trabalhador, decorrente da execução do seu contrato de trabalho, afim de ampará-lo nas hipóteses legalmente previstas, e não deve ser confundido com receita pública ${ }^{103}$.

\footnotetext{
${ }^{103}$ SÜSSEKIND, Arnaldo; MARANHÃO, Délio; VIANNA, Segadas; TEIXEIRA, Lima. Instituições de direito do trabalho. Op. cit., p. 685.
} 
Diante do exposto, de se concluir que a interpretação dada pelo Superior Tribunal de Justiça, por meio da Súmula 349, parte de premissa equivocada, pois segrega os interesses do trabalhador dos interesses da União e fazer prevalecer a regra ratione personae, que afirma a competência da Justiça Federal.

A interpretação quanto à competência para a execução pelo Poder Público dos créditos do FGTS devidos ao trabalhador deve ser imbuída do mesmo espírito com que o constituinte derivado, por meio da Emenda Constitucional $n^{\circ} 45 / 2004$, determinou a competência da Justiça do Trabalho para processar e julgar as ações relativas às penalidades administrativas impostas aos empregadores pelos órgãos de fiscalização das relações de trabalho, no sentido de garantir a concentração e especialização judiciária em relação à matéria juslaboralista e evitar a competência concorrente entre ramos do Poder Judiciário, que pode levar a decisões conflitantes.

Basta tomar como hipótese o caso de uma ação de execução fiscal de créditos decorrentes das notificações fiscais de recolhimento do FGTS emitidas pela fiscalização do trabalho, em que o empregador nega a existência da relação de emprego considerada pelo auditor do trabalho como base de incidência do regime do Fundo de Garantia. Se a ação tramitar no juízo federal, o magistrado decidirá como questão de fundo à execução físcal sobre a existência ou não da relação de emprego que sustenta a notificação fiscal de recolhimento do FGTS, tomando como fundamento de sua decisão o juízo sobre relação de trabalho.

A mesma relação de emprego eventualmente não confirmada pelo magistrado federal como fundamento de sua decisão na hipótese considerada pode ser objeto de uma ação trabalhista em que se verifica o reconhecimento judicial da relação de emprego. Essas decisões díspares entre os órgãos jurisdicionais acarreta insegurança jurídica e desprestígio ao Poder Judiciário.

De se registrar que tanto nas decisões proferidas nos embargos de devedor interpostos em face das execuções fiscais movidas para cobrança das multas do FGTS na Justiça do Trabalho quanto nas ações declaratórias ou anulatórias movidas na Justiça Federal em face das notificações fiscais do Fundo conduzir-se-á para esse modelo de inconsistências. É factível que um auto de infração de FGTS seja desconstituído pela Justiça do Trabalho, mas as correspectivas notificações de recolhimento não o sejam pela 
Justiça Federal, e a recíproca se faz verdadeira. Definitivamente a Justiça Federal não detém competência para decidir sobre relação de emprego.

Ainda no âmbito das presentes considerações revela-se importante observar que no vigente modelo de dualidade de competência jurisdicional para recuperação dos créditos do FGTS pela União verifica-se inversão teleológica quanto ao resultado das demandas e os fins perseguidos com a cobrança, considerada a destinação final dos recursos arrecadados.

Assim, na Justiça do Trabalho a execução fiscal das multas oriundas de autos de infração lavrados pela autoridade administrativa laboral em face do não recolhimento das contribuições do FGTS denota o caráter de punição da conduta ilegal do empregador diante do descumprimento das regras do Fundo.

Os valores arrecadados mediante as execuções fiscais promovidas no seio da Justiça do Trabalho para recuperação de créditos do FGTS decorrentes das penalidades administrativas impostas pela fiscalização do trabalho ao ingressarem no Tesouro Nacional devem ser conduzidos ao Fundo de Garantia do Tempo de Serviço como receitas incorporadas, não constituindo receitas que integram as contas vinculadas dos trabalhadores. Essas são receitas fiscais do Fundo de uma forma geral.

De outro lado, a execução fiscal dos créditos referentes às contribuições mensais e rescisórias devidas pelos empregadores, levada a efeito no âmbito da Justiça Federal nos termos da Súmula 349, do Superior Tribunal de Justiça, possibilita a satisfação do direito de crédito do trabalhador, eis que os valores arrecadados são destinados ao Fundo e individualizados nas respectivas contas vinculadas dos trabalhadores. Essas são receitas de natureza trabalhista.

Dessa forma, inobstante sua vocação constitucional para a garantia da efetividade dos direitos trabalhistas a Justiça do Trabalho é palco para recuperação dos créditos que não satisfarão os trabalhadores diretamente, ao passo que a Justiça Federal é competente para processar as execuções fiscais que buscam recuperar os créditos do FGTS devidos aos trabalhadores.

O modelo de recuperação dos créditos do FGTS devidos pelos empregadores deve ser guiado pela natureza de direito fundamental do Fundo, diante do 
comando constitucional do artigo 7..$^{\circ}$, inciso III, considerando-se que tais créditos apresentam os mesmos privilégios do crédito trabalhista, conforme determinado pelo artigo $2 .^{\circ}, \S 3 .^{\circ}$ da Lei $8.844 / 94$.

Diante desses fundamentos não se justifica a manutenção da interpretação da competência da Justiça Federal ou dos juízes com competência delegada para o julgamento das execuções fiscais de contribuições devidas pelo empregador ao FGTS.

Em suma, para a unificação de competência jurisdicional quanto à recuperação dos créditos do FGTS promovida pela Fazenda Pública Nacional devem ser levados em consideração: a imprescindibilidade da relação laboral como pressuposto dos créditos do FGTS; a prevalência do critério material na determinação constitucional da competência de jurisdição; a prevalência do FGTS como direito fundamental do trabalhador em sua finalidade compensatória do seu tempo de serviço para albergá-lo diante de contingências legalmente previstas e servir como regime de indenização por sua dispensa arbitrária ou sem justa causa; a necessidade de se evitar competência concorrente entre os diversos ramos do Poder Judiciário, para prevenir a ocorrência de decisões conflitantes e insegurança jurídica; bem como a evidente inversão teleológica do modelo dicotômico de competência jurisdicional para a recuperação dos créditos do Fundo de Garantia, pois em que pese haver o interesse econômico-social perseguido pela União na cobrança dos valores das contribuições devidas ao FGTS perante a Justiça Federal, em ultima ratio seu destino é a conta vinculada para satisfação dos trabalhadores.

O modelo de recuperação dos créditos do FGTS mais consistente e efetivo demanda a concentração na Justiça do Trabalho da competência para processar e julgar as ações que tenham por objeto os créditos do Fundo relativos às contas vinculadas dos trabalhadores estampados em notificações fiscais de recolhimento expedidas pela fiscalização do trabalho, uma vez que se tratam de ações que sempre apresentam como subjacente uma relação de trabalho, nos termos do inciso I, do artigo 114, da Constituição Federal, e que têm por objeto o FGTS como direito fundamental do trabalhador. 


\subsection{Reflexos na execução fiscal do pagamento direto ao trabalhador dos créditos do FGTS em ação trabalhista}

Merece destaque o debate acerca do pagamento dos valores referentes ao FGTS diretamente ao empregado, determinado no seio das ações trabalhistas ajuizadas pelos trabalhadores, contemplando recolhimentos referentes ao Fundo de Garantia e seu impacto no tocante às execuções fiscais dos créditos do FGTS.

Os artigos 15 e $18, \S 1^{\circ}$, da Lei $n^{\circ} 8.036 / 90$ dispõem que a importância relativa ao recolhimento mensal do FGTS e, na hipótese de dispensa imotivada, o valor correspondente à multa de 40\% (quarenta por cento), devem ser depositados em conta bancária vinculada do trabalhador.

De seu turno, o artigo 26, parágrafo único, da Lei $\mathrm{n}^{\circ}$ 8.036/90 dispõe, in verbis, que "nas reclamatórias trabalhistas que objetivam o ressarcimento de parcelas relativas ao FGTS, ou que, direta ou indiretamente, impliquem essa obrigação de fazer, o juiz determinará que a empresa sucumbente proceda ao recolhimento imediato das importâncias devidas a tal título".

$\mathrm{Na}$ redação do dispositivo o emprego da expressão recolhimento evidencia que no caso de o trabalhador ajuizar ação trabalhista pleiteando o pagamento de parcelas relativas ao FGTS o valor devido também será depositado, pelo empregador condenado, em conta vinculada.

Inobstante a regra legal do depósito obrigatório dos valores referentes ao FGTS em conta vinculada do trabalhador na Caixa Econômica Federal, na prática verificase o pagamento dos valores relativos ao FGTS diretamente ao trabalhador, determinado em ação trabalhista.

Numa análise superficial, tal providência pode não traduzir nenhum prejuízo. E mais, pode parecer mais benéfica ao trabalhador quanto à satisfação do seu crédito, pois, seria uma medida meramente burocrática exigir-se que, depois de extinto o contrato de trabalho, a empresa condenada judicialmente, e que foi inadimplente durante determinado período, fizesse os depósitos na conta vinculada do trabalhador obrigando-o à 
comparecer à Caixa Econômica Federal apenas para efetuar o saque.

Contudo, o pagamento direito das verbas do FGTS ao trabalhador em sede de ação trabalhista é providência que não se coaduna com as finalidades do Fundo de Garantia do Tempo de Serviço, afronta expressa determinação legal, e traz impactos negativos no modelo de recuperação dos créditos do FGTS pelo Poder Público.

O pagamento das contribuições do FGTS realizado diretamente ao trabalhador em sede de ação trabalhista pode ensejar a hipótese de eventual cobrança em duplicidade dos mesmos valores em execução fiscal movida pela União, ou Caixa Econômica Federal, em face do empregador, o que demandará dilação probatória por parte deste para demonstração do efetivo pagamento, acarretando incidentes na execução, que prejudicam a celeridade processual e a satisfação do crédito, acarretando ônus aos cofres públicos com exigência do pagamento da sucumbência incidente sobre a cobrança em duplicidade.

Os tribunais brasileiros reconhecem o pagamento do FGTS diretamente ao trabalhador em sede de ações trabalhistas e determinam que demonstrado este fato as execuções fiscais não podem prosseguir quanto ao valor pago, sob pena de configuração de pagamento em duplicidade e enriquecimento sem causa, além de nulidade, pois o título executivo não se apresenta líquido. Nesse sentido confira-se o aresto abaixo, representativa da interpretação dada pelo Poder Judiciário ao fato em análise:

1. A parte Autora argumenta a nulidade do título executivo sustentando a sua desconstituição por falta de liquidez e certeza. Alegou exceção de pré-executividade, sendo que os valores cobrados a título de FGTS já foram pagos na ação judicial, que a dívida não é líquida nem certa, uma vez que a CDA não indica o número do livro nem a folha que foi inscrita. 2. O juiz de primeiro grau julgou a ação improcedente sustentando que a dívida do FGTS não restou comprovadamente quitada junto à Caixa Econômica Federal e que o título não foi desconstituído. 3. O pagamento dos valores a título de FGTS, a quitação, por meio de ação trabalhista diretamente ao empregado deve ser aceita, pois entendimento diverso acarretaria ao embargante o ônus de efetuar dois pagamentos pelo mesmo fato. 4. Concedido provimento à apelação ${ }^{104}$.

Inobstante o contorno jurisprudencial apontado, o pagamento das verbas

${ }^{104}$ TRF $3^{\text {a }}$ Região, AC 573367, Processo n ${ }^{\text {o }} 200003990112170,1^{\text {a }}$ Turma, Rel. Juiz Luiz Stefanini, DJU 22.03 .05 , p. 278 . 
relativas ao FGTS diretamente ao trabalhador em ação trabalhista pode representar pagamento indevido dos consectários da mora e embaraço na sua cobrança, uma vez que, os juros moratórios, a correção monetária e as multas cobradas do empregador em atraso no pagamento de valores devidos ao FGTS revertem para o próprio fundo, e não para o empregado $^{105}$.

Assim, se a correção, os juros moratórios e a multa do artigo 22, da Lei 8.036/90, revertem para FGTS e não para as contas vinculadas, torna-se ilegítimo o pagamento direto ao empregado determinado em ação trabalhista, pois ele não é o titular do direito. Ocorrendo o pagamento direto ao trabalhador quanto aos consectários da mora a execução fiscal dos mesmos valores promovida pela União ou Caixa Econômica Federal será devida, pois o trabalhador não é o titular do direito, e assim não há que se falar em duplicidade de pagamento. Entretanto, essa situação distorce o modelo de cobrança integral dos créditos devidos ao Fundo de Garantia pelos empregadores, além de prejudicar o ajuizamento de ações executivas em razão de alçada fixada pelo Comitê Gestor, atualmente estabelecida no patamar mínimo de $\mathrm{R} \$ 2.000,00$ (dois mil reais).

Corrobora a observância da necessidade legal dos depósitos do FGTS na conta vinculada do trabalhador a teoria do Fundo de Garantia como uma forma de poupança forçada, segundo a qual os depósitos do FGTS significam uma reserva financeira compulsória do trabalhador a fim de auxiliá-lo em determinadas contingências sociais, tais como o desemprego involuntário, aposentadoria, falecimento, desenvolvimento de doença grave e outras hipóteses legalmente previstas.

Além do mais, não é de se olvidar que os recursos recolhidos ao Fundo de Garantia do Tempo de Serviço são também utilizados para financiar a construção de habitações populares, obras de saneamento básico e de infraestrutura urbana. Se ocorre o pagamento direto ao trabalhador evidencia-se paralelamente prejuízo ao saldo do Fundo.

Assim, em virtude dessa natureza de reserva financeira forçada em benefício do trabalhador e da sociedade, o levantamento dos depósitos do FGTS apenas é permitido nas hipóteses constantes do artigo 20, da Lei 8.036/90, sendo que, somente em casos excepcionais é possível a liberação do saldo do FGTS em situações não elencadas no

\footnotetext{
${ }^{105}$ STJ, AC No 2003.70.02.000562-6/PR, Rel. Des. Otávio Pamplona, 2 ${ }^{\mathrm{a}}$ Turma, D.E. 04.12.2008; e EREsp 418524/RS, Rel. Ministro João Otávio de Noronha, 1ª Sessão, DJ 13.12.2004, p. 200.
} 
mencionado preceito legal.

E ainda, não se justifica o pagamento dos valores relativos ao FGTS diretamente ao trabalhador por decisão judicial ou acordo em sede de ação trabalhista ao argumento da celeridade do levantamento dos créditos. Para fundamentar o pagamento direto far-se-ia necessária a comprovação da existência de alguma das hipóteses autorizativas do saque, previstas no artigo 20, da Lei 8.036/90, e, nem sempre há essa demonstração em juízo, tampouco as verbas de FGTS reclamadas em juízo pressupõem a extinção do contrato por dispensa sem justa causa, como hipótese autorizativa de saque prevista legalmente.

Esse entendimento tem sido objeto de consideração pela jurisprudência trabalhista e o Tribunal Superior do Trabalho já decidiu que "nas reclamações trabalhistas em que há pedido de pagamento de valores relativos ao FGTS, o depósito deve ser feito em conta vinculada do reclamante, observando-se o teor do artigo 26, parágrafo único, da Lei $n^{\circ} 8.036 / 90^{, 106}$.

Dessa forma, considerando o fim social da norma jurídica que determina o depósito compulsório dos valores referentes ao FGTS, bem como que as verbas de FGTS perseguidas em ação trabalhista nem sempre se submetem às hipóteses legais de saque, e tendo em vista que o pagamento realizado diretamente ao trabalhador pode ensejar a cobrança do empregador em duplicidade por meio de execução fiscal pela União, ou Caixa Econômica Federal e trazer sérios impactos processuais e nos cofres públicos, a solução a ser observada é o estrito cumprimento dos ditames da Lei 8.036/90, no sentido de que os valores relativos ao FGTS devem ser obrigatoriamente depositados na conta vinculada do trabalhador.

${ }^{106}$ TST, RR 1482700-20.2007.5.09.0651, 5 Turma, Rel. Kátia Magalhães Arruda, DJE 28.08.2009. 


\section{CONCLUSÕES}

O desenvolvimento do presente trabalho teve como propósito trazer reflexões jurídicas sobre tema ainda pouco explorado, consistente no modelo de recuperação dos créditos do FGTS relativos às contribuições mensais, rescisórias e multas aplicadas pela fiscalização do trabalho em face dos empregadores, com o fim desvendar os pontos críticos que interferem na efetividade do sistema de cobrança e apontar soluções que conciliem os interesses envolvidos em cotejo com as finalidades constitucionais e legais do Fundo de Garantia no seu viés de direito fundamental do trabalhador.

O Fundo de Garantia do Tempo de Serviço (FGTS) foi instituído pela Lei 5.107/66 num contexto de reformas estruturais e serviu como instrumento de flexibilização do regime de dispensas no país, opcional à estabilidade decenal garantida por lei. Com a promulgação da Constituição de 1988, o Fundo de Garantia do Tempo de Serviço foi alçado à categoria de direito fundamental do trabalhador e se tornou regime único e obrigatório a toda relação de emprego, com as diretrizes gerais traçadas pela Lei 8.036/90.

As finalidades do FGTS no ordenamento jurídico brasileiro apresentamse bipartidas nos planos trabalhista e econômico-social, segundo a determinação constitucional e legal quanto ao destino e aplicação dos seus recursos.

No seu viés trabalhista o FGTS configura-se como crédito compensatório do tempo de serviço do trabalhador para albergá-lo diante de contingências legalmente previstas e servir como regime de indenização por sua dispensa arbitrária ou sem justa causa, no sentido da proteção do emprego.

De seu turno, no plano econômico-social o Fundo de Garantia revela-se como regime que dá suporte ao financiamento de programas sociais de habitação, saneamento básico e infraestruturas urbana e de base, promotores do desenvolvimento nacional e da geração de empregos. 
$\mathrm{Na}$ qualidade de instituto jurídico multifacetado o FGTS comporta uma plêiade de relações jurídicas subjacentes. A presente pesquisa cingiu-se às análises e reflexões sobre as relações estabelecidas entre o trabalhador e o empregador, e entre o empregador e a União, relativamente à recuperação dos créditos do Fundo de Garantia do Tempo de Serviço, em busca da realização das suas finalidades.

A recuperação dos créditos do FGTS por meio das ações trabalhistas movidas em face do empregador no âmbito da Justiça do Trabalho revela que o interesse perseguido pelo trabalhador é a garantia do seu próprio crédito, com vistas a cobrar os valores pecuniários que lhe servirão de amparo nas hipóteses de levantamento legalmente previstas, como forma de compensação do seu tempo de serviço e como garantia da indenização por dispensa arbitrária ou sem justa causa.

No processo de recuperação dos créditos relativos ao FGTS pelo trabalhador por meio de ação trabalhista identificam-se pontos críticos que demandam intervenção para garantia da efetividade do sistema de cobrança.

Nesse sentido, não se pode admitir que a cobrança das contribuições para o Fundo de Garantia do Tempo de Serviço seja levada a efeito como verbas trabalhistas acessórias. A regra de que o acessório segue o principal merece uma releitura doutrinária diante da identificação do FGTS como um direito autônomo do trabalhador decorrente do contrato de trabalho, e não das verbas salariais que lhe servem de base de incidência. A Constituição Federal erigiu o FGTS à categoria de direito fundamental do trabalhador em seu artigo $7^{\circ}$, III, e a legislação ordinária determina expressamente que os créditos relativos ao FGTS gozam dos mesmos privilégios atribuídos aos créditos trabalhistas, consoante se extrai do artigo $2^{\circ}, \S 3^{\circ}$, da Lei 8.844/94.

Ainda no âmbito da cobrança pelo trabalhador dos seus créditos relativos ao FGTS impõe-se alteração interpretativa para afastar a dúplice realidade de tratamento quanto ao prazo prescricional para cobrança judicial dos créditos do Fundo de Garantia do Tempo de Serviço, revelada pela prescrição trabalhista bienal e quinquenal nas ações ajuizadas pelos trabalhadores, consoante Súmulas 206 e 362, do Tribunal Superior do Trabalho, e pela prescrição trintenária observada nos executivos fiscais ajuizados pela Fazenda Pública com o mesmo mister. 
A divergência interpretativa quanto ao prazo prescricional evidencia questão juridicamente inconciliável, diante da possibilidade de cobrança pelo Estado, administrativamente ou em execução físcal, dos mesmos créditos do FGTS, que à luz da Justiça do Trabalho já se encontra prescrito para o trabalhador, o que acarreta descrédito ao princípio da isonomia, desconsidera o privilégio à prescrição trintenária estabelecida pelo artigo $23, \S 5^{\circ}$, da Lei n. 8.036/90, bem como a própria finalidade do FGTS que com prazo prescricional elastecido, garante mais amplamente a compensação pelo tempo trabalhado.

Assim, sob o manto do princípio protetor, considerada a realidade fática da baixa incidência de ações trabalhistas ajuizadas durante a vigência do contrato de trabalho pela convicção da perda do emprego e tomado o FGTS como direito fundamental do trabalhador, a interpretação deve se pautar pela norma mais favorável, representada pela prescrição trintenária, independentemente da prescrição das correlatas verbas trabalhistas que lhe dão suporte, seja o crédito perseguido pelo trabalhador ou pelo Estado, qualquer que seja o órgão do Poder Judiciário competente.

Também para evitar a inconsistência do modelo de recuperação dos créditos relativos ao FGTS pelo trabalhador impõe-se que a Justiça do Trabalho cumpra a obrigatoriedade legal da notificação à Caixa Econômica Federal e ao Ministério do Trabalho sobre o ajuizamento da correspondente ação trabalhista, cumulando, por interpretação extensiva do dispositivo do parágrafo único, do artigo 25, da Lei 8.036/90, a notificação quanto à decisão judicial condenatória, no sentido de evitar a propositura de execução fiscal pela Procuradoria-Geral da Fazenda Nacional para cobrança paralela dos mesmos créditos e prevenir a existência de decisões díspares em torno do mesmo objeto em juízo.

Por sua vez, o processo de recuperação dos créditos do FGTS promovido pela União, desenvolvido no âmbito administrativo e judicial, fundamenta-se na concretização das finalidades trabalhista e econômico-social do Fundo de Garantia, uma vez que visa a garantir, mediante fiscalização e autuações, o cumprimento da legislação relativa ao FGTS pelo empregador, bem como a arrecadar os recursos do FGTS para fazer face ao financiamento de programas sociais de habitação, saneamento básico e infraestruturas urbana e de base, como fatores ligados à promoção do desenvolvimento nacional e geração de empregos. 
A recuperação dos créditos do FGTS sob a ótica do vínculo entre o empregador e a União também apresenta pontos críticos que reclamam reformas em busca de efetividade.

Inicialmente aponta-se para necessária unidade da representação judicial na condução dos processos de execução fiscal dos créditos do FGTS relativos às contribuições mensais e rescisórias, em prol da harmonia na condução dos processos judiciais de recuperação dos créditos dos trabalhadores, tanto na construção de argumentos em linha unívoca de defesa nos Tribunais, quanto na eficácia das constrições de bens e alienações judiciais.

Essa providência demanda revogação do convênio de delegação de representação judicial, firmado entre a Procuradoria-Geral da Fazenda Nacional e a Caixa Econômica Federal, nos termos do artigo $2^{\circ}$ da Lei 8.844/94, para afastar o dualismo na legitimação processual para a cobrança dos créditos do FGTS relativos às contribuições mensais e rescisórias e evitar prejuízo à harmonia na defesa dos interesses do Fundo de Garantia do Tempo de Serviço quanto à recuperação dos correspondentes créditos devidos pelos empregadores. A especialização da Procuradoria-Geral da Fazenda Nacional para as execuções fiscais aliada à sua competência privativa para inscrição em dívida ativa e emissão do título executivo dos créditos relativos ao FGTS deve se sobrepor ao papel de agente operador exercido pela Caixa Econômica Federal quanto à tarefa de representação judicial do Fundo de Garantia, em prol da harmonia na condução dos processos judiciais de cobrança e para evitar intercorrências prejudiciais à efetiva recuperação dos créditos.

Para consistência da cobrança dos créditos do FGTS pela União apontase também a necessidade de se abolir a prática de pagamento dos créditos relativos ao FGTS diretamente ao trabalhador em ações trabalhistas. A prática de pagamento realizado diretamente ao trabalhador em ação trabalhista desconsidera que as verbas de FGTS perseguidas em ação trabalhista nem sempre poderiam ser levantadas de imediato pelo trabalhador por ausência de hipótese legal de saque, e além de ilegal pode ensejar a cobrança dos mesmos créditos pela União em duplicidade, acarretando sérios impactos processuais e aos cofres públicos. Para tanto deve ser obedecido o comando da Lei 8.036/90, no sentido de que os valores relativos ao FGTS devem ser depositados na conta vinculada do trabalhador, sejam recolhimentos espontâneos ou decorrentes de condenação judicial. 
Por fim, há necessidade premente de se suprimir a dicotomia de competências jurisdicionais do modelo de recuperação judicial dos créditos do FGTS pela União.

De se registrar que existem duas categorias de créditos relativos ao Fundo de Garantia do Tempo de Serviço objetos de recuperação judicial pela União. Uma categoria se compõe das multas aplicadas em relação ao descumprimento da legislação relativa ao FGTS, com fulcro no artigo 23, da Lei 8.036/90. A outra categoria é composta pelos créditos dos trabalhadores decorrentes das contribuições legais mensais e rescisórias devidas pelos empregadores, a serem depositados nas contas vinculadas individuais.

A recuperação dos créditos das multas punitivas aplicadas pela fiscalização do trabalho relativas ao FGTS, constituídas por meio de auto de infração, bem como a cobrança dos valores devidos às contas vinculadas dos trabalhadores, objetos de notificações fiscais também expedidas pela fiscalização do trabalho, seguem em juízo o procedimento da Lei de Execuções Fiscais e têm com título executivo extrajudicial a Certidão de Dívida Ativa. Todavia, quanto à competência jurisdicional para a execução dos mencionados créditos a vigente interpretação pretoriana do texto constitucional revela uma dualidade incompatível com a eficácia do modelo de sua recuperação.

Com efeito, a cobrança e discussão judicial em relação ao auto de infração e às notificações fiscais de recolhimento dos créditos do FGTS ocorrem de forma segregada, respectivamente na Justiça do Trabalho, com fundamento no inciso VII do artigo 114, da Constituição Federal, incluído pela Emenda Constitucional no 45/2004, e na Justiça Federal, com fundamento em interpretação do artigo 109, I, da Constituição Federal, dada pela Súmula 349, do Superior Tribunal de Justiça.

A unificação na Justiça do Trabalho da competência jurisdicional quanto à recuperação dos créditos do FGTS promovida pela Fazenda Pública Nacional é medida que se impõe, levados em consideração: a imprescindibilidade da relação laboral como pressuposto dos créditos do FGTS; a prevalência do critério material na determinação constitucional da competência de jurisdição; a prevalência do FGTS como direito fundamental do trabalhador em sua finalidade compensatória do seu tempo de serviço para albergá-lo diante de contingências legalmente previstas e servir como regime de indenização por sua dispensa arbitrária ou sem justa causa; a necessidade de se evitar 
competência concorrente entre os diversos ramos do Poder Judiciário, para prevenir a ocorrência de decisões conflitantes e insegurança jurídica; bem como a evidente inversão teleológica do modelo dicotômico de competência jurisdicional para a recuperação dos créditos do Fundo de Garantia, pois em que pese haver o interesse econômico-social perseguido pela União na cobrança dos valores das contribuições devidas ao FGTS perante a Justiça Federal, em ultima ratio seu destino é a conta vinculada para satisfação dos trabalhadores.

Diante desses fundamentos não se justifica a manutenção da interpretação literal do artigo 109, I, da Constituição Federal, quanto à competência da Justiça Federal ou dos juízes com competência delegada para o julgamento das execuções fiscais das contribuições devidas pelo empregador ao FGTS.

Em suma, a concentração no âmbito da Justiça do Trabalho referente à cobrança dos créditos do FGTS promovida pela União decorre do reconhecimento do Fundo de Garantia como direito fundamental do trabalhador, impondo-se mutação interpretativa quanto ao entendimento estampado na Súmula 349, do STJ. Registre-se que a Justiça do Trabalho integra a jurisdição federal e, sem descuidar de garantir a proteção aos direitos do trabalhador, acolhe perfeitamente o interesse fiscal e econômico-social da União quanto à arrecadação dos créditos do FGTS, a exemplo das execuções de ofício das contribuições previdenciárias decorrentes das sentenças trabalhistas, determinada pelo inciso VIII, do artigo 114, da Constituição Federal.

À evidência de todas as questões analisadas pela presente pesquisa e considerando que todo campo da realidade pode ser explorado a partir de muitos pontos de vista, e que a multiplicidade de enfoques ajuda a melhor compreendê-la ${ }^{107}$, conclui-se que o conjunto das medidas apontadas para sanar os pontos críticos identificados no modelo de recuperação dos créditos do FGTS promovida pelos trabalhadores e pela União pretende dotá-lo de efetividade, com vistas à consecução das finalidades do Fundo de Garantia do Tempo de Serviço sob seu viés de direito fundamental do trabalhador, consoante determinação constitucional.

\footnotetext{
${ }^{107}$ BOBBIO, Norberto. Teoria general del derecho. Trad. Jorge Guerrero R., Bogotá: Temis, 1992, p. XI (prólogo).
} 


\section{BIBLIOGRAFIA}

ALEXEY, Robert. Teoria de los derechos fundamentales. Trad. Ernesto Garzón Valdes. Madrid: Centro de Estúdios Constitucionales, 1997.

ALMEIDA, Amador Paes de. Curso prático de processo do trabalho. São Paulo: Saraiva, 2003.

ALVIM, José Eduardo Carreira. Elementos de teoria geral do processo. $6^{\mathrm{a}}$ ed. Rio de Janeiro: Forense, 1997.

ASSIS, Araken. Manual do processo de execução. $8^{\mathrm{a}}$ ed. São Paulo: Revista dos Tribunais, 2000 .

ATALIBA, Geraldo. Hipótese de incidência tributária. 5ª ed. São Paulo: Malheiros, 1993.

BARRETO, Amaro. Teoria e Prática do FGTS. São Paulo: Edições Trabalhistas, 1974.

BARROS, Alice Monteiro de. Curso de Direito do Trabalho. $5^{\text {a }}$ ed. São Paulo: LTr, 2009.

BARROSO, Luís Roberto. O direito constitucional e a efetividade de suas normas: limites e possibilidade da Constituição brasileira. Rio de Janeiro: Renovar, 1993.

BASTOS, Celso Ribeiro. Curso de direito constitucional. São Paulo: Saraiva, 1998.

BELTRAN, Ari Possidonio. Dilemas do trabalho e do emprego na atualidade. São Paulo: LTr, 2001.

BOBBIO, Norberto. A era dos direitos. Rio de Janeiro, Campus, 1992.

Teoria general del derecho. Trad. Jorge Guerrero R. Bogotá: Temis, 1992.

BONAVIDES, Paulo. Curso de direito constitucional. 12a ed. São Paulo: Malheiros, 2002.

CABANELLAS, Guillermo. Compendio de derecho laboral. v.2. Buenos Aires: Editores Libreros, 1968.

CALAMANDREI, Piero. Estudo de Direito Processual na Itália. Campinas: LZN Editora, 2003.

CAMPO, Santiago Pereira. El proceso laboral em Uruguay. Disponível em: $<$ http://www.uv.es/ ripj/11sant2.htm> Acesso em: 12 set. 2010. 
CANARIS, Claus Wilhem. Pensamento sintético e conceito de sistema na ciência do direito. Lisboa: Calouste, 1996.

CARDONE, Marly Antonieta. Contribuições para o FGTS nas conciliações de litígios. In IOB-Repertório de Jurisprudência: trabalhista e previdenciário. no 24, p. 670-667. São Paulo, 2002.

. Empregador em débito com o FGTS. In IOB-Repertório de Jurisprudência: trabalhista e previdenciário. $\mathrm{n}^{0}$ 7, p.137-9. São Paulo, 1999.

CARNEIRO, Athos Gusmão. Jurisdição e competência. 14ª ed. São Paulo: Saraiva, 2005. CARNELUTTI, Francesco. Sistema de direito processual civil. São Paulo: Classic Book, 2000 .

CARRION, Valentin. Comentários à Consolidação das Leis do Trabalho. 32a ed. São Paulo: Saraiva, 2007.

CARVAlHO, Paulo de Barros. Curso de direito tributário. $12^{\mathrm{a}}$ ed. São Paulo: Saraiva, 1999.

CARVALHO, Suzete. A tríade de considerações sobre o FGTS. LTr: legislação do trabalho. suplemento trabalhista. v.29, nº 55, p.361-2. São Paulo,1993.

CHIOVENDA, Giuseppe. Instituições de direito processual civil. v.2. Campinas: Bookseller, 1998.

CINTRA, Antônio Carlos de Araújo; GRINOVER, Ada Pellegrini; DINAMARCO, Cândido Rangel. Teoria geral do processo. 13º ed. São Paulo: Malheiros, 1997.

COLOMBO FILHO, Cassio. A multa do artigo 22, da lei do FGTS. Revista do Tribunal Regional do Trabalho da 9a Região. v.21. nº 2. p.119-24. Curitiba, 1996.

CORTEZ, Rita; CORDEIRO, Márcio Lopes. As ações judiciais para reposição da correção dos saldos do FGTS, em razão das perdas provocadas pelos planos econômicos e a proposta de adesão para pagamento desta dívida pelo governo federal. In LTr: legislação do trabalho. suplemento trabalhista. v.37. no 164. p. 785-790. São Paulo: LTr, 2001.

COUTINHO, Grijalbo Fernandes; FAVA, Marcos Neves; coordenadores. Nova competência da Justiça do Trabalho. São Paulo: LTr, 2005. 
CREMONESI, André. Marco inicial da prescrição nas ações trabalhistas quando se postula perante a Justiça Federal a diferenciada multa de 40 por cento sobre correção monetária expurgada da conta vinculada do FGTS em decorrência dos planos econômicos. In LTr: suplemento trabalhista. v.42. no 56. p.251-2. São Paulo: LTr, 2006.

CZAMARKA, Henrique. A intervenção do Instituto Nacional do Seguro Social - INSS, nas execuções trabalhistas, quanto ao FGTS. In LTr: suplemento trabalhista. v.43. $\mathrm{n}^{\mathrm{o}} 91$. p.383-385. São Paulo: LTr, 2007.

DALAZEN, João Orestes. Competência material trabalhista. São Paulo: LTr, 1994.

DELGADO, Maurício Godinho. Curso de direito do trabalho. São Paulo: LTr, 2006.

DINAMARCO, Cândido Rangel Dinamarco. A instrumentalidade do processo. $7^{\mathrm{a}}$ ed. São Paulo: Malheiros Editores, 1999.

. Instituições de direito processual civil. v. 4. São Paulo: Malheiros, 2004.

DONATO, Messias Pereira. Curso de Direito Individual do Trabalho. $6^{\mathrm{a}}$ ed. São Paulo: LTr, 2008.

DWORKIN, Ronald. Levando os direitos a sério. Trad. Nelson Boeira. São Paulo: Martins Fontes, 2002.

. O Império do Direito. Trad. Jefferson Luiz Camargo. São Paulo: Martins Fontes, 1999.

FERRANTE, Vera Lúcia Silveira Botta. FGTS: ideologia e repressão. São Paulo: Editora Ática, 1978.

FERRARI, Irany. Acordo coletivo de trabalho - renúncia de multa do artigo 477 da CLT multa de 40 por cento do FGTS. In LTr: suplemento trabalhista. v.43. n ${ }^{o} 104$, p.438. São Paulo: LTr, 2007.

FERREIRA FILHO, Manoel Gonçalves. Direitos Humanos Fundamentais. São Paulo: Saraiva, 1995.

FONTES, Paulo Gustavo Guedes. FGTS: obrigatoriedade da instituição do regime de conta única para cada trabalhador. In Boletim dos Procuradores da República. v.5. n. ${ }^{\circ} 65$. p.22-28. São Paulo, 2003. 
FRANCIULLI NETO, Domingos. Questões mais comuns argüidas em ações sobre o FGTS de competência da Justiça Federal. In Revista dos Tribunais. v.96. nº 858, p.729745. São Paulo, 2007.

GIGLIO, Wagner. Direito processual do trabalho. São Paulo: Saraiva, 1997.

GOMES CANOTILHO, José Joaquim. Direito constitucional e teoria da constituição. v. I. $4^{\mathrm{a}}$ ed. Coimbra: Coimbra Editora, 2007.

GOTTSCHALK, Elson. Natureza jurídica da indenização da lei do FGTS. In Revista LTr $38 / 819$.

GUERRA, Carlos Andre de Castro. FGTS: execução de sentença; obrigação de fazer a atualização monetária dos expurgos inflacionários reconhecidos e a aplicação dos juros capitalizados; verbas da sucumbência debitadas ao fundo. In Revista do Tribunal Regional Federal. 3ª Região. v. 40. p.100-1. São Paulo, 1999.

HÄBERLE, Peter. Hermenêutica constitucional: a sociedade aberta dos intérpretes da constituição: contribuição para a interpretação pluralistas e "procedimental" da Constituição. Trad. Gilmar Ferreira Mendes. Porto Alegre: Sérgio Fabris, 1997.

HABERMAS, Jürgen. A inclusão do outro - estudos de teoria política. $1^{\text {a }}$ ed. Trad. George Sperber and Paulo Astor Soethe. São Paulo: Edições Loyola, 2002.

HESSE, Konrad. A força normativa da Constituição. Trad. Gilmar Ferreira Mendes. Porto Alegre: Sérgio Fabris, 1991.

HOBSBAWM, Eric. Era dos extremos: o breve século XX, 1914-1991. Trad. Marcos Santarrita. São Paulo: Companhia das Letras, 2001.

JANTALIA, Fabiano. FGTS - Fundo de Garantia do Tempo de Serviço. São Paulo: LTr, 2008.

KELSEN, Hans. Teoria pura do direito. $4^{\mathrm{a}}$ ed. São Paulo: RT, 2006.

KUHN, Thomas S. A estrutura das revoluções científicas. $8^{a}$ ed. São Paulo: Perspectiva, 2003.

LALBA-LUZA, Guimarães de Mello. Da competência da Justiça do Trabalho em face da alteração introduzida pela Emenda Constitucional n ${ }^{\circ}$ 20/98. In Revista LTr. v.63, p. 469. São Paulo: LTr, 1999. 
LEITE, Cláudio Henrique Bezerra. Curso de direito processual do trabalho. São Paulo: LTr, 2006.

MACIEL, José Alberto Couto. FGTS: novas contribuições sociais; inconstitucionalidades e ilegalidades da lei complementar $n^{\circ}$ 110/2001. In Revista legislação do trabalho. v.65. n.8. p. 947-948. São Paulo: LTr, 2001.

MAGANO, Octávio Bueno. Manual de Direito Individual do Trabalho. São Paulo: LTr, 1986.

- Primeiras lições de Direito do Trabalho. $3^{\mathrm{a}}$ ed. São Paulo: Revista dos Tribunais, 2003.

; MALLET, Estêvão. O direito do trabalho na Constituição. Rio de Janeiro: Forense, 1993.

MANNRICH, Nelson. A modernização do contrato de trabalho. São Paulo: LTr, 1998. . CLT Legislação Trabalhista e Previdenciária. Constituição Federal. 8. ed. São Paulo: Revista dos Tribunais, 2007.

- Emenda constitucional 45 e as novas competências: da extinção ao fortalecimento da Justiça do Trabalho. In Revista de Direito do Trabalho. v. 31, n. 118. São Paulo, 2005.

. Inspeção do trabalho. São Paulo: LTr, 1991.

. Natureza, limites e finalidade da inspeção do trabalho. A justiça do trabalho e as ações relativas às penalidades administrativas. In Revista de Direito do Trabalho. v. 32. São Paulo: RT, 2006.

MANUS, Pedro Paulo Teixeira; ROMAR, Carla Teresa Martins; GITELMAN, Suely Ester. Competência da Justiça do Trabalho e EC no 45/2004. São Paulo: Atlas, 2006.

MARINONI, Luis Guilherme. Novas linhas do processo civil. $2^{\mathrm{a}}$ ed. São Paulo: Malheiros, 1999.

MARQUES, Frederico. Direito Processual do Trabalho. São Paulo: Atlas, 2002, p. 24.

MARTINS FILHO, Ives Gandra da Silva. A reforma do poder judiciário e seus desdobramentos na Justiça do Trabalho. In Revista LTR. v.1, n. 69. São Paulo: LTr, 2005. 
MARTINS, Ives Gandra da Silva; MARTINS, Rogério Vidal Gandra da Silva; LOCATELLI, Soraya David Monteiro. Natureza jurídica do FGTS e prazo prescricional: o FGTS possui natureza tributária; contrato de trabalho por prazo indeterminado; rescisão contratual e readmissão em curto prazo; unicidade contratual e fraude à lei; inteligência do artigo 104 do Código Civil; conduta sem boa-fé; indenização trabalhista (parecer). Revista do Tribunal Superior do Trabalho. v.68, n.1, p.85-105. Rio de Janeiro, 2002.

MARTINS, Melchíades Rodrigues. Lei $n^{o}$ 8.036/90, artigo 22: multa por atraso no reconhecimento do FGTS e a sua destinação. In LTr: suplemento trabalhista. v.39. n.68, p. 311-313. São Paulo, 2003.

MARTINS, Sérgio Pinto. Direito Processual do Trabalho. São Paulo: Atlas. 2004. Execução da contribuição previdenciária na justiça do trabalho. São Paulo: Atlas, 2001.

. Manual do FGTS. São Paulo: Atlas, 2006.

MAXIMILIANO, Carlos. Hermenêutica e aplicação do direito. Rio de Janeiro: Forense, 1984.

MEIRELLES, Hely Lopes. Direito administrativo brasileiro. $26^{\text {a }}$ ed. São Paulo: Malheiros, 2001.

MELEGA, Luiz. Fundo de garantia do tempo de serviço FGTS. Alterações, direito e obrigações do empregador, prazo prescricional. In Revista LTr: legislação do trabalho e previdência social. v.54, no 6, p. 646-649. São Paulo: LTr, 1990.

MELLO, Ialba-Luza Guimarães de. Da competência da Justiça do Trabalho em face da alteração introduzida pela Emenda Constitucional n. 20/98. In Revista LTr. v. 63, $\mathrm{n}^{\mathrm{o}}$ 4, p. 469-474. São Paulo: LTr, 1999.

MENEZES, Cláudio Armando Couce de. Teoria geral do processo e a execução trabalhista. São Paulo: LTr, 2003.

MORAES, Alexandre de. Direito constitucional. 16. ed. São Paulo: Atlas, 2004.

MOREIRA, José Carlos Barbosa. O novo processo civil brasileiro. 22. ed. Rio de Janeiro: Forense, 2002. 
NAHAS, Thereza Christina. Processo de conhecimento e de execução. São Paulo: LTr, 2004.

NASCIMENTO, Amauri Mascaro. Curso de direito processual do trabalho. $21^{\mathrm{a}}$ ed. São Paulo: Saraiva, 2002. . Iniciação ao Direito do Trabalho. 34ª ed. São Paulo: LTr, 2009.

OLIVEIRA, Fábio Leopoldo de. Curso expositivo de direito do trabalho. São Paulo: LTr, 1991.

OLIVEIRA, Francisco Antônio de. Comentários às Súmulas do TST. São Paulo: Revista dos Tribunais, 2007.

OLLIER, Pierre. Le droit du travail. Paris: Armand Colin, 1972.

PEREIRA, Caio Mario da Silva. Instituições de Direito Civil. Rio de Janeiro: Aide, 1987.

PEREIRA, Ricardo José Macedo de Britto. Ação civil pública trabalhista e FGTS. In Revista do Ministério Público do Trabalho. v.16, nº 31, p.110-8. Brasília, 2006.

PINTO, José Augusto Rodrigues. Curso de Direito Individual do Trabalho. São Paulo: LTr, 1995.

. Execução trabalhista: estática, dinâmica e prática. 10. ed. São Paulo: LTr, 2004. . Processo trabalhista de conhecimento. $7^{\mathrm{a}}$ ed. São Paulo: LTr, 2005.

PIOVESAN, Flávia. Direitos Humanos e o Direito Constitucional Internacional. $7^{\mathrm{a}}$ ed. São Paulo: Saraiva, 2006.

PITAS, José. FGTS: alguns pontos relevantes da nova Lei. In LTr: suplemento trabalhista. v.26, nº 98, p.483-484. São Paulo, 1990.

PLÁ RODRIGUEZ, Américo. Princípios de direito do trabalho. São Paulo: LTR, 1993.

PRADO, Roberto Barreto. Tratado de Direito do Trabalho. v. II. São Paulo: Revista dos Tribunais, 1971.

ROBERT, Margarida. Constituição da Organização Internacional do Trabalho. Lisboa: MQE. CICT, 1996.

ROMITA, Arion Sayão. Direitos fundamentais nas relações de trabalho. São Paulo: LTr, 2005. 
; GONÇALVES, Nair. (Org.). Curso de Direito do Trabalho: homenagem a Evaristo de Moraes Filho. São Paulo: LTr, 1983.

RUSSOMANO, Mozart Victor. Curso de Direito do Trabalho. 9a ed. Curitiba: Juruá Editora, 2009.

SAAD, Eduardo Gabriel. Comentários à Lei do Fundo de Garantia do Tempo de Serviço. São Paulo: LTr, 1995.

. Cobrança de contribuições sociais. In Revista LTr: suplemento trabalhista. v. 36, $n^{\circ}$ 131, p. 726. São Paulo: LTr, 2000.

SARLET, Ingo Wolfgang. A Eficácia dos Direitos Fundamentais. Porto Alegre, Livraria do Advogado, 2007.

SARMENTO, Daniel. A Ponderação de Interesses na Constituição Federal. Rio de Janeiro: Lumen Juris, 2000.

SILVA, Homero Batista Mateus da. Curso de Direito do Trabalho Aplicado. Rio de Janeiro: Elsevier, 2009.

SILVA, José Afonso da. Aplicabilidade das Normas Constitucionais. $7^{\mathrm{a}}$ ed. São Paulo: Malheiros, 2007.

Curso de direito constitucional positivo. São Paulo: Malheiros, 2006.

SÜSSEKIND, Arnaldo; MARANHÃO, Délio; VIANNA, Segadas; TEIXEIRA, Lima. Instituições de direito do trabalho. 19a ed. São Paulo: LTr., 2002.

TAVARES, Alexandre Macedo. A natureza tributária das contribuições do FGTS e a lei complementar $n^{\circ}$ 110/01. In Revista Dialética de Direito Tributário. $\mathrm{n}^{\circ}$ 73, p.7-20. São Paulo: Dialética, 2001.

TEIXEIRA FILHO, Manoel Antônio. A sentença no processo do trabalho. $3^{\mathrm{a}}$ ed. São Paulo: LTr, 2004.

. Breves comentários à reforma do poder judiciário. São Paulo: LTr, 2005. Execução no processo do trabalho. $7^{\mathrm{a}}$ ed. São Paulo: LTr, 2001.

THEODORO JÚNIOR, Humberto. Curso de direito processual civil. v.1. $29^{\mathrm{a}}$ ed. Rio de Janeiro: Forense, 1999. 
TORRES, Manuela Ramos. El fondo de garantia salarial: configuración y analisis de su regimén juridico sustantivo. Granada: Comares, 2000.

VIANA, Marcio Tulio. Prescrição do FGTS: trintenária ou quinquenal? In IOBRepertório de Jurisprudência: trabalhista e previdenciário. no 2. p.40-39. São Paulo, 1999. 